\title{
The Use of Concentration of Anti-Mullerian Hormone (AMH) as an Indicator of Reproductive Performance in Livestock Species
}

\author{
Adam Karl Russell Redhead
}

Follow this and additional works at: https://researchrepository.wvu.edu/etd

\author{
Recommended Citation \\ Redhead, Adam Karl Russell, "The Use of Concentration of Anti-Mullerian Hormone (AMH) as an Indicator \\ of Reproductive Performance in Livestock Species" (2017). Graduate Theses, Dissertations, and Problem \\ Reports. 6489.
}

https://researchrepository.wvu.edu/etd/6489

This Dissertation is protected by copyright and/or related rights. It has been brought to you by the The Research Repository @ WVU with permission from the rights-holder(s). You are free to use this Dissertation in any way that is permitted by the copyright and related rights legislation that applies to your use. For other uses you must obtain permission from the rights-holder(s) directly, unless additional rights are indicated by a Creative Commons license in the record and/ or on the work itself. This Dissertation has been accepted for inclusion in WVU Graduate Theses, Dissertations, and Problem Reports collection by an authorized administrator of The Research Repository @ WVU.

For more information, please contact researchrepository@mail.wvu.edu. 
The Use of Concentration of Anti-Mullerian Hormone (AMH) as an Indicator of Reproductive Performance in Livestock Species

Adam Karl Russell Redhead

Dissertation submitted

To the Davis College of Agriculture, Natural Resources and Design

At West Virginia University

In partial fulfillment of the requirements for the degree of

Doctor of Philosophy in

Animal and Food Science

\author{
Marlon Knights, Ph.D., Chair \\ Ida Holaskova, Ph.D. \\ Joe Moritz, Ph.D. \\ Kevin Shaffer, Ph.D. \\ Mathew Wilson, Ph.D.
}

Division of Animal and Nutritional Sciences

Morgantown, West Virginia
2017

Keywords: Anti-mullerian hormone, fertility, sheep, water buffalo, superovulation Copyright 2017 Adam Karl Russell Redhead 


\begin{abstract}
The Use of Concentration of Anti-Mullerian Hormone (AMH) as an Indicator of Reproductive Performance in Livestock Species
\end{abstract}

\title{
Adam Karl Russell Redhead
}

Reproductive success is essential for high levels of animal productivity. Low fertility has been identified as one of the main constraints hindering the productivity of livestock systems. To address this problem, several tools such as genomic selection and assisted reproductive techniques (ART) have been implemented. Two of the more common ART used to improve reproductive performance are artificial insemination (AI) and embryo transfer (ET). The success of these methods is highly dependent on individual animal characteristics; therefore the ability to select animals that provide high levels of reproductive success is essential. The size of the ovarian antral follicular population (AFP) is directly determined by the antral follicular count (AFC) and can help determine reproductive success in sheep and success in ART in water buffaloes. The circulating levels of anti-mullerian hormone (AMH) have been found to be associated with AFP and may be an important endocrine marker in selection of females of high reproductive potential. In study 1, the effect of breed on AMH and the relationship between AMH and fertility in replacement ewes was evaluated. Katahdin females had a higher A than Dorset/Texel (DT) and Suffolk females. Katahdin females with HIGH AMH had a higher conception rate and lambing to first service than females with LOW AMH. AMH did not affect conception rate and lambing to first service in DT females. Katahdin females that conceived and lambed to the first service had a higher concentration of AMH. Concentration of AMH did not differ among DT females. In study 2, the concentration of $\mathrm{AMH}$ and the relationship between $\mathrm{AMH}$ and age, follicular growth and development in water buffaloes was evaluated. The within cow repeatability of the concentration of AMH was 0.97. AMH generally increased until ten years of age and then decreased. The mean concentration of AMH was 194 pg/ml. Females with HIGH AMH had more large follicles and follicles with a greater diameter than females with LOW AMH. In study 3, the relationship between circulating $\mathrm{AMH}$ and type of FSH preparation (FSHp and Folltropin) on follicular growth and development and ovulatory response in water buffaloes was evaluated. In animals treated with FSHp, HIGH systemic AMH was associated with more small follicles. AMH had no effect on small follicles in animals treated with Folltropin V. In animals treated with Folltropin V, HIGH AMH was associated with a higher ovulation rate. AMH had no effect on the number of ovulated follicles in animals treated with FSHp. These studies provide evidence that AMH varies among breeds of sheep, with age in water buffaloes and may be a reliable endocrine marker to predict ovarian response to superovulation treatments in water buffaloes. 


\section{ACKNOWLEDGEMENTS}

I hereby formally thank my advisor Dr. Marlon Knights for providing the opportunity for me to pursue this degree program. His leadership, patience, guidance and support were critical to my progress throughout the program. I will forever be thankful for his contributions toward my conceptualization of a philosophy of animal science research. I would also like to thank the other members of my committee, Drs. Ida Holaskova, Joe Mortiz, Kevin Shaffer and Mathew Wilson for their assistance in improving my ability to think in the field of Animal Science. The assistance of the minority scholars program (known as the Chancellors Scholars Program) was immeasurable and thus I will forever be thankful to the Division of Diversity, Equity and Inclusion.

To my dear parents, Dr. Carol Andrews Redhead and Mr. Iram Redhead, I want to express my sincere appreciation and thanks for the support you have given me over the years and for always reminding me that perseverance and hard work leads to success, and that success is permanent without destroying your principles.

Sincere appreciation is also extended to my fellow graduate students, Kellie Branson, Stephanie Simpson, Calli Paul, Kyle Powell, Erin Greenleaf, Abiodun Adebiyi, Sarah Carr, Ashleigh Nabers, Alana Cuffi for the academic and nonacademic experiences shared. I would also like to thank Dr. Quinn Baptiste who in the early stages provided an atmosphere conducive to academic advancement.

I would like to thank the administrative staff, Mrs. Lindsay Triplet, Mrs. Bonnie Wood, Mrs. Kim Mouser and Mrs. Gretchen Riggs for helping me with the administrative aspects of my projects.

Finally, I would like to thank Jerry Yates, Chestina Merriner, Reymann Memorial Farm staff, George and Lisa Wherry, James Dean and Aripo Livestock Station (Trinidad and Tobago) for their contribution to the completion of this project. I thank them all for their various contributions. 


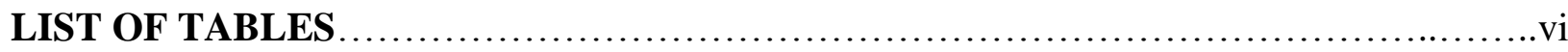

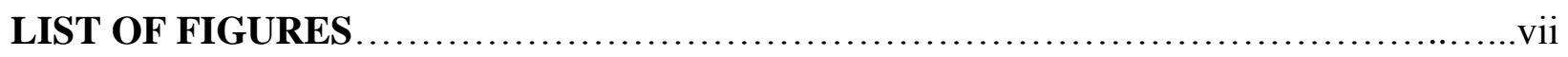

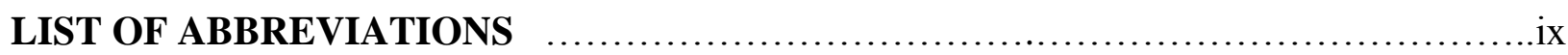

CHAPTER 1 STATEMENT OF PROBLEM ....................................................................................... 1

CHAPTER 2 LITERATURE REVIEW .............................................................................................. 5

Anti-Mullerian Hormone (AMH) ............................................................................... 7

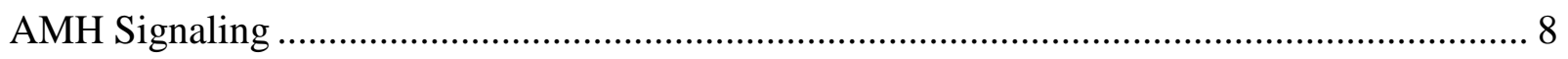

Expression of AMH and its receptors in the ovary …….................................................... 9

Regulation of AMH Expression ...................................................................................... 10

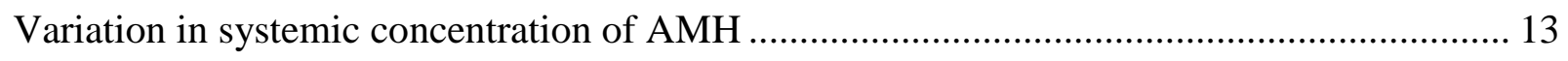

Systemic Concentration of AMH............................................................................... 13

Variation in concentration of AMH within and among breeds ....................................... 13

Variation in concentration of AMH during the Estrous Cycle .......................................... 14

AMH effects on follicle development in the ovary ............................................................ 15

Early Follicular Development and Cyclic Recruitment of Follicles and Ovulation ........ 15

AMH and Folliculogenesis .................................................................................. 20

AMH and FSH action .......................................................................................... 21

AMH and antral follicular population (AFP) .................................................................... 22

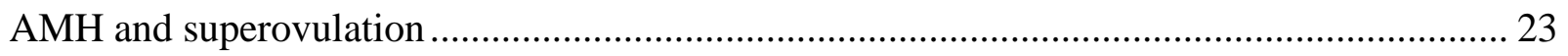

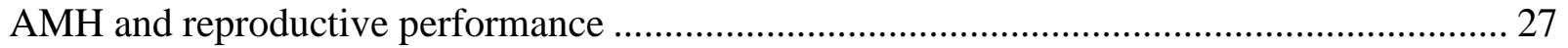

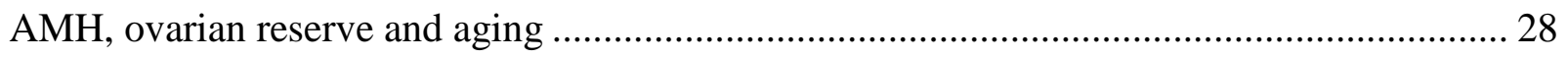

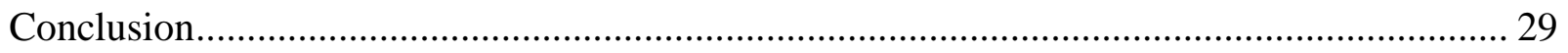


CHAPTER 3 THE RELATIONSHIP BETWEEN THE CONCENTRATION OF AMH AND FERTILITY IN REPLACEMENT FEMALES............................................................31

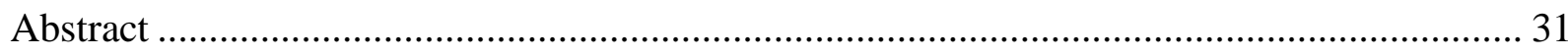

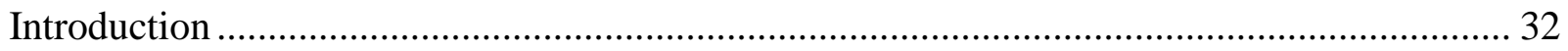

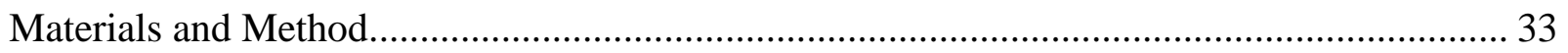

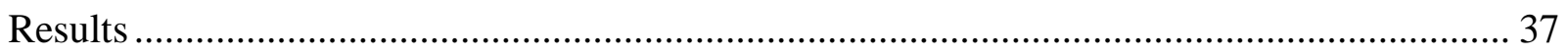

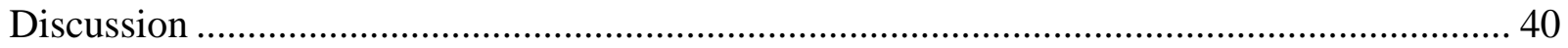

CHAPTER 4 THE RELATIONSHIP BETWEEN THE CONCENTRATION OF AMH, AGE AND FOLLICLE GROWTH AND DEVELOPMENT IN WATER BUFFALOES

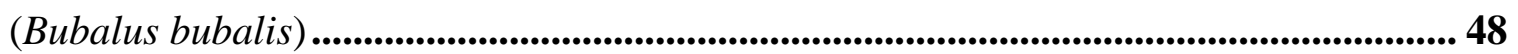

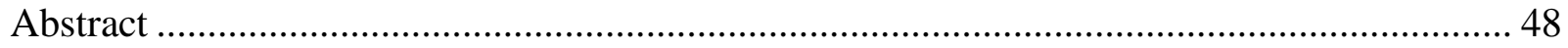

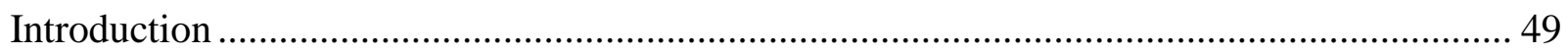

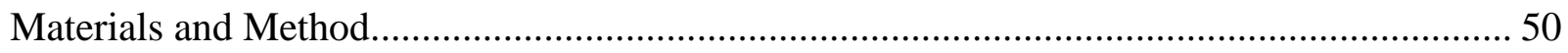

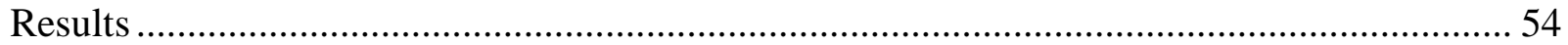

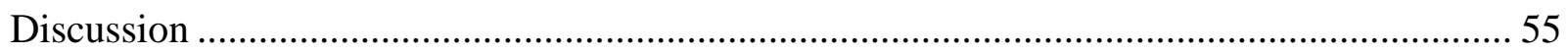

CHAPTER 5 THE EFFECT OF CIRCULATING CONCENTRATION OF AMH AND TYPE OF FOLLICLE STIMULATING HORMONE (FSH) ON FOLLICLE GROWTH OVULATORY RESPONSE TO SUPEROVULATION IN WATER BUFFALOES

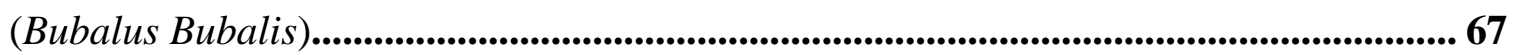

Abstract ..w.

CHAPTER 6 SUMMARY AND GENERAL CONCLUSIONS ...................................................... 87

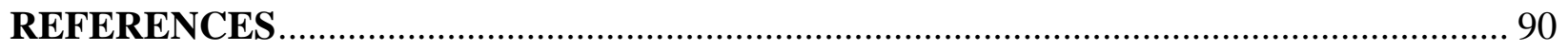

VITA 


\section{LIST OF TABLES}

Table 3.1. Concentration of AMH used to classify animals as low, medium and high and total number of animals for experiment 1 and experiment 2

Table 3.2. Effect of breed (Dorset/Texel Crosses, $n=238$ and Katahdin, $n=77$ ) and concentration of AMH (Low, Medium and High) on reproductive responses of replacement females. 44

Table 3.3. Main effects of breed (Dorset/Texel crosses, $n=238$ and Katahdin, $n=77$ ) and concentration of AMH (Low, Medium and High) on reproductive responses of replacement females

Table 3.4. The relationship between concentration of $\mathrm{AMH}$ and reproductive responses in Dorset/Texel crosses $(n=238)$ and Katahdin breed $(n=77)$ ewe lambs. 46

Table 4.1. Effect of concentration of AMH (Low vs. High) on the characteristics of follicular growth and development in water buffaloes $(n=20)$ during the estrous cycle. 


\section{LIST OF FIGURES}

Figure 3.1. Effect of age on the concentration of AMH in (a) Dorset $(n=238)$ and (b) Katahdin $(n=77)$ replacement females. Each circle represents data from one ewe lamb.

Figure 4.1. Estrus synchronization protocol 60

Figure 4.2. Regression Plot of anti-Mullerian hormone (AMH) concentrations 6 months apart in 20 water buffaloes (Bubalus bubalis). 61

Figure 4.3. Regression of concentration of $A M H$ on age in water buffaloes (Bubalus bubalis, $n=$ 41) between the ages 0 to 22 years. 62

Figure 4.4. Growth and development of ovarian follicles, small $(3-5 \mathrm{~mm})$, medium $(5-10 \mathrm{~mm})$ and large $(>10 \mathrm{~mm}$ ) of water buffaloes (Bubalus bubalis, $\mathrm{n}=20)$ during the estrous cycle (Day $0=$ day of ovulation). 63

Figure 4.5. Average daily total numbers of follicles of water buffaloes (Bubalus bubalis, $n=20$ ) during the estrous cycle (Day $0=$ day of ovulation). 64

Figure 4.6. Effect of concentration of AMH (Low vs. High) on the average daily number of small $(3-5 \mathrm{~mm})$, medium $(5-10 \mathrm{~mm})$, large $(>10 \mathrm{~mm})$ follicles and total number of follicles in water buffaloes (Bubalus bubalis, $\mathrm{n}=20$ ) during the estrous cycle. 65

Figure 4.7. Effect of (a) concentration of AMH (Low vs. High) and (b) day on the largest diameter and second largest diameter of follicle of water buffaloes (Bubalus bubalis, $\mathrm{n}=$ 20) during the estrous cycle (Day of ovulation $=0$ ).. 66

Figure 5.1. Experimental Plan and Timeline 80

Figure 5.2. Growth and development of small $(3-5 \mathrm{~mm})$, medium $(5-10 \mathrm{~mm})$ and large $(>10$ $\mathrm{mm}$ ) ovarian follicles of water buffaloes (Bubalus bubalis, $\mathrm{n}=31$ ) treated to induce superovulation during the pre-ovulatory period.. 81 
Figure 5.3. Interaction of concentration of AMH (High and Low) and type of FSH preparation type (FSHp high LH content vs Follotropin low LH content) on the number of small (3-5 $\mathrm{mm}$ ) follicles during the pre-ovulatory period in water buffaloes (Bubalus bubalis, $\mathrm{n}=$ 31) treated to induce superovulation. 82

Figure 5.4. Effect of of concentrations of AMH (Low vs. High) on numbers of medium (5-10 $\mathrm{mm})$, large $(>10 \mathrm{~mm})$ and total follicles of water buffaloes (Bubalus bubalis, $\mathrm{n}=31$ ) during the pre-ovulatory period treated to induce superovulation. 83

Figure 5.5. Effect of type of FSH preparation (FSHp, high LH content vs Follotropin, low LH content) on numbers of medium $(5-10 \mathrm{~mm})$, large $(>10 \mathrm{~mm})$ and total follicles during the pre-ovulatory period in water buffaloes (Bubalus bubalis, $\mathrm{n}=31$ ) given treated to induce

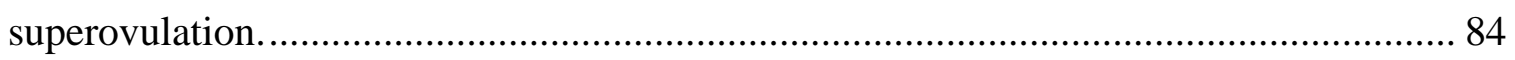

Figure 5.6. Effect of concentration of AMH (Low and High) and type of FSH preparation type (FSHp, high LH content and Follotropin, low LH content) on the number of large (> 10 $\mathrm{mm})$ follicles that disappeared in water buffaloes $(\mathrm{n}=31)$ treated to induce superovulation. 85

Figure 5.7. Effect of (a) concentration of AMH (Low vs. High concentrations) (b) FSH preparation type (FSHp high LH content vs. Follotropin low LH content) on the number of large $(>10 \mathrm{~mm})$ follicles that disappeared in water buffaloes $(\mathrm{n}=31)$ treated to induce superovulation. 86 


\section{LIST OF ABBREVIATIONS}

\begin{tabular}{|c|c|}
\hline $\mathrm{AFC}$ & Antral follicular count \\
\hline AFP & Antral follicular population \\
\hline AI & Artificial insemination \\
\hline ALK & Activin-like protein kinase \\
\hline $\mathrm{AMH}$ & Anti-Mullerian hormone \\
\hline AMHR & AMH receptor \\
\hline AMHRII & AMH type II receptor \\
\hline BMP & Bone morphogenetic protein \\
\hline CL & Corpus luteum \\
\hline $\mathrm{CP}$ & Crude protein \\
\hline CYP19 & Cytochrome $\mathrm{P} 450$ aromatase \\
\hline DF & Dominant follicle \\
\hline DT & Dorest/Texel \\
\hline ET & Embryo transfer \\
\hline FSH & Follicular stimulating hormone \\
\hline GCs & Granulosa cells \\
\hline GDF 9 & Growth differentiation factor 9 \\
\hline GLC & Granulosa lutein cells \\
\hline $\mathrm{GnRH}$ & Gonadotrophin-releasing hormone \\
\hline HCG & Human chorionic gonadotropin \\
\hline IGF & Insulin growth factor \\
\hline
\end{tabular}




\begin{tabular}{ll} 
IGFBPs & Insulin growth factor binding proteins \\
IVEP & In-vitro embryo production \\
LH & Luteinizing hormone \\
MIS & Mullerian inhibiting substance \\
OPU & Ovum pick up \\
PAPP & Pregnancy associated plasma protein \\
PG & Prostaglandin \\
pFSH & Porcine FSH \\
pLH & Porcine LH \\
SF-1 & Steroidogenic factor 1 \\
Sry & Sex determining region of the Y chromosome \\
TFP & Total factor productivity \\
TGF 3 & Transformation growth factor beta \\
WT-1 & Wilms tumor protein \\
& Zona pellucida glycoprotein 3 \\
\hline &
\end{tabular}




\section{CHAPTER 1}

\section{STATEMENT OF PROBLEM}

As animal scientists, we are faced with the challenge of meeting the growing demand for food. Enhancing and accelerating sustainable agricultural productivity is a central component of a comprehensive strategy to meet this demand. Productive efficiency (measure of output per unit of input) allows more food to be produced while maximizing the use of scarce resources. To improve productive efficiency, the producer may use three main strategies to increase their production yields, (1) expansion - using more land or extending irrigation to cropland so that it can be harvested frequently and protected from drought (2) intensification - using fertilizer, machinery, labor or other inputs on land used to grow crops or produce livestock and (3) adopting technologies and farming practices that result in more output from existing inputs or resources which is measured by total factor productivity (TFP). TFP is the ratio of agricultural outputs (crop and livestock output) to inputs (land, labor, fertilizer, feed, machinery and livestock). It measures the changes in efficiency with which inputs are transformed into outputs. The global population is increasing, resulting in the increasing demand for food, the efficiency with which inputs are transformed into outputs (TFP) needs to be increased. This is particularly true for developing economies and particularly tropical developing countries where natural resources are often limited.

Presently the livestock industry is one of the fastest growing sectors in the world and has the capability to meet the global demand for food in the form of protein. As global population and wealth increase, so will the demand for livestock products with the emphasis on highly nutritious products. Animal biotechnology is increasingly becoming a sustainable means of 
improving livestock productivity and has the potential to improve productivity via growth, carcass quality, reproduction, improved nutrition and feed utilization, improved food quality and safety, improved animal health and welfare of animals and reduced waste through more efficient utilization of resources (Ramli et al., 2011).

Reproductive success is essential for high levels of animal productivity. Conversely, reproductive failure is one of the most significant factors that limit the productivity of livestock systems and result in the loss of millions of dollars. To address this problem, several tools have been implemented using technologies such as genomic selection and assisted reproductive techniques (ART). Genomic selection has already been adopted by tropical dairy breeds (Zhang et al., 2013) and is being used together with ART to increase availability of improved cattle genetics (Garcia et al., 2013). In addition, ART has also been used to improve reproductive via artificial insemination (AI) and embryo transfer (ET) (Smidt et al., 1999; Vishwanath et al., 2003). The aim of these methods is to increase production, reproductive efficiency and rates of genetic improvement (Madan, 2005). Success via these methods comes from the ability to increase the production of offspring from selected females. The outcome of these methods is also highly dependent on the individual characteristics of the animal. Therefore, the ability to select animals with high levels of reproductive success following ART will improve the cost effectiveness of such techniques and make them more feasible in species that are better adapted to tropical developing states.

Water buffaloes are ideally suited for the production of meat and milk in developing countries (Rastogi et al., 2004). However, the rate of genetic improvement and widespread use of improved genetics has been limited due to high variability in reproductive outcomes following ART. Many of the super ovulatory protocols used in water buffalo have been developed based on 
research conducted in cattle (Madan et al., 1996). However, when compared to cattle, the superovulatory response is lower (Madan et al., 1996; Songasen et al., 1999; Techakumpu et al., 2000; Drost, 2007; Neglia et al., 2010, Li et al., 2011), which makes the use of embryo transfer procedures economically infeasible for water buffaloes. Due to the low and variable response to superovulation treatment in water buffaloes, the ability to select females that will show a high and repeatable response to superovulation treatments will be beneficial in attempts to collect, preserve, improve and use water buffalo genetic resources.

In cattle, the circulating concentrations of AMH have been found to be associated with and capable of predicting AFP (Ireland et al., 2008; Rico et al., 2009; Batista et al., 2014). In addition, the concentration of AMH can also predict the response to superovulation treatments in cattle (Monnaiux et al., 2010; Souza et al., 2014), goats (Monniaux et al., 2011) and sheep (Lahoz et al., 2014). Little data exist on the systemic concentration of AMH in water buffaloes, the correlation between the concentration of AMH and AFP and the relationship between the concentration of $\mathrm{AMH}$ and the superovulatory response. Variability in superovulation response has been linked to factors such as type of gonadotropins used in these treatments and age of the donor (Kafi et al., 1997). The effect of type of gonadotropin treatment, and age on superovulatory response in water buffaloes has not been fully examined.

Recently, the concentration of AMH has also been shown to be a useful tool to predict fertility in some livestock species. In cattle, the concentration of AMH in plasma was shown to be positively correlated with the maintenance of pregnancy post-AI (Ribeiro et al., 2014) and to be a predictor of longevity in the breeding herd (Jimenez-Krassel et al., 2015). In one study, using a single breed of sheep, the concentration of AMH measured at an early age was shown to be a predictor of fertility at first mating (Lahoz et al., 2012). In cattle it was reported that the 
concentration of AMH varies with breed (Batista et al., 2014; Baldrighi et al., 2014; Guerreiro et al., 2014; Stojsin - Carter et al., 2016); therefore, the relationship between the concentrations of $\mathrm{AMH}$ in replacement females might not be consistent across breeds of sheep. Furthermore, the use of $\mathrm{AMH}$ as a selection tool can reduce the associated cost with raising replacement females and the losses associated with involuntary culling of breeding females as a result of reproductive failure. Limited data exist on the use of concentration of AMH to predict fertility across different breeds in sheep.

Therefore the objectives of these studies are:

(1) To evaluate the concentration of $\mathrm{AMH}$ of different breeds of replacement ewes.

(2) To determine if the relationship between the concentration of AMH and fertility varies with breed in replacement ewes.

(3) To determine the concentration of $\mathrm{AMH}$ in water buffaloes and its relationship to age, pattern of growth and development of follicles in water buffaloes.

(4) To determine the relationship between circulating concentrations of AMH and type of FSH preparation on follicular growth and development and ovulatory response in water buffaloes. 


\section{CHAPTER 2}

\section{LITERATURE REVIEW}

Livestock systems occupy approximately $30 \%$ of the world's ice free terrestrial surface area (Steinfeld et al., 2006) and provides employment for the minimum of 1.3 billion people globally while directly supporting the livelihoods of approximately 600 million poor farmers in the developing world (Thorton et al., 2006; 2010). Rosegrant et al. (2009) reported that livestock products contribute 17 and 33 percent to global calorie and protein consumption, respectively.

Presently, the livestock industry is one of the fastest growing sectors in developing countries. This growth is as a result of the rapid demand for livestock products driven by population growth, urbanization and increasing incomes. The population of the world in 2050 is projected to be 9.15 billion (Alexandratos et al., 2012). Approximately one sixth of the global population currently does not meet their daily nutritional demand (Canadian International Developmental Agency, 2013). As both global population and wealth increase, so will the demand for livestock products. Competition for land and water resources from other industries will also intensify, necessitating more efficient livestock production systems (Hayes et al., 2013).

Animal biotechnology is increasingly becoming a sustainable means of improving livestock productivity and has the potential to improve growth, carcass quality, reproduction, improved nutrition and feed utilization, improved food quality and safety, improved animal health and welfare and reduced waste through more efficient utilization of resources (Ramli et al., 2011). Efficient reproduction is of utmost importance for the sustainable improvement of animal productivity and is a critical factor influencing the economic viability of livestock farmers. Low fertility is often identified as one of the primary constraints hindering the 
efficiency of livestock production systems. Assisted reproductive technologies (ART) provide a means whereby reproductive performance may be improved (Shelton et al., 1990; Kahi et al., 2008; Choudhary et al., 2016). Two common methods of ART are artificial insemination (AI) and embryo transfer (ET) (Smidt et al., 1999). The main aim of these methods is to increase production, reproductive efficiency and rates of genetic improvement (Madan, 2005). Assisted reproductive technologies (ART) have been introduced to overcome reproductive problems. The success of these techniques is highly dependent on the individual physiological characteristics of the animal such as the ovarian antral follicle population (AFP). As a result of this, the efficiency of these ART technologies can be compromised by the large variability of AFP among donor animals. Therefore, selection of animals for use in these techniques is of great importance.

Two primary selection tools are evaluating the genome of the animal and the use of endocrine markers. Genomic selection has already been adopted by dairy industries worldwide and is expected to double genetic gains for milk production and other traits (Thomasen et al., 2016; Henryon et al., 2014). In the last decade, the use of endocrine markers in selection has increased including the use of endocrine markers for determination of AFP. The pool of healthy oocytes and ovaries (the ovarian reserve) is highly variable at birth and the number of oocytes, follicles and their quality decrease rapidly with age in humans (Gougeon et al., 1994), cattle (Erickson et al., 1966), sheep (Steckler et al., 2005) and swine (Black et al., 1968). Endocrine markers together with ultrasound techniques have been used to estimate the ovarian reserve. Indirect markers of AFP include concentrations of follicle stimulating hormone (FSH) (Burger et al., 2002; Caroppo et al., 2006; Roudebush et al., 2008; Kahapola Arachchige et al., 2012), luteinizing hormone (LH) (Noci et al., 1998; Shrim et al., 2006; Brodin et al., 2009; Chun et al., 2014), estradiol (Smotrich et al., 1995; Evers et al., 1998; Mikkelsen et al., 2001) and FSH to LH 
ratio (Mukherjee et al., 1996; Perloe et al., 2000; Liu et al., 2008). Direct markers of AFP include the concentration of inhibin B (Seifer et al., 1997; 1999; Muttukrishna et al., 2004) and the concentration of Anti-mullerian hormone (AMH). Recently, the circulating concentration of AMH has been found to be associated with AFP (Ireland et al., 2008; Rico et al., 2009; Batista et al., 2014) and identified as an important endocrine marker of superovulation response (Rico et al. 2009; Monnaiux et al., 2010; Souza et al., 2014) and in-vitro embryo production (IVEP) in cattle (Gamarra et al., 2014; Guerreiro et al., 2014; Vernunft et al., 2015). In addition, some authors have suggested using AMH to predict fertility (Ribeiro et al., 2014) and herd longevity (JimenezKrassel et al., 2015) in cattle.

\section{Anti-Mullerian Hormone (AMH)}

Anti-Mullerian hormone or mullerian inhibiting substance (MIS) is the factor which forms the basis of the uterus, oviducts and upper part of the vagina (Jost, 1947; Munsterberg et al., 1991). It is a 140-kDa dimeric glycoprotein hormone which belongs to the transforming growth factor- $\beta$ (TGF- $\beta$ ) family (Cate et al., 1986). The isolation and characterization of the human AMH gene showed that the gene consists of five exons and maps to chromosome 19 (Cate et al., 1986; Picard et al., 1986). AMH is generated as a large precursor with a short signal sequence. This is followed by the prohormone which forms homodimers (Zec et al., 2011). Before secretion, the mature hormone undergoes glycosylation and dimerization to produce a $144 \mathrm{k}-\mathrm{Da}$ dimer which is comprised of disulphide linked $72 \mathrm{kDa}$ monomer sub units (Zec et al., 2011). Each monomer contains an $\mathrm{N}$ terminal domain and a $\mathrm{C}$ terminal domain called the pro and mature regions, respectively (Pepinsky et al., 1988; Wilson et al., 1993). It was suggested that the $\mathrm{N}$ terminal domain controls the activity of the $\mathrm{C}$ terminal domain and is responsible for 
the biological activity of the molecule. As AMH is transported through the cytoplasm, approximately 5 to $20 \%$ of the prohormone $\mathrm{AMH}$ is cleaved at a specific site between the $\mathrm{N}$ and $\mathrm{C}$ terminal domains of the $72 \mathrm{kDa}$ monomer to form two polypeptides, $58 \mathrm{kDa}$, the pro region, and $12 \mathrm{kDa}$, the mature region (Pepinsky et al., 1988; Wilson et al., 1993).

\section{AMH Signaling}

Since AMH is a member of the TGF- $\beta$ family, it was thought that AMH signals through a serine-threonine kinase receptor complex consisting of ligand specific type II receptors and more general type I receptors, also known as activin receptor like protein kinases (ALKS) (Visser et al., 2005; Massaque et al., 1990). With respect to AMH, AMH type II receptor (AMHRII) has been identified (Baarends et al., 1995) and shown to be involved in the signaling process (Mishina et al., 1996; Durlinger et al., 2002a). Jamin et al. (2002) reported that BMPr1a (Bone morphogenetic protein receptor type $1 \mathrm{~A}$ ) is a type 1 receptor for $\mathrm{AMH}$ induced regression of the Mullerian ducts which suggests that $\mathrm{AMH}$ uses the same pathway as the BMP (Bone Morphogenetic Protein) family (Jamin et al., 2002; Visser et al., 2014). Three BMP type 1 receptors ALK2, ALK3 and ALK6 have been shown to be associated with AMH type 1 receptors. Visser et al. (2001) reported that in an in vitro mullerian duct regression assay, treatment with antisense ALK2 inhibited AMH induced regression. Gouedard et al. (2000) reported the co-immunoprecipitation of known type 1 receptors with different AMH type 2 (AMHRII) receptors and ALK6 was the only type I receptor interacting in a ligand-dependent manner with AMHRII. This study also revealed that AMH activates the smad 1 pathway. In 
contrast, Clarke et al. (2001) reported that ALK6 functions as an AMHR1, but on examination of ALK6 null mice, no abnormalities in mullerian duct regression occurred.

\section{Expression of AMH and its receptors in the ovary}

In females, $\mathrm{AMH}$ is only expressed postnatally in the ovary. The mRNA and protein exist in the granulosa cells of preantral and small antral follicles of both rat and mouse (Hirobe et al., 1992; Durlinger et al., 2002b; Baarends et al., 1995). However, the pre-granulosa cells of primordial follicles do not express AMH. Granulosa cell expression occurs during a specific window of folliculogenesis shortly after the primordial follicle begins to grow (Taketo et al., 1993; Baarends et al., 1995; Durlinger et al., 2002; Seifer et al., 2007). AMH concentration varies during the growth of the follicle and occurs at low levels in primary follicles, increases to a maximum concentration in large preantral and small antral follicles (Salmon et al., 2004; Grondahl et al., 2011) and declines as the follicles grows further (Durlinger et al., 2002b). Immunohistochemical studies of $\mathrm{AMH}$ in human granulosa cells showed that the highest expression was found in follicles with a diameter of less than $4 \mathrm{~mm}$ and decreased during the later stages of follicle development (Weenen et al., 2004; Visser et al., 2006). Intrafollicular concentrations of AMH become progressively lower with increasing follicular diameter (Andersen et al., 2010).

$\mathrm{AMH}$ is expressed in rat preovulatory follicles (Ueno et al., 1989; Hirobe et al., 1994) and is a unique factor that promotes preantral follicle growth but not preantral follicle cell differentiation (McGee et al., 2001). AMH expression disappears when a follicle becomes atretic (Baarends et al., 1995; Durlinger et al., 2002a) and is not expressed in the theca cells, oocytes 
and interstitial cells of the ovary (Hirobe et al., 1994; Baarends et al., 1995; Durlinger et al., 2002a).

In contrast to $\mathrm{AMH}$, the AMHRII is found in the Mullerian duct mesenchymal cells and sertoli cells in the testes of the male and granulosa cells of the female (di Clemente et al., 1994; Baarends et al., 1995). AMHRII expression occurs in the same areas where AMH in the granulosa is expressed in the postnatal ovary of mice and rats (Baarends et al., 1995). The AMH type I receptor (AMHRI) is expressed in the fetal and adult mouse ovaries, however, ALK6 is not expressed in the ovaries of mouse fetuses (Visser et al., 2001). ALK6 is expressed in the oocytes of small and large antral follicles and in the granulosa cells of large antral follicles and does not co-localize with the AMHRII (Yi et al., 2001).

In cattle, the cumulus cells and the outer layers of the granulosa cells close to the theca are preferred areas of high concentrations of AMH expression in healthy antral follicles (Rico et al., 2011). AMH expression is strongly diminished in atretic follicles, except in the cumulus cells surrounding the oocyte (Rico et al., 2011).

\section{Regulation of AMH Expression}

Several factors that are involved in sex determination and differentiation appear to be important in the regulation of AMH expression. Sry (sex determining region of the $\mathrm{Y}$ chromosome) is a transcription factor encoded by the Sry gene located on the Y chromosome and can cause an increase in $\mathrm{AMH}$ promoter activity. Sequences within $2 \mathrm{~kb}$ of the AMH promoter region are sufficient for granulosa cell specific expression and sertoli cell specific expression (Peschon et al., 1992). To support this conclusion, Shen et al. (1994) and Dresser et 
al. (1995) used deletion analysis to demonstrate that regulating sequences are contained within the most proximal 180bp of the AMH 5' flanking region. Further, a Sry binding region has been identified in the AMH promoter (Haqq et al., 1994).

Besides the Sry binding, a second putative element was identified in the AMH promoter which is known as the AMH-RE-1. This 20 bp AMH-RE-1 contains a motif that resembles the half site for a number of nuclear hormone receptors (Shen et al., 1994). SF-1 (Steroidogenic factor 1) controls the transcription of key genes involved in sexual development and reproduction, and binds the AMHRE 1. A mutation that abolished binding of SF-1 to the region demonstrated that the SF-1 binding site was essential for sex and cell specific AMH promoter activity (Giuli et al., 1997). A second SF-1 binding site exists in the distal part of the AMH promoter in humans (Watanabe et al., 2000). It was thought that SF-1 regulates AMH in vivo and participates directly in the process of mammalian sex determination (Shen et al., 1994).

Other factors also play a role in the expression of AMH. Pelletier et al. (1991) suggested that WT-1 (Wilms tumor protein), which plays an essential role in the normal development of the urogenital system, might be involved in the modulation of AMH mRNA expression. WT-1 mutations are often associated with persistent Mullerian duct structures (Little et al., 1997). In co-transfection studies, WT-1 associates with AMH activation and this activation of the AMH promoter by WT-1 only occurs in the presence of AMHRE-1. Further, the synergistic association is antagonized by co-expression of Dax 1 (Nachtigal et al., 1998).

The AMH promoter also contains a canonical SOX binding site (Sry related HMG box) that can bind the transcription factor SOX 9. SOX 9 can associate with SF-1 in activating the AMH promoter (Santa Barbara et al., 1998). The AMH promoter is also a target for the zinc finger transcription factors GATA 1 and GATA 4 (Vigier et al., 1998: Beau et al., 2000). 
Multiple GATA binding sites were found in the AMH promoter and both GATA 1 and GATA 4 were able to bind to these sites (Watanabe et al., 2000). GATA 4 indirectly enhances AMH gene expression through association with SF-1 (Tremblay et al., 1999).

It has been proposed that gonadotropins regulate AMH expression. However conflicting results exist. Pellat et al. (2007) reported that in vitro neither FSH nor LH have an effect on production of AMH from human granulosa cells of normal ovaries. In contrast, in polycystic ovaries LH enhances and FSH inhibits AMH production. Further, human chorionic gonadotropin (HCG) enhances AMH expression in human granulosa cells (Voutilainen et al., 1987), and primates (marmoset) treated with GnRH antagonist showed a decrease in AMH expression in preantral follicles (Thomas et al., 2007).

Treatment of prepubertal rats with gonadotropin releasing hormone $(\mathrm{GnRH})$ antagonist and estradiol benzoate resulted in follicle growth and inhibition of AMH and AMHRII mRNA expression in some but not all preantral and small antral follicles (Baarends et al., 1995). This study provided evidence that FSH and estrogens may play a role in the down regulation of AMH and AMHRII mRNA when small antral follicles differentiate into large antral follicles (Baarends et al., 1995). However, the period just after superstimulatory treatments with FSH, plasma concentrations of AMH appears to be greater than normal physiological concentrations (Rico et al., 2009). The authors suggested that this increase in AMH following FSH treatment may be due to the growth of small follicles that were not detected by ultrasonography (Rico et al., 2009; 2012). In contrast, goats administered exogenous FSH showed a transient decrease in AMH due to the depletion of small antral follciles and development of preovulatory follicles (Monnaiux et al., 2011). FSH also decreased AMH expression in granulosa cells from rats (Baarends et al., 1995) and cattle (Rico et al., 2011), and in polycystic ovaries from humans (Pellatt et al., 2007). 


\section{Variation in systemic concentration of AMH}

\section{Systemic Concentration of AMH}

The concentration of AMH was reported to be between 60 to $570 \mathrm{pg} / \mathrm{ml}$ in Bos Taurus and 60 to $780 \mathrm{pg} / \mathrm{ml}$ in Bos indicus heifers (Batista et al., 2014; Guerreiro et al., 2014; Ribereiro et al., 2014). In sheep and goats the range of AMH reported was 0 to $590 \mathrm{pg} / \mathrm{ml}$ (Lahoz et al., 2012;2014) and 80 to $500 \mathrm{pg} / \mathrm{ml}$ (Monnaiux et al., 2012), respectively. In water buffaloes, the concentration of AMH reported was 110 to $320 \mathrm{pg} / \mathrm{ml}$ (Baldrighi et al., 2014). Stojsin-Carter et al. (2016) evaluated the plasma concentration of AMH in Bos taurus indicus (Zebu) and Bos taurus taurus (European type cattle) and reported that the Zebu cattle had a higher concentration of AMH (770 vs $330 \mathrm{pg} / \mathrm{ml}$, respectively).

Variation in concentration of AMH within and among breeds

In ovaries of domestic animals, the populations of small antral growing follicles show little change with time (Scaramuzzi et al., 2011.). Since small antral growing follicles produce the highest concentrations of $\mathrm{AMH}$, plasma $\mathrm{AMH}$ would be expected not to vary significantly over time for each animal. The concentration of AMH in Holstein dairy cows aged 4 to 9 years did not change over a three-month period (Rico et al., 2009), and measurements taken before OPU protocols over one year was significantly correlated with each other $(\mathrm{r}=0.88$, Rico et al., 2012) . In nulliparous Saanen goats, plasma concentrations of AMH showed little change due to season (Monnaiux et al., 2011). Concentration of AMH was not affected by stage of the estrous cycle or month of gestation (Almeida et al., 2011) in Holstein and Jersey dairy heifers and the concentration of AMH at estrus did not differ between the natural or synchronized estrous cycles 
(Pfeiffer et al., 2014). These studies provide evidence that the concentration of AMH may be a characteristic of individual animals and is relatively stable. Although concentrations may remain very constant within a female, female to female variations exist. In both Holstein and Jersey heifers, the concentration varied from 2 to $218 \mathrm{pg} / \mathrm{ml}$ (Pfeiffer et al., 2014). In other studies with Holstein heifers were assessed the concentration of AMH varied from 25 to $228 \mathrm{pg} / \mathrm{ml}$ (Ireland et al., 2009) and 6 to $433 \mathrm{pg} / \mathrm{ml}$ (Ireland et al. 2011).

$\mathrm{AMH}$ also seems to vary among livestock species. The concentration of AMH was higher in Bos indicus than Bos taurus heifers (Baldrighi et al., 2014; Guerreiro et al., 2014; Batista et al., 2014; Stojsin-Carter et al., 2016).

Variation in concentration of AMH during the Estrous Cycle

Several studies suggest indicate that the concentration of AMH measured through a full menstrual cycle does not show consistent fluctuations (La Marca et al., 2004; Hehenkamp et al., 2006; Tsepelidis et al., 2007). In contrast, Wyunder et al. (2008) reported that the concentration of AMH declined from between 3190 to $3280 \mathrm{pg} / \mathrm{ml}$ in the preovulatory period to 2700 to 2630 $\mathrm{pg} / \mathrm{ml}$ in the early luteal phase. In addition, the concentration of AMH ranged from $1400 \mathrm{pg} / \mathrm{ml}$ in the early follicular phase, peaked mid cycle at $1700 \pm 1100 \mathrm{pg} / \mathrm{ml}$ and declined to $1400 \mathrm{pg} / \mathrm{ml}$ in the mid luteal phase of the normal menstrual cycle (Cook et al., 2000).

Concentrations of $\mathrm{AMH}$ were similar at estrus and during the subsequent period in Holstein cows classified either as high AFC or low AFC (Rico et al., 2011). There was no change in the concentration of AMH from days 6 to 9 prior to ovulation in Angus, Charolais and Hereford heifers (Ireland et al., 2008), and a strong positive correlation existed in AMH 
measured in blood samples taken at random time points and those taken at proestrus and diestrus (Souza et al., 2014). Further, a high correlation $\left(r^{2}=0.97\right)$ was reported between any single AMH measurement and the overall mean of four to eight daily AMH measurements in the same individual beef heifer (Ireland et al., 2011). These studies provide evidence that the concentration of $\mathrm{AMH}$ in a female may be constant during estrous cycles. In contrast, the concentration of AMH decreased after estrus with minimal concentrations between day 4 and day 8 of the estrus cycle followed by a slow increase until the next estrus (Rico et al., 2011). The author further suggested that this increase after estrus was as a result of the inhibition by FSH and is not associated with the decrease in the population of small antral follicles. Furthermore Plasma $\mathrm{AMH}$ concentration appears to be greater than normal physiological levels during the period just after superstimulatory treatments (Rico et al., 2009; 2012)

\section{Effects of AMH on follicle development in the ovary}

\section{Early Follicular Development and Cyclic Recruitment of Follicles and Ovulation}

The ovaries at birth contain a large reserve of non-growing primordial follicles that consist of an immature quiescent egg or oocyte, surrounded by a single layer of flattened pregranulosa cells (Aerts et al., 2010). The number of primordial follicles has been reported to be 12,000 to 19,000 in buffalo heifers (Samad et al., 1979). In contrast, Erickson et al. (1966) reported that in cattle the average number is 150,000 . 
Primordial follicle activation refers to the process by which primordial follicles gradually exit the nongrowing follicle pool and enter the intermediate or primary follicle stage (Picton et al., 20010. This activation may be dependent on signals originating in the ovary, pituitary and metabolism related hormones that are required for folliculogenesis (Picton et al., 2008). In the ovary the cross talk between oocytes and granulosa and theca cells occur at an early stage of follicular development (Matuk et al., 2002). The activation of primordial follicles is associated with oocyte growth and differentiation of the pre-granulosa cells (Da Silva-Buttkus et al., 2008). The proliferation of these granulosa cells allows multiple layers of cells to originate resulting in the development of follicles to pre antral and antral follicles (Lintern-Moore et al., 1979; Picton et al., 2001).

Follicular growth and development in cattle is characterized by two (Ginther et al., 1989) or three (Burke et al., 2000) waves per estrous cycle. Each wave involves the recruitment of a cohort of follicles, selection of a group of follicles and dominance of a single follicle (Ginther et al., 1989). The necessary features of follicle recruitment, selection, dominance and atresia during a follicular wave in water buffaloes are similar to those reported in cattle (Sirois et al., 1988; Ginther et al., 1989). In an estrous cycle, the number of follicular waves in buffaloes may vary from 1 to 3 with 2 waves being the most common (Baruselli et al., 1997; Neglia et al., 2007). However, in cattle, four follicular waves have been reported (Rhodes et al., 1995; De Renesis et al., 1999).

The dynamics of antral follicles involve three main processes, recruitment (emergence), selection and dominance. Recruitment is the phase of follicular development in which a cohort of small antral follicles that escape apoptosis, due to increasing levels of FSH, begin to grow (Mc Gee et al., 2000; Draincourt et al., 2001). Regression of the dominant follicle during a growth 
wave or ovulation at the end of an estrous cycle causes a brief elevation of circulating concentrations of FSH. Loss of the dominant follicle is accompanied by decreased levels of estradiol and inhibin synthesized by the follicle (Aerts et al., 2010). The low levels of estradiol and inhibin reduce the negative feedback to the hypothalamic- pituitary axis resulting in increased secretion of FSH (le Nestour et al., 1993; Chun et al., 1996; McGee et al., 2000). However, circulating concentrations of FSH need to surpass a certain level known as the FSH threshold level for the follicles to grow (Brown et al., 1978).

As the selected follicle proceeds towards dominance, FSH stimulates the secretion of increasing amounts of estradiol and inhibin produced by the growing follicles (Glister et al., 2001). At the beginning of deviation, which is the differentiation that occurs between the future dominant follicle and subordinate follicles (Beg et al., 2006), increasing amounts of estradiol and inhibin suppress FSH levels during the entire FSH decline (Ginther et al., 2003). The FSH decline is necessary for the establishment of deviation. Increasing endogenous FSH or administering FSH early in a wave induces several follicles to become dominant. In polytocous species such as dogs, cats and pigs, a cohort of follicles becomes dominant (Evans et al., 2003; Hunter et al., 2004; Senger et al., 2005). However, in monotocous species such as cattle, horses and humans, a single follicle develops into a dominant follicle while the remaining follicle regresses (Ginther, 2000; Senger et al., 2005). With decreasing serum concentrations of FSH, subordinate follicles begin to undergo changes such as reduced production of estradiol, inhibin and increased production of insulin like growth factor (IGF-1) binding proteins (IGFBPs) (Sunderland et al., 1996; Mihm et al., 1997) resulting in granulosa cell apoptosis. The estradiol that is secreted by the future dominant follicle also increases the expression of genes for 
aromatase, 3 beta-hydroxysteriod dehydrogenase and receptors for FSH and LH in granuolsa cells (Bao et al., 1998).

FSH stimulates the proliferation and aromatase activity in granulosa cells of large antral follicles. This initiates the conversion of androstenedione (from theca cells) to estradiol (Baerwald et al., 2012). Both luteinizing hormone (LH) stimulation in the theca cells and FSH stimulation in the GCs are required for estradiol production, stimulating the mitotic activity of GCs and enhancing the proliferation effect of FSH in the follicle. The relationship between the growing follicles and FSH is described as a two-way functional coupling mechanism, where the growing follicles inhibit FSH secretion through production of estradiol and inhibin. However, follicles are still dependent on FSH to grow (Gougeon, 1996; Ginther et al., 2000; 2001). Following the decline in FSH the dominant follicle changes to a single follicle FSH coupling, which provides restricted levels of FSH that enable only the future dominant follicle to survive (McNatty et al., 1983; Fauser et al., 1997; Ginther et al., 2000; 2001). However even during the dominance phase, basal FSH levels remain important, and suppression of basal concentrations will arrest the growth of the dominant follicle in cattle (Truzillo et al., 1993).

The dominant follicle is able to continue to grow in the existing endocrine environment by efficiently using FSH and FSH dependent growth factors. FSH can also enhance availability of growth factors. For example FSH induces pregnancy associated plasma protein - A (PAPPA), a protease that degrades IGFBP-4 and IGFBP-5 resulting in increased free IGF concentrations. Increased IGF-1 acts in synergy with FSH to increase estradiol (Fortune et al., 2004). 
In cattle, $\mathrm{LH}$ receptors form on the granulosa cells of the dominant follicle following the secretion of estradiol (Bodensteiner et al., 1996; Ginther et al., 2001). The dominant follicle becomes less dependent on FSH and more dependent (a transition in gonadotropin dependency) on LH (Sullivan et al., 1999; Filicori et al., 2002; Mihm et al., 2006). To support this, Crowe et al. (2001) evaluated the roles of FSH and LH in follicular growth in GnRH immunized anestrous heifers randomly assigned to three groups, group 1 received $1.5 \mathrm{mg}$ porcine FSH (pFSH) four times a day for two days, group 2 received 150 ug porcine $\mathrm{LH}(\mathrm{pLH}) 6$ times a day for six days and group 3 received both as described for groups 1 and 2. The authors reported that heifers treated with pLH only failed to stimulate follicle growth greater that $5 \mathrm{~mm}$ and heifers treated with pFSH stimulated growth of medium follicles that were estradiol inactive and failed to increase serum estradiol levels. Heifers treated with both $\mathrm{pFSH}$ and $\mathrm{pLH}$ stimulated growth of estradiol active large follicles which resulted in a 10 to 14-fold increase in concentration of serum estradiol.

Pre-ovulatory LH pulses are also important in follicle maturation and ovulation. Filion et al. (2001) reported that in response to the LH surge in humans, the E series prostaglandins (mainly $\mathrm{PGE}_{2}$ ) are produced by the follicle which is essential for the successful rupture of the follicle and release of the oocyte into the periovarian space. In addition, LH stimulates and prepares the granulosa cells for luteinization (Smith et al., 2014; Stouffer et al., 2007). Hydration of these cumulus cells which produce hyaluronic acid, enables cumulus expansion through the enlargement of the space between granulosa cells (Eppig, 2001). Episodic LH pulses are necessary for the formation of CL (corpus luteum) in cattle but not required for the maintenance of luteal function (Aerts et al., 2010). In addition, using a GnRH antagonist on days 2-7 and 1217 of the cycle to block LH pulses resulted in diminished luteal function (Peters et al., 1994). 
Treatment with GnRH on days 12-17 did not influence CL function. Progesterone produced by the CL resulted in a lower pulse frequency in the mid-luteal phase and atresia in the $\mathrm{LH}$ dependent dominant follicle (DF). Luteolysis during the dominant phase will result in ovulation of the growing DF. If the CL remains active the second DF will regress due to progesterone secretion and LH suppression. The DF would only fully mature and ovulate if during the follicular phase.

\section{AMH and Folliculogenesis}

$\mathrm{AMH}$ has an important role in the regulation of mammalian follicular development (Durlinger et al., 1999; Knight et al., 2003; Seifer et al., 2007). This idea was based on the work of Baarends et al. (1995) who reported that there are specific patterns of expression of AMH and AMHR11 in the postnatal ovary and the changes of expression during the estrous cycle in rats.

Durlinger et al. (1999) studied the follicle population in AMH deficient female mice and reported that in the absence of $\mathrm{AMH}$, primordial follicles became depleted. Durlinger et al. (2002b) examined neonatal mouse ovaries cultured in vitro for 2 or 4 days in the absence and presence of $\mathrm{AMH}$ and reported that 2 day old ovaries contained primarily primordial follicles. AMH caused a 40 to $50 \%$ reduction in the number of growing follicles after 2 and 4 days of culture. Expression of AMHR11 and oocyte markers GDF9 (Growth Differentiation Factor 9) and ZP3 (Zona Pellucida glycoprotein 3) were not influenced by AMH. The same authors suggested that the absence of AMH results in increased recruitment of primordial follicles. At 13 months old, the primordial follicles in AMH deficient mice were completely depleted and only a small number of growing follicles existed. In addition, 56\% of the AMH deficient mice at 16 to 
17 months had stopped ovulating. AMH prevented the activation of primordial follicles (Fortune et al., 2010). These studies provide evidence that AMH prevents initial recruitment and activation of primordial follicles into the growing pool. In addition, AMH also prevents the premature depletion of the follicular population in the ovary.

\section{AMH and FSH action}

AMH may inhibit FSH induced follicular growth (Durlinger et al., 1999). In mice Durlinger et al. (2001) evaluated the effect of AMH on FSH stimulated follicle growth on small (diameter 135-165 $\mu \mathrm{m}$ ) and large (diameter 165-210 $\mu \mathrm{m}$ ) preantral follicles. The authors reported that addition of exogenous AMH caused inhibition of FSH stimulated preantral follicle growth. FSH stimulation of follicles was more pronounced in the AMH deficient mice than in their wild type counter parts (Durlinger et al., 2001). These two pieces of evidence provides support that in the absence of $\mathrm{AMH}$, females are more responsive to FSH. In contrast, AMH had a synergistic effect on FSH-stimulated growth of follicles (McGee et al., 2001).

In an in vitro primary cell culture study, Grossman et al. (2008) investigated the effects of AMH on cytochrome P450 aromatase (CYP19) gene expression in cultured human granulosa lutein cells (GLC) and reported that AMH inhibits FSH induced increases in CYP19 enzyme activity and gene expression in GLC. Chang et al. (2013) extended Grossman's work and reported that AMH significantly reduced FSH stimulated aromatase expression, estradiol accumulation and inhibited FSH induced adenylyl cyclase activation through AMHR2. However, FSH receptor messenger RNA and protein levels were not altered by AMH (Chang et al., 2013). AMH decreased gonadotropin stimulated aromatase expression through the repression of the 
CYP19 gene in rat luteinized GCs (Pellatt et al., 2011). AMH does not affect the basal expression of aromatase but specifically reduces the FSH stimulating effect (Prapa et al., 2015).

The inhibitory effects of AMH on FSH sensitivity of follicles may play an important role in the selection process. A group of follicles is selected from the group of AMH producing growing follicles to continue growth to the pre-ovulatory phase. McGee et al. (2000) suggested that in rodents, selection takes place at estrous because of the secondary FSH peak (van Cappellen et al., 1993). However, it was thought that depending on the developmental stage each follicle would require a certain concentration of FSH to continue growth. That is, each follicle displays its own FSH threshold concentration and this threshold had to be exceeded to ensure growth to the preovulatory stage (Brown, 1978; Schipper et al., 1998). Since AMH affects FSH sensitivity of the follicles, it may play a role in the determining which follicles undergo selection and which are removed through atresia. In the rat ovary, such a role is supported by the differential expression of AMH in non-atretic large preantral and small antral follicles (Baarends et al., 1995). Visser et al. (2005) suggested that some follicles showed lower AMH expression than others and these follicles may be more sensitive to FSH and more prone to be selected by the secondary estrous FSH peak.

\section{AMH and antral follicular population (AFP)}

In humans, AFP is positively correlated with concentration of AMH. De Vet et al. (2002) reported that concentration of AMH and AFC were highly correlated $(r=0.66 / 0.71)$. In addition, a strong correlation $(\mathrm{r}=0.74)$ exists between the concentration of AMH and AFP (Fanchin et al., 2003). Further, circulating AMH concentrations are positively associated with the total number 
of healthy follicles in the ovaries of mice ( $r=0.83$; Kevenaar et al., 2006). This relationship is also evident in livestock species. In cattle, the number of ovarian follicles is variable across females and highly repeatable within individuals (Ireland et al. 2007; 2008). In addition, a positive relationship exists between AFC and concentration of AMH in Murrah water buffalo ( $\mathrm{r}$ $=0.62)$, Holstein $(r=0.66)$ and Gyr $(r=0.88)$ heifers (Baldrighi et al., 2013). The number of follicles greater than $2 \mathrm{~mm}$ was positively correlated with AMH in Holstein and Nelore heifers (Batista et al., 2014; 2016). Rico et al. (2009) found that AMH concentration was highly correlated with the number of 3 to $7 \mathrm{~mm}$ antral follicles $(r=0.79)$ in Holstein cows. Using AMH as a predictor of AFC might be a choice in contrast to the use of ultrasonography as AMH levels vary minimally during the estrous cycle.

Both the AFP and concentration of AMH vary across genetic groups. Bos indicus heifers showed greater AFP than their Bos taurus counterparts (28.4 vs. 13.4; Batista et al., 2014). AMH concentrations were also higher in Bos indicus than Bos taurus counterparts (780 vs. $60 \mathrm{pg} / \mathrm{ml}$ ) (Batista et al., 2014).

Different threshold values have been used to classify animals as having high or low concentrations of $\mathrm{AMH}$. AMH concentrations that were considered low and high respectively were 60 and $570 \mathrm{pg} / \mathrm{ml}$ (Batista et al., 2014) and 200 and $400 \mathrm{pg} / \mathrm{ml}$ (Guerreiro et al., 2014) in Bos taurus; 780 and $1200 \mathrm{pg} / \mathrm{ml}$ (Batista et al., 2014) and 200 and 500 pg/ml (Guerreiro et al., 2014) in Bos indicus; and 110 and $320 \mathrm{pg} / \mathrm{ml}$ in Bubalis bubalus (Baldrighi et al., 2014). AFP that were considered low and high were 13 and 34 (Batista et al., 2014) and 24 and 69 (Baldrighi et al., 2014) in Bos taurus; 28 and 48 (Batista et al., 2014) and 44 and 98 (Baldrighi et al., 2014) in Bos indicus; and 22 and 34 in Bubalus bubalis (Baldrighi et al., 2014). These observations 
reinforce the importance of separately considering the genetic backgrounds of animals when using the concentration of $\mathrm{AMH}$ as a predictor of $\mathrm{AFC}$ or other reproductive outcomes.

\section{AMH and superovulation}

$\mathrm{AMH}$ is classified as a good predictor of ovarian response to gonadotropin stimulation treatments in both humans and in livestock species. In humans, concentrations of AMH is associated with ovarian response in IVF patients (number of oocytes retrieved: $r=0.52$ and 0.57 ; Seifer et al., 2002; Van Rooij et al., 2002, respectively). Poor ovarian response, which was assessed as having fewer than 4 oocytes or cycle cancellation, was associated with low AMH in humans (Van Rooij et al., 2002). Circulating concentration of AMH has the ability to predict poor $(910 \mathrm{pg} / \mathrm{ml})$, normal $(3040 \mathrm{pg} / \mathrm{ml})$ and high $(5560 \mathrm{pg} / \mathrm{ml})$ responders to stimulation with exogenous gonadotropins (Nardo et al., 2009). Concentration of AMH was positively correlated with the number of oocytes $(r=0.259)$ and the number of embryos $(r=0.206$; Tsakos et al., $2014)$ and was significantly different between poor (2070 pg/ml), normal (2530 pg/ml) and high (3450 pg/ml) responders to ovarian stimulation (Tsakos et al., 2014). There is a strong association between day 3 serum concentration of AMH and number of metaphase II oocytes ( $r=$ $0.38)$ and total number of embryos $(r=0.34)$ following IVF in women younger than 42 years (Hazout et al., 2004) and higher concentrations of AMH were associated with greater number of mature oocytes, a greater number of embryos and a higher clinical pregnancy rate (Hazout et al., 2004). Both AFC and concentration of AMH had significant correlations with number of oocytes retrieved and the number of oocytes fertilized (Majumder et al., 2010). Kotanidis et al. (2013) 
reported that a strong correlation exists between the concentration of $\mathrm{AMH}$ and the number of oocytes retrieved $(r=0.86)$.

Superovulation is an important reproductive strategy for the increase, preservation and utilization of animal genetics. In cattle, the number of transferable ova/embryos produced following superovulation varies between 4 to 12 (Bo et al., 2014; Gabriel et al., 2014; SilvaSantos et al., 2014; Hasler et al., 2014; Souza et al., 2014). In comparison to cattle, the average number of recoverable embryos derived from water buffaloes using similar superovulatory protocols is less than 2 (Madan et al., 1996; Carvalho et al., 2002; Neglia et al., 2003; Drost et al., 2007; Li et al., 2011). In addition, the mean embryo recovery rate of 1-2 has been reported in superovlated Mediterranean (Neglia et al., 2010) and Swamp (Songasen et al., 1999; Techakumpu et al., 2001) buffaloes.

The yield of transferable embryos is influenced by several factors such as age, parity and nutrition (Hasler, 2014). In addition, the superovulation protocol and the follicle stimulating hormone $(\mathrm{FSH})$ preparations used in these protocols affect the superovulatory response (Lerner et al., 1986; Madan et al., 1996; Kafi et al., 1997; Hasler, 2014). High luteinizing hormone (LH) content (low FSH/LH ratio) negatively affects the superovulatory response, fertilization rate and embryo recovery (Murphy et al., 1984; Kelly et al., 1995). In cattle, donors treated with FSH preparations with a low LH content produced more viable embryos, total number of ova recovered and a higher fertilization rate (Chupin et al., 1984; Mapletoft et al., 1988; Lopes de Costa et al., 2001; Quaresma et al., 2003).

Excess LH can cause premature luteinization or ovulation of the FSH-stimulated follicles by altering their endocrine milieu in cows (Callesen et al., 1986; 1987) and sheep (D’ Aessandro et al., 2016). In contrast to the negative effects of excess LH, Garza et al. (1984) suggested that 
in the guinea pig exogenous LH might induce the recruitment of small follicles by prevention of atresia. Breen et al. (2012) suggested in prepubertal gilts, that a greater amount of LH is needed to sustain small follicles and to stimulate their development.

In different livestock species, a strong positive relationship between circulating concentration of AMH and response to superovulation exist. A positive correlation was observed between plasma AMH of donor cows and the average $(r=0.49)$ and maximal number of embryos $(r=0.58)$ collected per cow (Monniaux et al., 2010). The average concentration of AMH was also positively correlated with the average $(r=0.32)$ and maximal $(r=0.38)$ numbers of transferable embryos per donor cow (Monniaux et al., 2010).

In dairy cows positive correlations have been reported between $\mathrm{AMH}$ and the number of large follicles at OPU ( $r=0.65$; Rico et al., 2012); the number of large follicles and oocytes at OPU $(r=0.75$ and $r=0.70$, respectively; Rico et al., 2012); the number of embryos $(r=0.46$, Rico et al., 2012); the number of transferable embryos ( $r=0.28$; Souza et al., 2014) and the number of CL ( $r=0.65$; Souza et al., 2014) were all positively correlated with AMH. In goats the concentration of AMH measured before the superovulatory treatment were highly correlated with the total number of corpora lutea $(r=0.71)$, total number of collected $(r=0.87)$, transferable $(\mathrm{r}=0.83)$ and freezable $(\mathrm{r}=0.78)$ embryos (Monniaux et al., 2011).

Over the last four decades, in vitro embryo production (IVEP) has increased. Rrecent studies have identified $\mathrm{AMH}$ as an endocrine marker to select donors with the greatest potential to serve as donors for in vitro embryo production. In Bos taurus (Holstein) and Bos indicus (Nelore) donors, the concentration of AMH is positively correlated with the number of in vitro embryos produced from Holstein $(r=0.36)$ and Nelore $(r=0.50)$ cattle (Guerreiro et al., 2014). Donors classified as having high concentration of AMH yielded a greater number of embryos 
produced per OPU after superovulation as compared with those classified as having a low concentration of AMH (Holstein: 3 vs. 1.2; Nelore: 7. vs. 2.2; Guerreiro et al., 2014). In Holstein-Friesian heifers the concentration of AMH was positively correlated with the number of follicles aspirated per OPU session $(\mathrm{r}=0.45)$, recovered oocytes per OPU $(\mathrm{r}=0.43)$ and in vitro produced embryos per OPU ( $r=0.28$; Vernunft et al., 2015). Batista et al. (2016) evaluated the association between plasma concentrations of $\mathrm{AMH}$ and in vitro embryo production in Bos indicus (Nelore) and Bos Taurus (Holstein) calves and reported a positive correlation between concentration of AMH and the cumulus-oocyte complexes (COCs) retrieved (Nelore: $\mathrm{r}=0.91$; Holstein: $r=0.82$ ), COCs cultured (Nelore: $r=0.71$; Holstein: $r=0.79$ ) and blastocysts produced (Nelore: $r=0.62$; Holstein: $r=0.58$ ).

\section{AMH and Reproductive Performance}

Recent studies observed a positive association between the concentration of $\mathrm{AMH}$ and fertility in dairy cows and sheep. In cattle, cows that became pregnant from re-insemination using AI tended to have greater concentrations of AMH than those that did not become pregnant (Ribeiro et al., 2014). Also cows that became pregnant during the natural service period and those that retained their pregnancy had greater concentrations of AMH than those that did not become pregnant (Ribeiro et al., 2014). In 11 to 15 month old Holstein heifers, the quartile of heifers with the lowest concentration of AMH (mean: $19 \mathrm{pg} / \mathrm{ml}$ ) had a shorter productive herd life, a reduced survival rate after birth of first calf, the lowest level of milk production at first lactation and the lowest total percentage of cows pregnant across all lactations (71 vs. 85 vs. 89 vs. $79 \%)$ compared to their herd counterparts in quartiles $2(41.8 \mathrm{pg} / \mathrm{ml}), 3(68.9 \mathrm{pg} / \mathrm{ml})$ and 4 
(153.2 pg/ml; Jimenez-Krassel et al., 2014). A positive correlation exists between the concentration of AMH at 3.6 months of age and pregnancy rate of ewes at first $(r=0.34)$, at second $(r=0.33)$ and both service periods $(r=0.36$; Lahoz et al., 2012). Plasma concentration of $\mathrm{AMH}$ in prepubertal females was higher in ewes that became pregnant at the first mating than those which failed to conceive at first but became pregnant at the second mating or in nonpregnant ewes after two service periods (Lahoz et al., 2012). Fertility at second mating or after both consecutive service periods was also higher in ewes with the concentration of AMH equal or higher than $97 \mathrm{pg} / \mathrm{ml}$ before puberty (93 vs. $72 \%$ and 97 vs. $76 \%$, respectively). The authors noted that the fertility at first mating of ewes with the concentration of AMH being equal to or greater than $97 \mathrm{pg} / \mathrm{ml}$ before puberty was $34.8 \%$ higher than that of their counterparts with low concentration of AMH.

\section{AMH, Ovarian Reserve and Aging}

$\mathrm{AMH}$ in females is primarily produced by the granulosal cells of the ovarian follicle and concentration of AMH is positively correlated to AFC in mice (Durlinger et al., 2002b), women (Fanchin et al., 2003), cattle (Ireland et al., 2008; Rico et al., 2009; Souza et al., 2014; Batista et al., 2014; Batista et al., 2016) and water buffaloes (Baldrighi et al., 2014). Both AMH and AFC decreases with age in humans (Fanchin et al., 2003; Piltonen et al., 2005; Visser et al., 2013) and cattle (Cushman et al., 2009; 2010; Monnaiux et al., 2013). In anovulatory women, particularly those exhibiting polycystic ovaries (PCO), a negative correlation between age and concentration of AMH exist (Mulders et al., 2004). In aging mice concentration of AMH decreases and the 
number of ovarian follicles directly correlates with this decline (Kevenaar et al., 2006). These studies provide evidence that the concentration of AMH decreases over time in females.

Many studies in the literature reported that there is a strong positive correlation between the concentration of $\mathrm{AMH}$ and $\mathrm{AFC}$ which aids in predicting the status of the ovarian reserve. In cattle, reproductive longevity is an important factor affecting profitability (Renquist et al., 2006). Decreased pregnancy rates with increasing parity have been reported in dairy cows (Martinez et al., 2004). In beef cows when AFC was regressed on age, there was a quadratic effect of age such that AFC increased until 5 years of age and then decreased thereafter $\left(r^{2}=0.22\right.$; Cushman et al., 2009). However, AMH was not determined in this study. In a second study, Cushman et al. (2010) suggested that the concentration of AMH could be used to identify heifers of high potential at a very young age. The author reported that in 2-year-old beef heifers, AMH gene expression within the ovarian cortex increased as AFC increased. In addition, the number of follicles increased as cows aged from 1.5 to 6 years and began to decrease thereafter (Cushman et al., 2010).

Some effects of age on AFC and fertility have also been reported. Lerner et al. (1986) reported the number of embryos, rates of fertilization, quality of embryos and numbers of transferable embryos decreased with increasing age of the donor. Requist et al. (2006) reported that pregnancy rate changes quadratically with age. The number of 4 to $5 \mathrm{~mm}$ follicles recruited into a follicular wave was lower in older cows (Malhi et al., 2005). In a second study Malhi et al. (2007) compared old (13-16 years of age) and young cows (3 to 6 years of age) and reported fewer embryos and a higher proportion of unfertilized oocytes/uncleaved zygotes were recovered from old cows. In addition, after superstimulation older cows had fewer follicles greater than 6 mm than their daughters (3-6 years of age; Malhi et al., 2008). 


\section{Conclusion}

Several studies on the function of $\mathrm{AMH}$ in the postnatal ovary in humans and different livestock species indicates that AMH has two main functions during follicular development: (1) AMH plays an inhibiting role during the initial recruitment when primordial follicles are initiated

to grow and (2) AMH can influence the growth of preantral and small antral follicles by decreasing the FSH responsiveness. This effect may be important during cyclic recruitment when individual large preantral and small antral follicles are recruited to grow on to the preovulatory stage.

The measurement of circulating concentrations of AMH in livestock may be a useful tool to identify animals most likely to have the maximum response to superovulatory treatments. In addition, the concentration of AMH may be used to select animals with improved fertility. However, research on these potential effects of $\mathrm{AMH}$ in species other than humans and cattle is limited but will be useful in identifying animals with greater fertility and productive life. 


\title{
CHAPTER 3
}

\section{THE RELATIONSHIP BETWEEN THE CONCENTRATION OF AMH AND FERTILITY IN REPLACEMENT FEMALES}

\begin{abstract}
The effect of breed and age on the concentration of anti-mullerian hormone (AMH) and the relationship between AMH and fertility in replacement ewes were evaluated. In Experiment 1, a single blood sample was used to compare concentration of AMH in Dorset/Texel (DT; n= 238; age $8.7 \pm 0.1$ months $)$, Suffolk $(n=44)$ and Katahdin $(n=77$; age $6.9 \pm 0.04$ months $)$ replacement females and to determine changes in systemic AMH with age in DT and Katahdin females. In Experiment 2, Katahdin and DT females were placed into LOW, MEDIUM and HIGH groups based on their systemic AMH determined from a blood sample collected 2 months prior to breeding. Females were treated with CIDR inserts (0.3g progesterone) for 5 days and were exposed to rams at insert removal for 30-35 days. Ewes were observed for estrus after 4 days of ram exposure, and pregnancy diagnosis was conducted via transrectal ultrasonography at the time of ram removal and again 20-25 days. In Experiment 1, Katahdin females had a higher AMH than DT and Suffolk females (P<0.001: $566 \pm 37$ vs. $337 \pm 14$ vs. $237 \pm 22$ pg/ml, respectively). AMH decreased linearly with age in DT females $(\mathrm{P}=0.03)$. In Experiment 2, Females with high AMH conceived and lambed to the first service in Katahdin but not the DT breed (Breed x AMH; P < 0. 05). Replacement females that conceived (Breed X Conception; P < 0.001 ) and lambed to the first service (Breed $\mathrm{X}$ lambing to $1^{\text {st }}$ service; $\mathrm{P}<0.001$ ) had a higher AMH in Katahdin but not DT breed. In conclusion, AMH varies among different breeds of sheep and a single measure may be useful to select females with high reproductive performance in some breeds.
\end{abstract}




\section{Introduction}

The profitability of sheep operations is highly correlated with reproductive performance of the flock. Replacement females can make up $25 \%$ of the breeding flock and their reproductive performance is generally lower than that of their flock mates (Quirke et al., 1977; Edwards et al., 2016). Additionally, replacement ewes that are successfully bred within their first year of age are more profitable and show greater lifetime reproductive performance than females bred to lamb at two years for the first time (Young et al., 2011; Kenyon et al., 2011; Kenyon et al., 2014).

Approaches to increase fertility in replacement females have been the subject of significant research efforts over the last five decades (Nieto et al., 2013; Kenyon et al., 2014; Knights et al., 2015). Recently, it was reported that the number of growing antral follicles in young adult cattle may be related to their fertility (Ireland et al., 2008; 2011) and low numbers of antral growing follicles have been related to suboptimal fertility in beef cattle (Cushman et al., 2009; 2010). Anti-Müllerian hormone (AMH) is a member of the transforming growth factor- $\beta$ (TGF- $\beta$ ) family (Cate et al., 1986; Knight et al., 2006) and can be used as a marker of the ovarian follicular reserve in humans (Visser et al., 2005), mice (Kevenaar et al., 2006), cattle (Ireland et al., 2008; Monniaux et al., 2010; Rico et al., 2009; Batista et al., 2014) and bitches (Hollinshead et al., 2016). In cattle, the concentration of AMH is positively and highly correlated with AFC (Ireland et al., 2008; 2011).

In dairy cattle, concentration of $\mathrm{AMH}$ showed a quadratic relationship with lactation number and females with low concentration of AMH had a lower pregnancy rate following first service, and a greater incidence of pregnancy loss between day 30 and 65 of gestation (Ribeiro et al., 2014). In addition, it was suggested that the concentration of AMH may be used as a diagnostic 
tool in young heifers to predict herd longevity (Jimenez-Krassel et al., 2015). Lahoz et al. (2012) reported that concentration of AMH determined at an early age in Rasa Aragonesa sheep, can be used to reliably predict fertility at first mating and suggested the cut off value of $97 \mathrm{pg} / \mathrm{ml}$ to distinguish between females with low and high fertility.

Concentrations of AMH vary among breeds of cattle (Baldrighi et al., 2014; Batista et al., 2014; Guerreiro et al., 2014; Stojsin - Carter et al., 2016) and with age (Cushman et al., 2010; Lahoz et al., 2014). Therefore, the concentration of AMH and the relationship between concentration of AMH and fertility in replacement females might not be consistent across breeds.

Therefore, the objectives of this study were to evaluate the concentration of AMH in replacement females of different breeds and ages and to determine if the relationship between the concentration of $\mathrm{AMH}$ and fertility in replacement females varies with breed.

\section{Materials and Method}

\section{Farm and Animals}

This study was conducted during the fall of 2013, 2014 and 2015 on three farms located in West Virginia and southwestern Pennsylvania. The animals used in this study consisted of Dorset $x$ Texel $(8.7 \pm 0.1$ months [range $4-10.4$ months]; $38.9 \pm 0.58 \mathrm{~kg}$ [range 23.1- $70.3 \mathrm{~kg}$ ]), Katahdin $(6.9 \pm 0.04$ months [range $3.6-5.6$ months]; $23.6 \pm 0.57 \mathrm{~kg}$ [range $13.1-35.8 \mathrm{~kg}$ ] $)$, and Suffolk $(40.5 \pm 0.75 \mathrm{~kg}$ [range $28.2-53.1 \mathrm{~kg}$ ]) replacement females. Two months prior to beginning of the breeding season, replacement females were provided with a grain supplement 
(15\% crude protein, $65 \%$ total digestible nutrients concentrate) ranging in amounts of 0.23 to $0.68 \mathrm{~kg}$ per head per day. All animals were managed on mixed grass legume pastures and were allowed ad libitum access to water and shade.

\section{Treatments}

The procedures used in these studies were approved by the West Virginia University Animal Care and Use Committee (IACUC \# 13-1201).

\section{Experiment 1}

To determine the effect of breed of sheep on the concentration of AMH, a single blood sample was collected from Dorset/Texel $(n=238)$, Suffolk $(n=44)$ and Katahdin $(n=77)$ replacement females (Table 3.1) and assayed for AMH. To determine the relationship between age and concentration of AMH, blood samples were collected from Dorset/Texel and Katahdin replacement females ranging in age from 6 to 12 and 6 to 8 months, respectively.

\section{Experiment 2}

To determine the relationship between the concentration of $\mathrm{AMH}$ and fertility, the concentration of AMH was determined from a single blood sample collected 2 months prior to breeding. Females within the Katahdin breed and Dorset/Texel crosses, were placed into LOW, MEDIUM and HIGH groups respectively, equivalent to $<$ mean $-1 / 2$ standard deviation, $\geq$ mean - 
$1 / 2$ standard deviation $<$ mean $+1 / 2$ standard deviation and $\geq$ mean $+1 / 2$ standard deviation, respectively. Females within the Suffolk breed was not used as the producer experienced significant loss of animals due to sickness. All females were separated from rams prior to the beginning of the experiment and received progesterone via a CIDR device (containing 0.3g of progesterone; InterAg; Hamilton, New Zealand) for 5 days prior to ram introduction. At CIDR removal, replacement females were exposed to a group of sexually mature rams at a ratio not less than one ram per 15 replacement females.

\section{Estrous detection}

Rams fitted with marking harnesses were exposed to replacement females and managed as a single breeding group for approximately 60 days beginning at CIDR removal. To detect estrus at first service period, ewes were observed for the presence of raddle marks between 24 and 96 hours after ram introduction.

Pregnancy diagnosis and lambing data

Pregnancy diagnosis was conducted using transrectal ultrasonography (Aloka 500 Corometrics Medical Systems Wallingford, CT, USA) with a 7.5-mHZ linear trans-rectal probe between 30-35 and 50-55 days after ram introduction to detect pregnancy conceived at first and second service periods, respectively. Lambing records were collected and analyzed. 


\section{Blood Collection and AMH assay}

Blood samples were collected into $10 \mathrm{ml}$ tubes containing EDTA by jugular venipuncture. The samples were immediately placed on ice and later centrifuged at $3000 \mathrm{xg}$ for 15 minutes for separation of plasma. The plasma samples were frozen at $-20{ }^{\circ} \mathrm{C}$ for later analysis. Plasma AMH was determined using an enzyme-linked immunosorbent assay ELISA kit (ANSH labs, Webster, Texas, USA). The sensitivity of the AMH assay was $0.009 \mathrm{ng} / \mathrm{ml}$ and intra-assay $\mathrm{CV}$ was $<5 \%$.

Statistical analysis

To assess the effect of breed on the concentration of $\mathrm{AMH}$, a one way analysis of variance (ANOVA) was conducted using the PROC MIX procedure of SAS (Statistical Analysis System version 9.4 for Windows; SAS Institute, Cary, NC, USA) and means were separated using Tukey's HSD.

A polynomial regression was used to assess the relationship between concentration of $\mathrm{AMH}$ and age in replacement females, the regression between the concentration of AMH and age was determined using the PROC REG procedures of SAS.

A two-way Analysis of Covariance (ANCOVA) was conducted using the PROC MIX procedure of SAS to determine the effect of concentration of AMH (LOW, MEDIUM and HIGH groups), breed and breed $\mathrm{x}$ AMH interaction on reproductive responses controlling for age. Means were separated using Tukey's HSD. Response variables included estrous response, conception rate, pregnancy to first and second services (ewe that lambed that were pregnant to 
first and second services, respectively), prolificacy (number of lambs born per ewe lambing), prolificacy to first service (number of lambs born per ewe lambing to first service only), proportion of ewes (ewes lambing by day 13 of the lambing period) lambing to first service, percentage lambed, lambing rate (lambs born per ewe exposed), ram introduction to lambing, lambing day (day that ewe lambed during the lambing period) and age to first lambing and the effect of conception, pregnancy to first service, percentage lambed and lambing to first service.

ANCOVA was used to investigate whether the concentration of AMH differed from replacement females experiencing a binary reproductive response or not controlling for age. These variables were used in a multivariable model that included the binary reproductive response as an independent variable to explain the variability of concentration of AMH (Ribiero et al., 2014). Reproductive responses investigated were estrous response, conception, pregnancy to first service, lambed and lambing to first service. Results were considered significant at a confidence interval of $\mathrm{P} \leq 0.05$ and a tendency when $0.05<\mathrm{P} \leq 0.1$.

\section{Results}

Relationship between concentration of AMH, breed and age

The mean breeding age of the replacement females were $8.3 \pm 0.01$ months. The mean systemic concentration of AMH for Dorset, Katahdin and Suffolk replacement females were 337

$\pm 14,566 \pm 37$ and $237 \pm 22 \mathrm{pg} / \mathrm{ml}$, respectively. AMH was higher in Katahdin replacement females than Dorset and Suffolk replacement females $(\mathrm{P}<0.001)$. AMH decreased linearly with 
age (Figure 3.1a; $\mathrm{P}=0.03$ ) in Dorset/Texel replacements with age but there was no relationship between age and AMH in Katahdin replacement females (Figure 3.1b).

Relationship between concentration of AMH and reproductive outcomes in Dorset and Katahdin replacement females

There was a significant interaction of breed $\mathrm{x}$ AMH on conception rate (Table 3.2: $\mathrm{P}=$ 0.02 ) and lambing to the first service (Table 3.2; $\mathrm{P}=0.01$ ). More Katahdin replacement females with HIGH AMH conceived $(\mathrm{P}=0.005 ; 90.0 \pm 13.0$ vs. $41.6 \pm 11.9 \%)$ and lambed to the first service period $(\mathrm{P}=0.004 ; 90.6 \pm 15.4$ vs. $31.5 \pm 13.6 \%)$ compared to Katahdin females with LOW AMH. However, conception rate and proportion of females lambing to the first service did not differ among Dorset replacement females with LOW, MEDIUM and HIGH AMH.

Dorset replacement females (Table 3.3) had a higher estrous response $(\mathrm{P}=0.01)$, pregnancy rate to first service $(P=0.002)$, pregnancy rate to second service $(P=0.002)$, prolificacy to first service $(\mathrm{P}=0.03)$, percentage lambed $(\mathrm{P}<0.001)$ and lambing rate $(\mathrm{P}<$ 0.001) than Katahdin replacement females. In addition, Dorset females tended to have a higher conception rate $(\mathrm{P}=0.08)$ and overall prolificacy $(\mathrm{P}=0.09)$ than Katahdin females.

More replacement females with HIGH AMH lambed to the first service period compared to females with LOW and MEDIUM AMH (Table 3.3; $\mathrm{P}=0.04$ ). Replacement females with HIGH AMH tended to have a higher conception rate $(\mathrm{P}=0.07)$ lower number of days from ram introduction to lambing $(\mathrm{P}=0.07)$, lambed earlier within the lambing period $(\mathrm{P}=0.08)$ and lower age to first lambing $(\mathrm{P}=0.08)$. 
AMH Concentrations in plasma according to binary reproductive responses

AMH was higher in replacement females that conceived $(\mathrm{P}=0.01 ; 471 \pm 25$ vs. $360 \pm 37$ $\mathrm{pg} / \mathrm{ml}$ ) compared to females that did not conceive. There was a significant interaction (Table 3.4; $\mathrm{P}=0.0007)$ of breed $\mathrm{x}$ conception. Katahdin replacement females that conceived had a higher $(\mathrm{P}$ $=0.0008)$ concentration of AMH compared to Katahdin females that did not conceive. However, AMH did not differ between Dorset replacement females that conceived and Dorset females that did not conceive.

There was a significant interaction (Table 3.4; $\mathrm{P}=0.009$ ) of breed $\mathrm{x}$ pregnancy to the first service on AMH. Dorset replacement females that were pregnant to the first service had a lower $(\mathrm{P}=0.03)$ AMH compared to Dorset females with HIGH that did not become pregnant to the first service.

AMH was higher in replacement females that lambed to the first service $(P=0.005 ; 507$ \pm 29 vs. $382 \pm 34 \mathrm{pg} / \mathrm{ml}$ ) compared to replacement females that did not lamb to the first service. There was a significant interaction (Table 3.4; $\mathrm{P}=0.0009$ ) of breed $\mathrm{x}$ lambing to first service. Katahdin replacement females that lambed to the first service had a higher $(\mathrm{P}=0.0007)$ concentration of AMH compared to Katahdin females that did not lamb to the first service. However, AMH did not differ between Dorset replacement females that lambed to the first service and Dorset females that did not lamb to the first service. 


\section{Discussion}

There are limited reports on the relationship between circulating concentration of AMH and reproductive variables in replacement females. The present study demonstrated that in replacement females (1) the concentration of AMH differs among breeds of sheep (2) a linear relationship exist between the concentration of $\mathrm{AMH}$ and age in Dorset replacement females (3) in some breeds the concentration of AMH may be a predictor of some reproductive performance variables.

In the present study, concentration of AMH varied among Suffolk, Dorset and Katahdin breeds of sheep. AMH also has been shown to vary with breeds of cattle (Baldrighi et al., 2014; Stojsin-Carter et al., 2016). AMH is produced by pre-antral and early antral follicles and there is a strong correlation between AFP and AMH (Batista el al., 2014; Ribeiro et al., 2014; StojsinCarter et al., 2016). AFP also varies across different breeds in cattle (Gimenes et al., 2009; Sartori et al., 2010) and sheep (Draincourt et al., 1986; Avdi et al., 1997; Webb et al. 1989). Therefore, intra and inter breed variations in concentration of AMH observed in sheep in this study, might be reflective of variations in the AFP. Different threshold values are used for different breeds of cattle to classify animals with low and high AFP populations (Batista et al., 2014; Guerreiro et al., 2014). Therefore it is suggested that because of the wide inter-breed variation observed in this study, a single value to predict reproductive outcome across breeds would not be sufficient.

The concentration of AMH decreased linearly with increasing age in Dorset/Texel replacement females. However the $\mathrm{R}^{2}$ value was 0.0178. A decline in AMH has been reported in the peripubertal period in other species. Monnaiux et al. (2013) reported that the concentration of 
AMH decreased between 6 months and 12 months of age in beef heifers. Lahoz et al. (2014) reported that the concentration of AMH declined between 6 and 19 months of age in Ras Aragonesa ewes, and Fanchin et al. (2003) reported a negative linear relationship between the concentration of AMH and age. In contrast, Hudson et al. (1990) reported that in humans, AMH changed quadratically with age from barely detectable at birth, increases at 11 to 19 years and decreased after 20 years of age. Visser et al. (2013) reported that AMH increased during the postnatal period up to 12 years and decreased at an older age. AMH is correlated with AFC (Ireland et al., 2009; Rico et al., 2009), the decrease in AMH observed in Dorset/Texel females may be due to the decline in AFC with increasing age. However, no relationship between age and $\mathrm{AMH}$ was observed in Katahdin females. Age range of the Katahdin females was small which might have precluded the determination of any relationship between age and concentration of $\mathrm{AMH}$ in this study.

More females with a high concentration of AMH tended to conceive and lamb to the first service. Previous reports observed a positive association between concentration of AMH and fertility. In sheep, Lahoz et al. (2012) reported that ewes with higher prepubertal concentrations of $\mathrm{AMH}$ showed a higher probability of becoming pregnant at first mating than those with a lower concentration of AMH. In addition, ewes which failed to conceive had a lower concentration of AMH (Lahoz et al., 2012). Dairy cows with low AMH concentrations had lower pregnancy following first service and greater incidence of pregnancy loss between day 30 and 65 of gestation (Ribeiro et al., 2014) and a reduced survival rate after birth of first calf (JimenezKrassel et al., 2015).

AMH is positively correlated with AFP (Ireland et al., 2009; Rico et al., 2009; Batista el al., 2014; Ribeiro et al., 2014) and oocyte yield (Majumder et al., 2010). Wiweko et al. (2016) 
reported that serum and follicular fluid AMH concentrations were also positively correlated with the total number of oocytes and number of mature oocytes. Takahashi et al. (2008) reported the concentration of AMH was higher in oocytes that were successfully fertilized compared to those that were not successfully fertilized. Therefore, AMH could be a reliable endocrine marker of both oocyte yield and quality (Takahashi et al. 2008; Lehman et al., 2014; Zhu et al., 2016). Further, it is tempting to suggest that replacement ewe lambs with a high concentration of AMH and a higher number of follicles (Ireland et al. 2009; Rico et al. 2009) will ovulate oocytes of better quality resulting in improved reproductive outcome.

In contrast, low concentration of $\mathrm{AMH}$ was not correlated with negative reproductive outcomes in humans aged 23 to 41 years (Streuli et al., 2014; Fraisse et al., 2008) and hamsters aged 9 months (Roosa et al., 2016). Smeenk et al. (2007) reported that basal AMH is not related to embryo quality or to the probability of achieving pregnancy in humans. This indicates that a single factor is not sufficient to predict pregnancy outcome across all species and physiological states.

In conclusion, a single measure of concentration of $\mathrm{AMH}$ of replacement females may be a useful tool to select replacement females with a high reproductive performance. However, it is important to consider breed when developing threshold values to delineate the potential for high and low reproductive outcome as the concentration of AMH varies among breeds of sheep, 
Table 3.1. Concentration of AMH used to classify animals as low, medium and high and total number of animals for experiment 1 and experiment 2.

\begin{tabular}{ccccc}
\hline Breed & \multicolumn{3}{c}{ Concentration of AMH $(\mathbf{p g} / \mathbf{m l})$} & N \\
\cline { 2 - 5 } & \multicolumn{2}{c}{ Low } & Medium & High \\
\\
\cline { 2 - 5 } Dorset & $<227(\mathrm{n}=89)$ & $227-447(\mathrm{n}=89)$ & $>447(\mathrm{n}=60)$ & 238 \\
\hline Katahdin & $<403(\mathrm{n}=24)$ & $403-728(\mathrm{n}=33)$ & $>728(\mathrm{n}=20)$ & 77 \\
\hline Suffolk & $<164(\mathrm{n}=17)$ & $164-311(\mathrm{n}=18)$ & $>311(\mathrm{n}=9)$ & 44 \\
\hline
\end{tabular}


Table 3.2. Effect of breed (Dorset/Texel Crosses, $n=238$ and Katahdin, $n=77$ ) and concentration of AMH (Low, Medium and High) on reproductive responses of replacement females. Values are least square means \pm SEM. Significant interaction $\mathrm{P}<0.05$.

\begin{tabular}{|c|c|c|c|c|c|c|c|}
\hline \multirow[t]{4}{*}{ Reproductive Variable } & \multicolumn{6}{|c|}{ Breed of Replacement female (B) } & \multirow[t]{3}{*}{ P-value } \\
\hline & \multicolumn{3}{|c|}{ Dorset/Texel Cross } & \multicolumn{3}{|c|}{ Katahdin } & \\
\hline & \multicolumn{6}{|c|}{ Concentration of AMH (pg/ml) } & \\
\hline & Low & Medium & High & Low & Medium & High & $\begin{array}{l}\text { Interaction } \\
\text { (B x AMH) }\end{array}$ \\
\hline Conception rate $(\%)^{\mathrm{a}}$ & $81.2 \pm 5.0$ & $84.1 \pm 4.9$ & $75.7 \pm 6.7$ & $41.6 \pm 11.9$ & $66.6 \pm 10.7$ & $90.0 \pm 13.0$ & 0.02 \\
\hline Pregnancy rate $(\%) 1^{\text {st }}$ service $^{b}$ & $61.8 \pm 5.3$ & $64.9 \pm 5.1$ & $46.4 \pm 6.3$ & $25.7 \pm 10.8$ & $34.2 \pm 9.0$ & $46.8 \pm 11.0$ & 0.07 \\
\hline Prolificacy $1^{\text {st }}$ service $^{c}$ & $1.34 \pm 0.08$ & $1.23 \pm 0.07$ & $1.32 \pm 0.1$ & $1.03 \pm 0.23$ & $1.04 \pm 0.17$ & $1.03 \pm 0.17$ & 0.09 \\
\hline Lambing to 1 st service $(\%)^{d}$ & $59.4 \pm 6.7$ & $68.1 \pm 6.1$ & $53.6 \pm 7.8$ & $31.5 \pm 13.6$ & $62.4 \pm 13.7$ & $90.6 \pm 15.4$ & 0.01 \\
\hline
\end{tabular}

\footnotetext{
${ }^{a}$ Number of replacement females diagnosed pregnant as a percentage of ewe lambs marked by rams

${ }^{b}$ Number of replacement females diagnosed on day 30 to 35 as a percentage of all ewe lambs exposed to rams

${ }^{c}$ Lambs born per replacement female lambing to the first service period (first 14 days of lambing season)

${ }^{\mathrm{d}}$ Proportion of replacement females lambing by day 14 of the lambing period
} 
Table 3.3. Main effects of breed (Dorset/Texel crosses, $n=238$ and Katahdin, $n=77$ ) and concentration of AMH (Low, Medium and High) on reproductive responses of replacement females. Significant difference $\mathrm{P}<0.05$.

\begin{tabular}{|c|c|c|c|c|c|c|c|}
\hline \multirow[t]{2}{*}{ Reproductive Response } & \multicolumn{2}{|c|}{ Breed of Replacement Female } & \multicolumn{3}{|c|}{ Concentration of AMH (pg/ml) } & \multicolumn{2}{|c|}{ P-Value } \\
\hline & Dorset/Texel Cross & Katahdin & $\begin{array}{l}\text { Low } \\
\text { (L) }\end{array}$ & $\begin{array}{l}\text { Medium } \\
\text { (M) }\end{array}$ & $\begin{array}{c}\text { High } \\
(\mathbf{H})\end{array}$ & Breed & $\begin{array}{r}\text { AMH } \\
\text { H vS. L }\end{array}$ \\
\hline Estrous Response $(\%)^{\mathrm{a}}$ & $71.5 \pm 3.0$ & $54.4 \pm 5.9$ & $67.8 \pm 5.5$ & $64.1 \pm 4.8$ & $56.9 \pm 5.9$ & 0.01 & NS \\
\hline Conception rate $(\%)^{b}$ & $80.3 \pm 3.2$ & $66.1 \pm 7.2$ & $61.4 \pm 4.4$ & $75.3 \pm 5.9$ & $82.8 \pm 7.3$ & 0.08 & 0.07 \\
\hline Pregnancy rate $(\%) 1^{\text {st }}$ service $^{c}$ & $57.7 \pm 3.3$ & $35.6 \pm 6.2$ & $43.8 \pm 5.9$ & $49.6 \pm 6.3$ & $46.6 \pm 6.3$ & 0.002 & NS \\
\hline Pregnancy rate $(\%) 2^{\text {nd }}$ service $^{d}$ & $82.3 \pm 2.7$ & $63.0 \pm 5.3$ & $74.2 \pm 5.0$ & $72.2 \pm 4.5$ & $71.5 \pm 5.3$ & 0.002 & NS \\
\hline Prolificacy $^{\mathrm{e}}$ & $1.18 \pm 0.04$ & $1.03 \pm 0.08$ & $1.11 \pm 0.07$ & $1.10 \pm 0.07$ & $1.09 \pm 0.07$ & 0.09 & NS \\
\hline 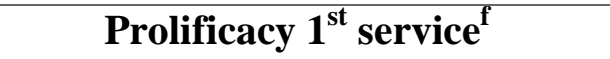 & $1.30 \pm 0.05$ & $1.03 \pm 0.11$ & $1.19 \pm 0.12$ & $1.13 \pm 0.09$ & $1.17 \pm 0.09$ & 0.03 & NS \\
\hline Lambing to 1st service $(\%)^{\mathrm{g}}$ & $60.4 \pm 4.0$ & $61.5 \pm 8.4$ & $45.5 \pm 7.5$ & $65.2 \pm 7.4$ & $72.1 \pm 8.6$ & NS & 0.04 \\
\hline Lambed (\%) & $68.7 \pm 3.1$ & $41.0 \pm 5.9$ & $60.5 \pm 5.5$ & $51.9 \pm 5.0$ & $52.1 \pm 6.0$ & $<0.001$ & $\mathrm{NS}$ \\
\hline Lambing rate $(\%)^{\mathrm{h}}$ & $83.9 \pm 4.2$ & $39.9 \pm 8.1$ & $68.2 \pm 7.6$ & $58.7 \pm 6.8$ & $58.7 \pm 8.1$ & $<0.001$ & NS \\
\hline Ram introduction to lambing $(d)^{i}$ & $155.9 \pm 0.9$ & $159.04 \pm 2.0$ & $160.7 \pm 1.7$ & $155.4 \pm 1.7$ & $156.3 \pm 2.0$ & NS & 0.08 \\
\hline Lambing day $(\mathbf{d})^{\mathbf{j}}$ & $14.6 \pm 0.9$ & $13.6 \pm 2.0$ & $17.4 \pm 1.8$ & $12.1 \pm 1.8$ & $12.8 \pm 2.0$ & NS & 0.08 \\
\hline Age to first lambing (d) & $398.61 \pm 1.71$ & $401.60 \pm 1.9$ & $403.3 \pm 1.7$ & $398.2 \pm 1.7$ & $398.8 \pm 2.0$ & NS & 0.08 \\
\hline
\end{tabular}


Table 3.4. The relationship between concentration of $\mathrm{AMH}$ and reproductive responses in Dorset/Texel crosses $(\mathrm{n}=238)$ and Katahdin breed $(n=77)$ ewe lambs. Values are least square means \pm SEM. Significant difference and interaction $P<0.05$.

\begin{tabular}{|c|c|c|c|c|c|c|c|}
\hline \multirow{4}{*}{$\begin{array}{c}\text { Reproductive Response } \\
\text { (RR) }\end{array}$} & \multicolumn{4}{|c|}{ Breed of Replacement Female } & \multicolumn{3}{|c|}{$\mathbf{P}$ - Value } \\
\hline & \multicolumn{2}{|c|}{ Dorset/Texel Cross } & \multicolumn{2}{|c|}{ Katahdin } & \multirow{3}{*}{$\begin{array}{l}\text { Reproductive } \\
\text { Response } \\
\text { (RR) }\end{array}$} & \multirow{3}{*}{$\begin{array}{l}\text { Breed } \\
\text { (B) }\end{array}$} & \multirow{3}{*}{$\begin{array}{c}\text { Interaction } \\
\text { (B X RR) }\end{array}$} \\
\hline & \multicolumn{4}{|c|}{$\begin{array}{c}\text { Incidence of Event } \\
\text { AMH Concentration }(\mathrm{pg} / \mathrm{ml})\end{array}$} & & & \\
\hline & Yes & No & Yes & No & & & \\
\hline Estrous Response & $316.30 \pm 18.7$ & $395.8 \pm 31.3$ & $559.2 \pm 40.8$ & $571.70 \pm 39.2$ & NS & $<0.001$ & NS \\
\hline Conception $^{\mathrm{a}}$ & $313.0 \pm 19.0$ & $355.5 \pm 39$ & $629.8 \pm 47$ & $365.5 \pm 64$ & 0.01 & 0.0006 & 0.0007 \\
\hline Pregnancy to $1^{\text {st }}$ service ${ }^{b}$ & $315.9 \pm 21.1$ & $384.7 \pm 25.3$ & $632.8 \pm 51$ & $519.0 \pm 37$ & NS & $<0.001$ & 0.009 \\
\hline Lambing to $1^{\text {st }}$ service & $330.4 \pm 24.3$ & $354.7 \pm 30.7$ & $683.3 \pm 52.7$ & $408.7 \pm 62.0$ & 0.005 & $<0.001$ & 0.0009 \\
\hline Lambed & $335.3 \pm 20.1$ & $362.5 \pm 30.4$ & $534.8 \pm 42.8$ & $573.2 \pm 45.5$ & NS & $<0.001$ & NS \\
\hline
\end{tabular}

${ }^{a}$ Number of replacement females diagnosed pregnant and marked by rams

${ }^{b}$ Number of replacement females diagnosed pregnant on day 30 to 35 of all ewes exposed to rams

${ }^{\mathrm{c}}$ Number of replacement females lambing by day 14 of the lambing period 
(a) Dorset Replacement Females

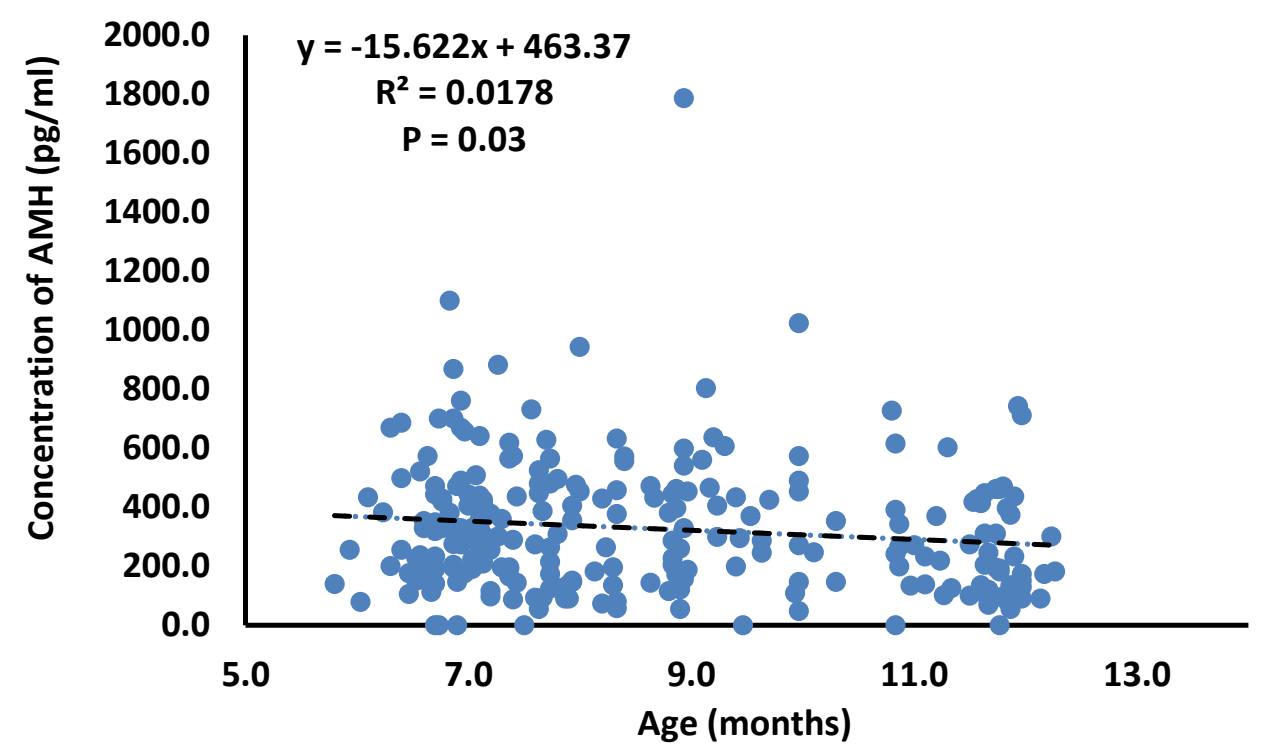

(b) Katahdin Replacement Females

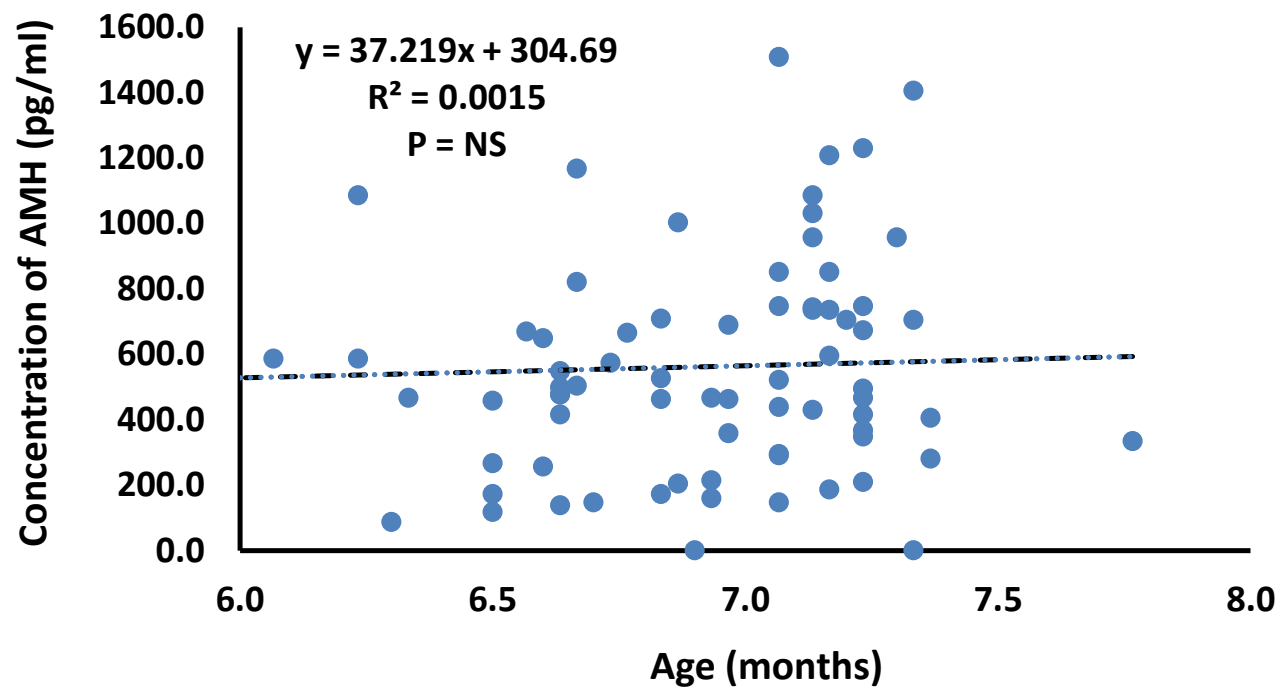

Figure 3.1. Effect of age on the concentration of AMH in (a) Dorset $(n=238)$ and (b) Katahdin $(n=77)$ replacement females. Each circle represents data from one ewe lamb. 


\title{
CHAPTER 4
}

\section{THE RELATIONSHIP BETWEEN THE CONCENTRATION OF AMH, AGE AND FOLLICLE GROWTH AND DEVELOPMENT IN WATER BUFFALOES \\ (Bubalus bubalis)}

\begin{abstract}
The concentration of anti-mullerian hormone $(\mathrm{AMH})$ and the relationship between $\mathrm{AMH}$, age and follicular growth and development in water buffaloes was evaluated. Two blood samples taken from cows and heifers $(\mathrm{N}=41$; age range: 1.5 to 22.3 years $) 6$ months apart were used to determine systemic concentration of $\mathrm{AMH}$, the repeatability of $\mathrm{AMH}$ and to assess the relationship between $\mathrm{AMH}$ and age. To determine the effect of $\mathrm{AMH}$ on follicular growth and ovulation, cows $(\mathrm{N}=20$; age: $5.5 \pm 0.43)$ with concentrations higher or lower than the mean were placed in the LOW and HIGH AMH groups, respectively. All animals were synchronized and follicular growth and development was monitored using transrectal ultrasonography. The mean concentration of AMH was $218 \pm 26$ and $194 \pm 30 \mathrm{pg} / \mathrm{ml}$ for samples 1 and 2, respectively. The within cow repeatability of concentration of AMH was 0.97. AMH generally increased until 10 years of age and then decreased (Quadratic effect: P < 0.001). Females with HIGH AMH had more large follicles $(\mathrm{P}=0.02)$ than females with LOW AMH. AMH did not affect the numbers of small, medium and total number of follicles. The diameter of the largest follicle was greater in animals with HIGH AMH $(\mathrm{P}=0.0004)$ than animals with LOW AMH. AMH did not affect the pattern of growth and development of follicles or other characteristics of the ovulatory cycle assessed. In conclusion, the concentration of $\mathrm{AMH}$ varies quadratically with age and does not affect the pattern of growth and development of follicles during the estrous cycle in water buffaloes.
\end{abstract}




\section{Introduction}

The water buffalo (Bubalus bubalis) is a significant livestock species in subtropical and tropical environments and are ideally suited for the production of meat and milk in these areas (Rastogi et al., 2004; Warriach et al., 2015). However, their productivity is limited due to inbreeding (Santana et al., 2011; Malhado et al., 2012), poor feeding management (Qureshi et al., 2007; Zicarelli, 2007), reproductive diseases such as brucellosis (Fosgate et al., 2011) and low reproductive performance (Singh et al., 2000). Reproductive performance of water buffaloes can be enhanced with the use of assisted reproductive technology (ART) techniques such as timed artificial insemination (TAI) superovulation and embryo transfer (Baruselli et al., 1994; Songasen et al., 1999; Techakumpu et al., 2001; Carvalho et al., 2002; Drost, 2007; Misra et al., 2007; Li et al., 2012). The success of ART in water buffaloes has been low (Madan et al., 1996; Neglia et al., 2010; Li et al., 2011) and variable (Gasparrini et al., 2014). Implementation of ART techniques requires knowledge and understanding about the ovarian cycle of water buffaloes and cyclical follicular growth and development (Henao et al., 2000; Ali et al., 2003; Vassena et al., 2003; Gimenes et al., 2011; Yindee et al., 2011; Singh et al., 2015).

Anti-Müllerian hormone $(\mathrm{AMH})$ is a $140-\mathrm{kDa}$ dimeric glycoprotein hormone belonging to the transforming growth factor- $\beta$ (TGF- $\beta$ ) family (Cate et al., 1986; Knight et al., 2006). AMH is expressed by granulosa cells and has been found to be a reliable endocrine marker of the size of the ovarian pool of antral follicles in humans (Visser et al., 2005), mice (Kevenaar et al., 2006) and cattle (Ireland et al. 2008; Rico et al., 2009; Monniaux et al., 2010; Batista et al., 2014; Souza et al., 2015; Batista et al., 2016). In addition, AMH is known to reduce primordial follicular activation and reduces the sensitivity of cells to FSH (Gruijters et al., 2003; Weenen et 
al., 2004; Visser et al., 2005). Both AMH and AFC decrease with increasing age (Ireland et al., 2008; Cushman et al., 2010; Monnaiux et al., 2013) and the production of quality oocytes following superovulation is known to decrease with age in cattle (Lerner et al., 1986; Breuel et al., 1991).

Neither the systemic concentration of $\mathrm{AMH}$, nor its relationship to age or follicular growth and development, have been fully investigated in water buffaloes. Therefore, the objectives of this study were to define the concentration of AMH in water buffaloes and its relationship to both age and the pattern of growth and development of follicles.

\section{Materials and Method}

Farm and Animals

This experiment was conducted at the Aripo Livestock Station located in Trinidad and Tobago (longtitude $61^{\circ} \mathrm{W}$ and latitiude $11^{\circ} \mathrm{N}$ ) with water buffaloes (Bubalus bubalis, N=41) ranging in age from 1.5 to 22.3 years. The buffaloes were maintained on pasture containing tanner (Brachiaria arrecta), bamboo (Chasmanthium latifolium), elephant (Pennisetum purpureum) and mulato grass (Brachiaria spp. Hybrids) with access to water ad libitum. All females were fed a commercial $16 \%$ crude protein $(\mathrm{CP})$ concentrate at a rate of 3 to $4 \mathrm{~kg} / \mathrm{day}$ for the duration of the study. 


\section{Experimental Protocol}

The systemic concentration and repeatability of plasma AMH was determined from two (2) blood samples collected 6 months apart. To determine the relationship between AMH and pattern of follicular growth and development and ovulation cows $(\mathrm{N}=20$; age: $5.5 \pm 0.43$ years $)$ with concentrations of AMH higher or lower than the mean in sample $2(194 \mathrm{pg} / \mathrm{ml})$ were placed in the HIGH and LOW AMH groups, respectively. The animals were placed on an estrus synchronization protocol as outlined in Figure 4.1. Briefly, all females received a controlled internal drug release device (CIDR, Pfizer Animal Health, New York, NY now Zoetis Animal Health, Kalamazoo, MI) containing $1.38 \mathrm{~g}$ of progesterone at insertion of device (Day 0). On day 6 all females were treated twice with $\mathrm{PGF}_{2 \alpha}(25 \mathrm{mg}$, i.m. Lutalyse 5 hours apart. On day 7 the CIDR was removed.

\section{Ultrasound Scanning}

To characterize the pattern of follicle growth, the ovaries was monitored beginning from CIDR removal for 28 days using transrectal ultrasonography (Aloka 500 Corometrics Medical Systems, Wallingford, Ct, USA with a 7.5 MHz linear transducer). Number and location of small (3 to $5 \mathrm{~mm}$ ), medium (5 to $10 \mathrm{~mm}$ ) and large $(>10 \mathrm{~mm}$ ) follicles on each ovary were recorded daily. 
Blood collection and AMH assay

Blood samples were collected into $10 \mathrm{ml}$ tubes containing EDTA by jugular venipuncture 6 months apart (January and June). The samples were immediately placed on ice and later centrifuged at $3000 \mathrm{X}$ g for 15 minutes to separate the plasma. Plasma samples were frozen at $20{ }^{\circ} \mathrm{C}$ for later analysis. Plasma AMH was determined using an enzyme-linked immunosorbent assay ELISA kit (ANSH Labs, Webster, Texas, USA). The sensitivity of the AMH assay was $1.1 \mathrm{pg} / \mathrm{ml}$ and intra-assay $\mathrm{CV}$ was $<5 \%$.

\section{Follicular Growth and Development}

The start of the estrous cycle was normalized in all water buffaloes to the day of ovulation following CIDR removal. Ovulation (day 0) was defined as the disappearance of a previously identified follicle greater than $10 \mathrm{~mm}$ from one ultrasound examination to the next (Lucy et al., 1991; Ravindra et al., 1994). The dominant follicle (DOF) was defined morphologically as the largest follicle exceeding the diameter of all the other follicles (Baruselli et al., 1997; Kulick et al., 1999). The second largest follicle (subordinate follicle - SOF) was the second largest follicle of all the other follicles (Baruselli et al., 1997). A dominant follicle and its cohort were defined as a wave (Knopf et al., 1989). The day of maximum diameter is the day at which the maximum diameter was obtained (Savio et al., 1988; Ginther, 2000). The length of the estrous cycle was defined as the number of days from one ovulation to the next (interovulatory interval; Peter et al., 2009). 


\section{Statistical Analysis}

To assess the repeatability of systemic AMH concentrations in water buffaloes the correlation between AMH in blood samples taken from the same animal six months apart was determined using the PROC REG procedure of SAS (Statistical Analysis System version 9.4 for Windows; SAS Institute, Cary, NC, USA). A polynomial regression was used to assess the relationship between concentration of AMH and age in water buffaloes using the PROC REG procedures of SAS.

The populations of small, medium and large follicles, and the diameter of the largest (dominant) and second largest (subordinate) follicle over time were analyzed using repeated measures PROC MIXED. The model included the fixed effect of AMH category (HIGH and LOW), day and AMH category $\mathrm{x}$ day interaction with day as the repeated term. The autoregressive heterogeneous structure was utilized to estimate the covariance. The slope responses for day (i.e. linear vs. quadratic effects) and their interaction with main effects were assessed using a polynomial contrast - using the same model, except that day was considered to be a continuous variable (Al-Trad et al., 2010). Results were considered significant at a confidence level of $\mathrm{P} \leq 0.05$ and a tendency when $0.05<\mathrm{P} \leq 0.1$.

To assess the effect of the concentration of AMH on the characteristics of follicular development during the estrous cycle, a one way analysis of variance (ANOVA) was conducted using PROC MIX procedure of SAS and means were separated using Tukey's HSD. The main effect of concentration of AMH was determined for day of maximum diameter, day of second maximum diameter, size of first ovulatory follicle, size of second ovulatory follicle, day of ovulation and interovulatory interval. 


\section{Results}

Concentration of AMH in water buffaloes

The mean concentration of AMH was $218 \pm 26$ and $194 \pm 30 \mathrm{pg} / \mathrm{ml}$ for the 1 st and $2 \mathrm{nd}$ blood samples, respectively. Concentration of AMH ranged from 6 to $715 \mathrm{pg} / \mathrm{ml}$. The within cow repeatability of concentration of AMH was 0.97 (Figure 4.2).

Concentrations of AMH changed quadratically with increasing age (Figure 4.3; quadratic effect, $\mathrm{P}<0.001)$. Concentration of AMH generally increased until 10 years of age and then decreased thereafter.

Effect of concentration of AMH on growth and development of ovarian follicles during the estrous cycle

The numbers of small, medium and large follicles (Figure 4.4; $\mathrm{P}<0.001$ ) and total number of follicles (Figure 4.5; $\mathrm{P}=0.02$ ) varied with day of the estrous cycle. The diameter of the largest and second largest diameter follicle changed cubically with day. (Figure 4.7b; cubic effect $\mathrm{P}=0.03$ and $\mathrm{P}=0.03$, respectively).

Water buffaloes in the HIGH AMH group had more large follicles (Figure 4.6; P = 0.02) than animals in the LOW AMH group. AMH group did not affect the numbers of small, medium and total number of follicles. The AMH group $\mathrm{x}$ Day interaction was not significant for the numbers of small, medium, large and total number of follicles. 
The maximum diameter of the dominant follicle was greater in cows in the HIGH AMH group than those in the LOW AMH group (Figure 4.7a; $\mathrm{P}=0.0004$ ). AMH did not affect the

diameter of the $2^{\text {nd }}$ largest diameter. The AMH x Day interaction was not significant for largest and second largest diameter of follicles. Other characteristics of follicle growth and development and the ovarian cycle were not affected by AMH. (Table 4.1)

\section{Discussion}

There are limited reports on the relationship between concentration of AMH and follicular growth and development of ovarian follicles or the relationship between the concentration of AMH and age in water buffaloes (Bubalus bubalis). The present study demonstrated that in water buffaloes (i) the within cow repeatability of concentration of AMH was high and almost close to 1 (ii) the concentration of $\mathrm{AMH}$ varies quadratically with age (iii) and water buffaloes with a high concentration of $\mathrm{AMH}$ had a greater number of large follicles and greater maximum diameter of follicles.

The mean concentration of AMH in water buffaloes that were between 1.6 to 22.3 years old was 218 and $193 \mathrm{pg} / \mathrm{ml}$ for the first and second blood samples, respectively, with a range of 6 to $715 \mathrm{pg} / \mathrm{ml}$. The mean concentration reported in the present study was similar to $175 \mathrm{pg} / \mathrm{ml}$ reported for water buffalo heifers at 24 to 30 months (Baldrighi et al., 2014). However the mean value reported in the present study, was lower than that reported of Bos taurus (239 - 320 pg/ml; Guerreiro et al., 2014; Batista et al., 2014; Baldrighi et al., 2014) and Bos indicus (605 1000 pg/ml; Guerreiro et al., 2014; Batista et al., 2014; Baldrighi et al., 2014; Ribereiro et al., 2014) cattle. The low AMH concentration observed in the present study and that of Baldrighi's study, might be due in part to the lower number of primordial and antral ovarian follicles 
reported in water buffaloes (Van Ty et al., 1989; Baruselli et al., 1997; Gimenes et al., 2009). The lower number of follicles may be due to the great amount of atretic follicles present in the Bubalus bubalis ovary (Mondadori et al., 2007; 2010) and the decreased proliferative activity of granulosal and thecal cells associated with these atretic follicles (Isobe et al., 2000; Feranil et al., 2004). In addition, because AMH is primarily produced in the granulosa cells (Rico et al., 2012; Monniaux et al., 2013), the decreased proliferation results in lower follicular growth and development, which may contribute to the low antral follicular count resulting in low AMH.

AMH concentrations in the present study ranged from 6 to $715 \mathrm{pg} / \mathrm{ml}$. Wide range of AMH values have also been reported for Bos taurus and Bos indicus cattl, 60 to 570, 410 to 1200 pg/ml, respectively, (Batista et al., 2014; Guerreiro et al., 2014; Ribereiro et al., 2014; Baldrighi et al., 2014) Rasa Aragonesa (0 to 590 pg/ml; Lahoz et al., 2012) and Dorset, Suffolk and Katahdin sheep (47 to 1100,47 to 661 and 87 to $1510 \mathrm{pg} / \mathrm{ml}$ ), respectively; Redhead et al., unpublished data). Baldrighi et al. (2014) reported a relatively narrow range of values (110 to $320 \mathrm{pg} / \mathrm{ml}$ ) in water buffaloes which might have been related to the narrow age range (24 to 30 months) used in that study.

In the present study, the within cow repeatability was 0.97. Similarly, Rico et al. (2009) analyzed AMH concentration at time points 3 months apart in Holstein dairy cattle and reported that the within cow repeatability was 0.87 . This indicates that intra-animal concentration of AMH does not change significantly during the short to medium term.

AMH concentration varied quadratically with age of water buffalo. In this study, concentration of AMH generally increased until 10 years of age and then decreased thereafter. Similarly, AMH was shown to change quadratically with increasing age in human (Hudson et al., 1990; Visser et al., 2013). In beef cows, systemic concentration of AMH changed quadratically 
with age, increasing until 5 years then decreasing (Cushman et al., 2009; 2010). In contrast, some studies in women (Fanchin et al., 2003; van Rooij et al., 2005) and cattle (Ireland et al., 2008) reported a negative linear relationship between concentration of $\mathrm{AMH}$ and age. Additionally, Erickson et al. (1966) reported that in cattle, the reduction in AFC was related to the reduction in the size of the ovarian reserve over time. The contrasting observations on the relationship between AMH and age might be related in part to differences in the range in age of females used in the studies. Studies using a wide age range would allow the concentration of AMH to be evaluated when the AFC would be expected to be both increasing and decreasing (Cushman et al., 2009; 2010). AMH in females is primarily produced by the granulosal cells of the ovarian follicle and concentration of $\mathrm{AMH}$ is positively correlated with antral follicle count (AFC) in mice (Durlinger et al., 2002a), women (Fanchin et al., 2003), Bos taurus and Bos indicus cattle (Batista et al., 2014; Batista et al., 2016; Souza et al., 2015; Rico et al., 2009; Ireland et al., 2008) and in water buffaloes (Baldrighi et al., 2014). The relationship between concentration of AMH and age observed in water buffaloes in this study is probably reflective of the changes in the population of antral follicles.

Water buffaloes with a high concentration of $\mathrm{AMH}$ had a greater number of large follicles and a greater maximum diameter. Systemic AMH concentrations have been shown to be positively correlated with the number of antral follicles in humans (Van Rooij et al., 2002; Gruijters et al., 2003) and cattle (Ireland et al., 2008; Rico et al., 2009; Batista et al., 2014; Ribereiro et al., 2014; Baldrighi et al., 2014; Souza et al., 2015; Batista et al., 2016; StojsinCarter et al., 2016). For example, Baldrighi et al. (2014) reported that heifers with high AMH had a greater AFP than heifers with low AMH in water buffaloes and cattle. Water buffaloes with a high concentration of $\mathrm{AMH}$ would have a greater size of ovarian reserve resulting in a 
greater number of primordial follicles recruited in the preantral and antral stages. As a result, there are a greater number of small follicles available for the transition into medium and large follicles. Batista et al. (2014) reported that high concentrations of AMH were associated with an increase in the number of ovarian antral follicles and suggested that it may be the high concentration of AMH contributed to lower rates of follicular atresia.

Despite the occurrence of cyclical patterns of growth and development of follicles during the ovarian cycle, minimal variation in AMH have been observed during the menstrual cycle in humans (Hehenkamp et al., 2006; La Marca et al., 2006) and the estrous cycle in cattle (Ireland et al., Rico et al., 2011; Pfeiffer et al., 2014). However, in rats, Baarends et al. (1995) reported that AMH and AMHRII mRNAs decreased at estrus and suggested that the FSH surge observed on the morning of estrus may cause a decrease in the level of ovarian AMH mRNA and perhaps AMHRII mRNA. In the present study, AMH did not affect the pattern of growth and development during the estrous cycle.

In conclusion, the concentration of AMH in water buffaloes varies quadratically with age. Since a high repeatability in the intra-animal systemic concentration of AMH exist, a single blood sample can be used to make reproductive decisions with reference to a specific animal. The concentration of AMH does not affect the pattern of growth and development during the estrous cycle in water buffaloes except for size of largest follicle. 
Table 4.1. Effect of concentration of AMH (Low vs. High) on the characteristics of follicular growth and development in water buffaloes $(n=20)$ during the estrous cycle. Values are least square means \pm SEM. Significant difference $\mathrm{P}<0.05$.

\begin{tabular}{|c|c|c|c|}
\hline \multirow[t]{2}{*}{ Characteristic } & \multicolumn{2}{|c|}{ Concentration of AMH (pg/ml) } & \multirow[t]{2}{*}{ P-Value } \\
\hline & Low & High & \\
\hline Size of first ovulatory follicle (cm) & $1.27 \pm 0.1$ & $1.24 \pm 0.09$ & 0.8 \\
\hline Size of second ovulatory follicle $(\mathrm{cm})$ & $1.07 \pm 0.06$ & $1.16 \pm 0.06$ & 0.4 \\
\hline Day of largest diameter of follicle & $15.0 \pm 1.9$ & $13.5 \pm 1.7$ & 0.6 \\
\hline Day of $2^{\text {nd }}$ largest diameter of follicle & $15.8 \pm 1.8$ & $14.4 \pm 1.6$ & 0.6 \\
\hline Interovulatory period (days) & $20.2 \pm 0.9$ & $18.6 \pm 0.9$ & 0.2 \\
\hline
\end{tabular}




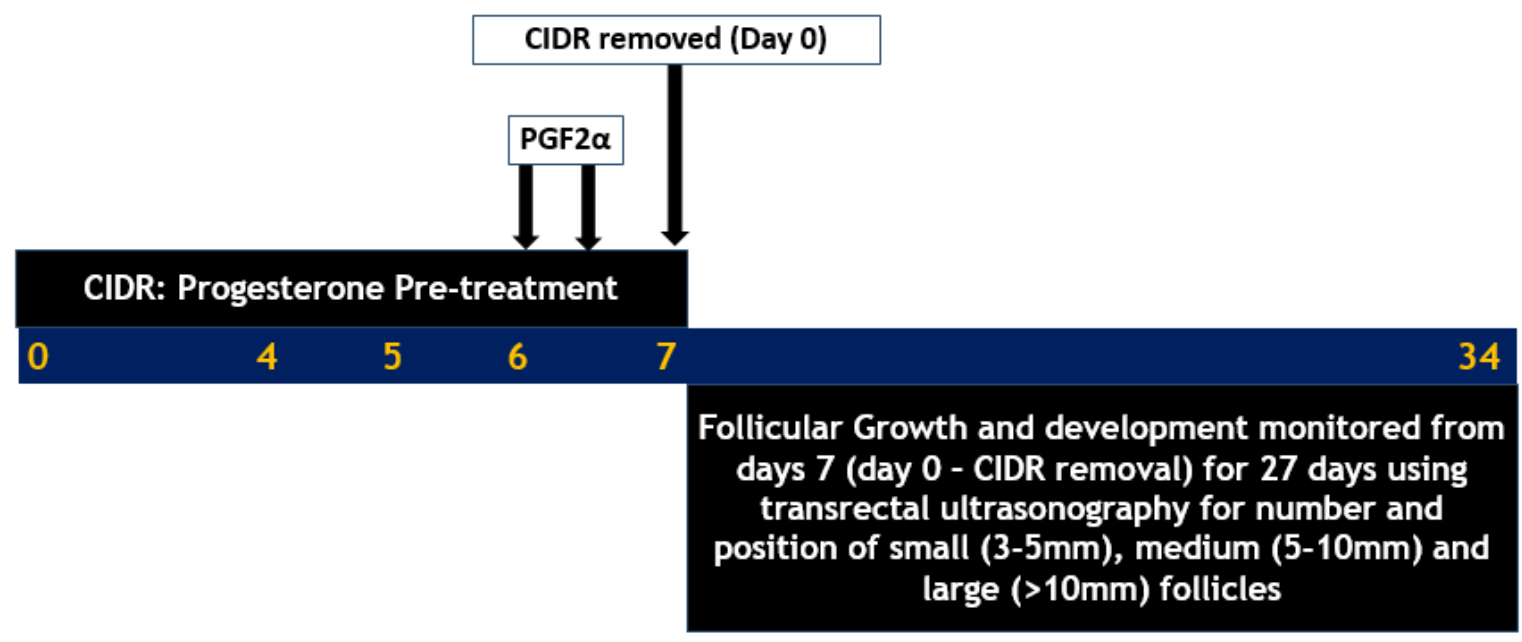

Figure 4.1. Estrus synchronization protocol. 


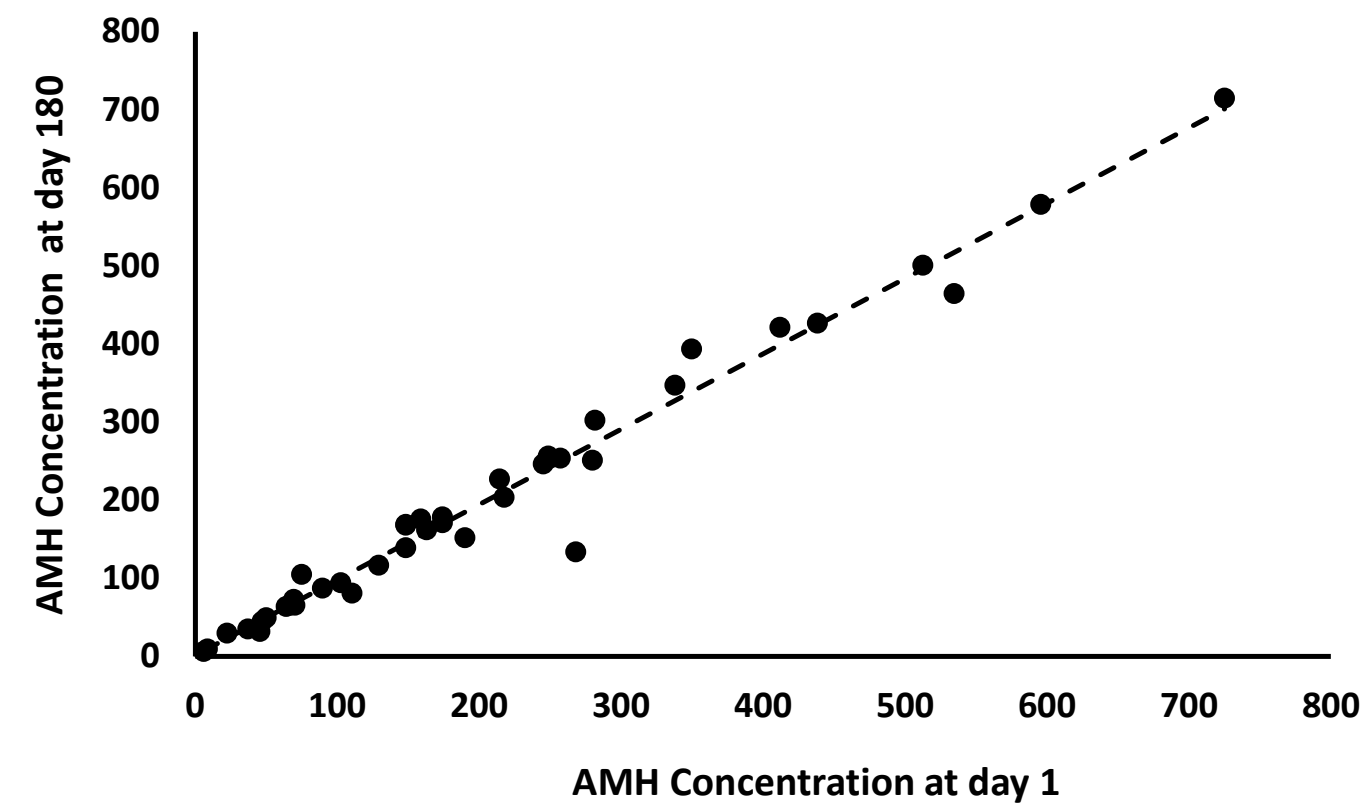

Figure 4.2. Regression Plot of anti-Mullerian hormone (AMH) concentrations 6 months apart in 20 water buffaloes (Bubalus bubalis). Linear regression equation: $\mathrm{y}=0.965 \mathrm{x}+1.5758$. The coefficient of determination and the average $\mathrm{CV}$ between samples were 0.97 and $<5 \%$. 


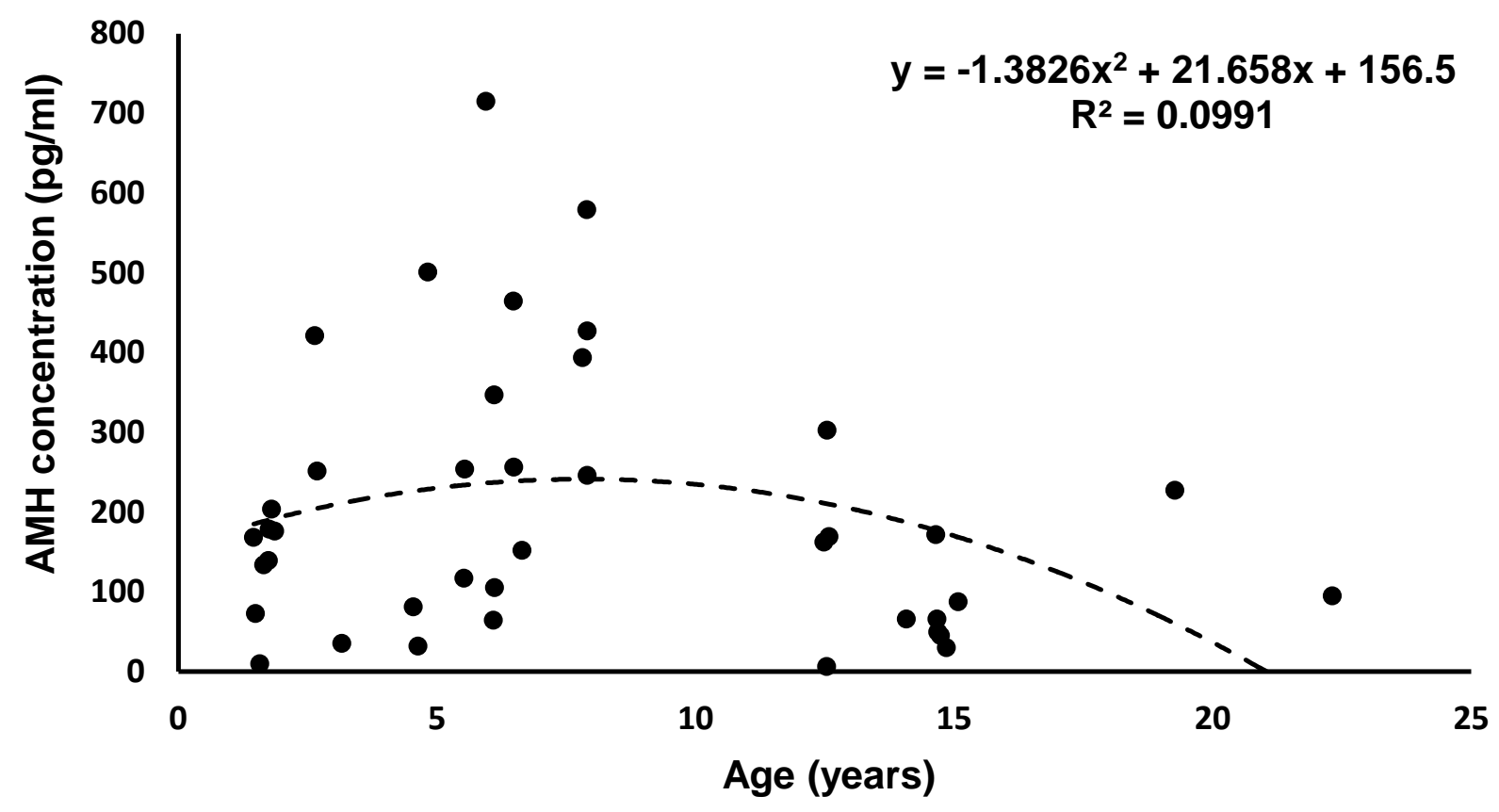

Figure 4.3. Regression of concentration of AMH on age in water buffaloes (Bubalus bubalis, $\mathrm{n}=$ 41) between the ages 0 to 22 years. As age increased, there was a quadratic effect concentration of AMH $(\mathrm{P}<0.05)$ such that the concentration increased until 10 years of age and decreased thereafter. 


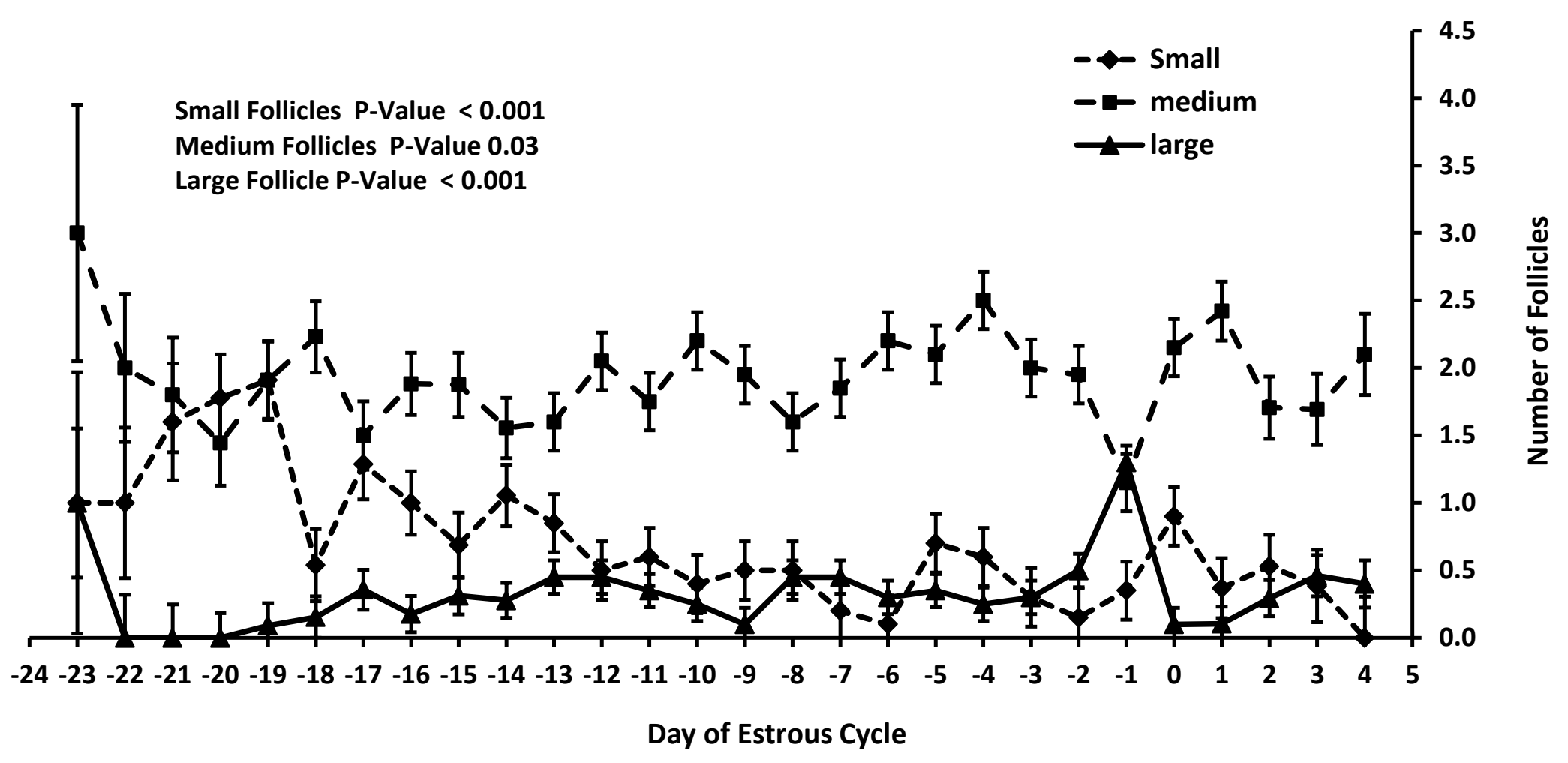

Figure 4.4. Growth and development of ovarian follicles, small $(3-5 \mathrm{~mm})$, medium $(5-10 \mathrm{~mm})$ and large $(>10 \mathrm{~mm})$ of water buffaloes (Bubalus bubalis, $\mathrm{n}=20$ ) during the estrous cycle (Day $0=$ day of ovulation). Values are least square means \pm SEM. Significant day effect $\mathrm{P}<0.05$. 


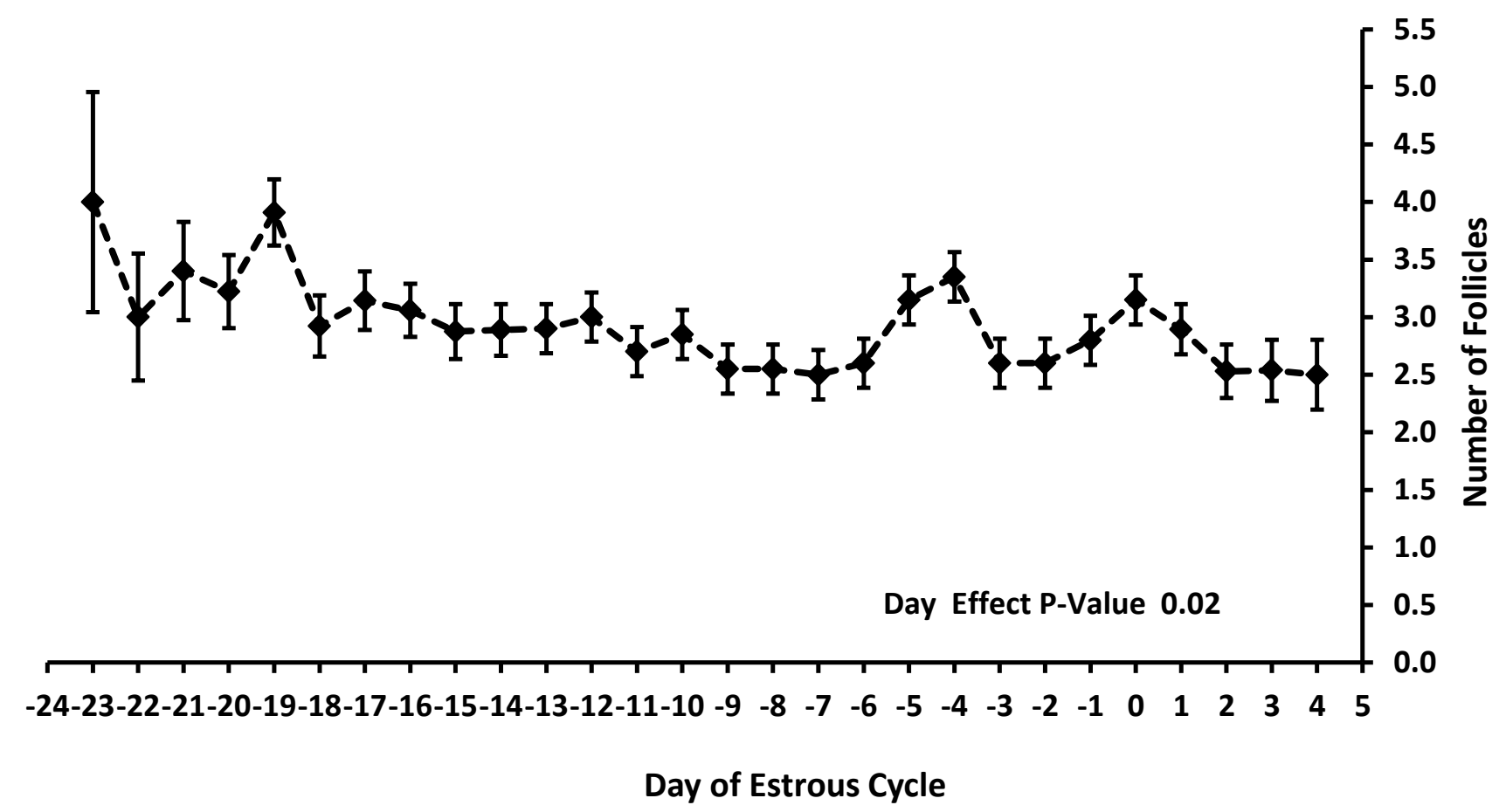

Figure 4.5. Average daily total numbers of follicles of water buffaloes (Bubalus bubalis, $\mathrm{n}=20$ ) during the estrous cycle (Day $0=$ day of ovulation). Values are least square means \pm SEM. Significant day effect $\mathrm{P}<0.05$. 


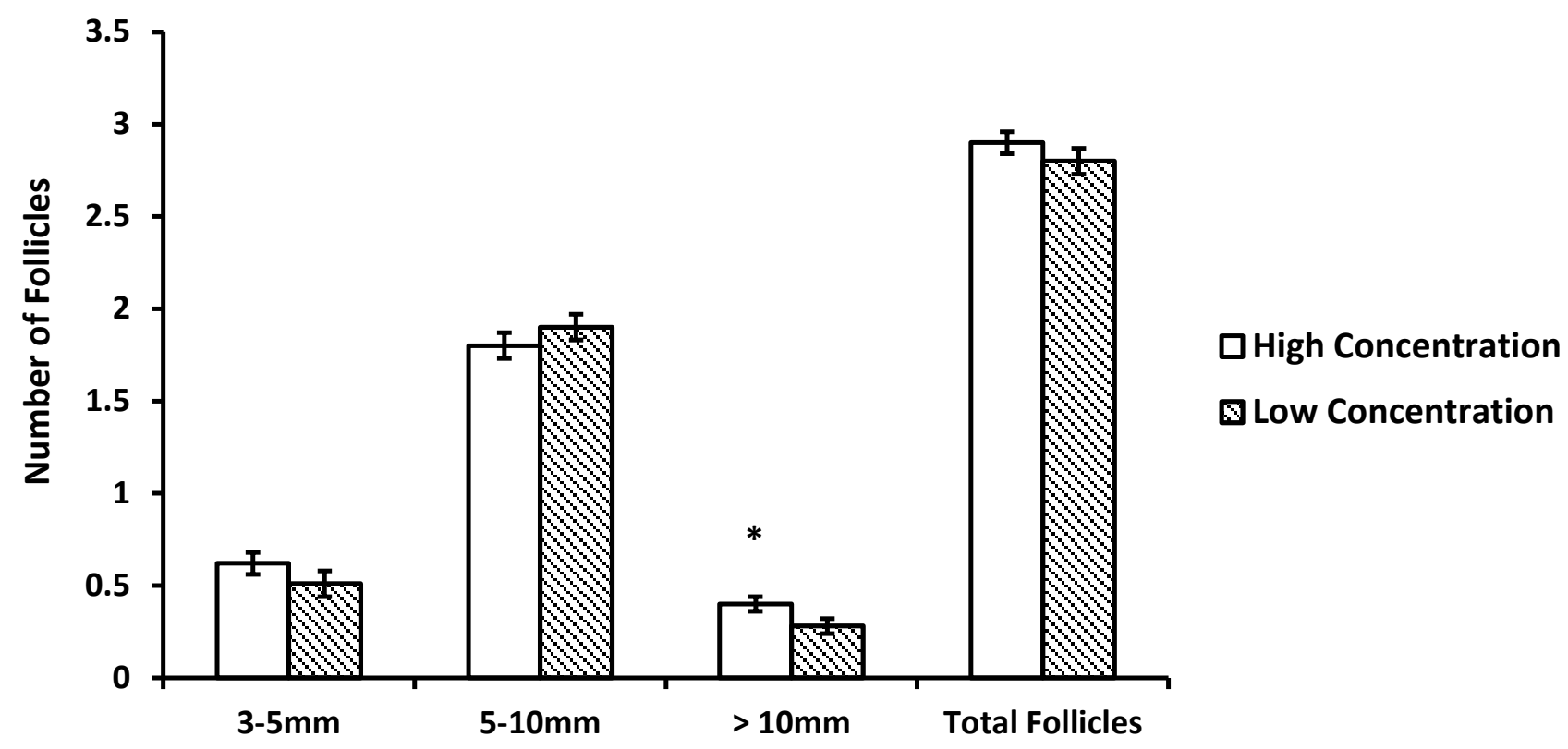

Figure 4.6. Effect of concentration of AMH (Low vs. High) on the average daily number of small $(3-5 \mathrm{~mm})$, medium $(5-10 \mathrm{~mm})$, large $(>10 \mathrm{~mm})$ follicles and total number of follicles in water buffaloes (Bubalus bubalis, $\mathrm{n}=20$ ) during the estrous cycle. Values are least square means \pm SEM. *P $<0.05$, compared with cows with low concentration of AMH. 
(a) Concentration of $\mathrm{AMH}$

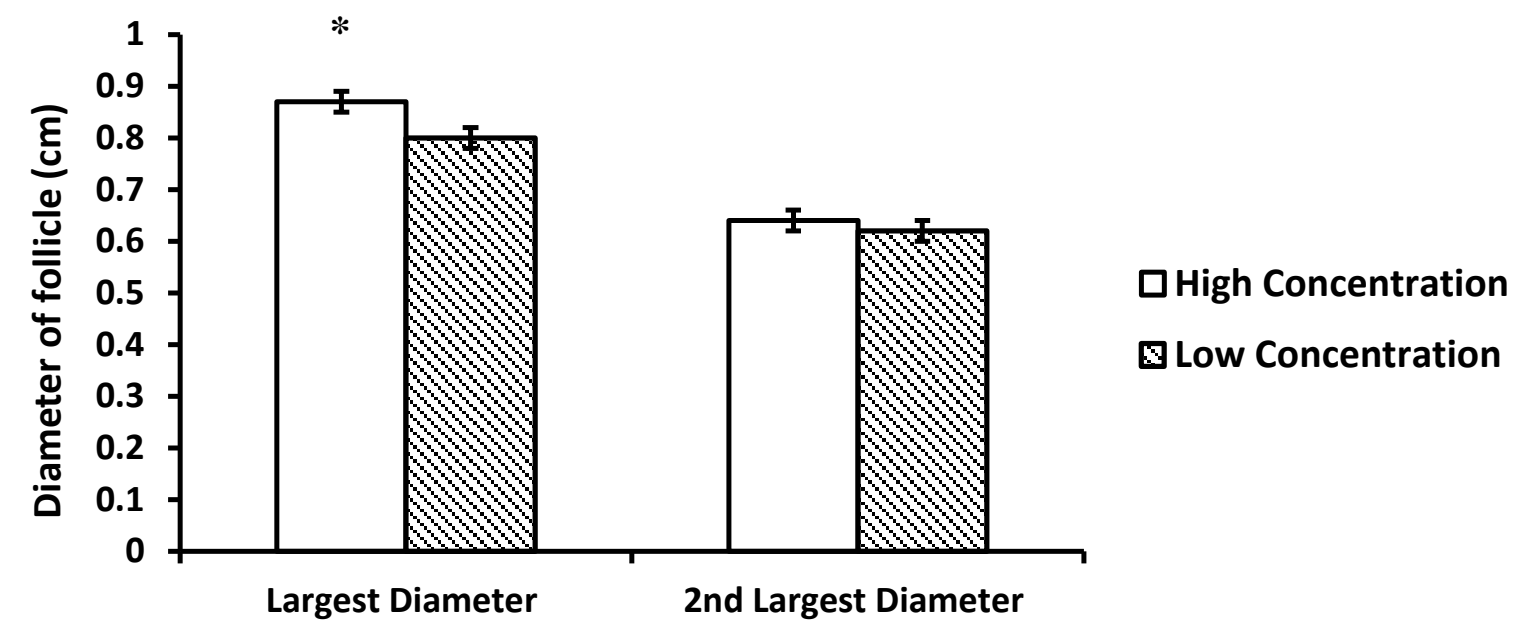

(b) Day

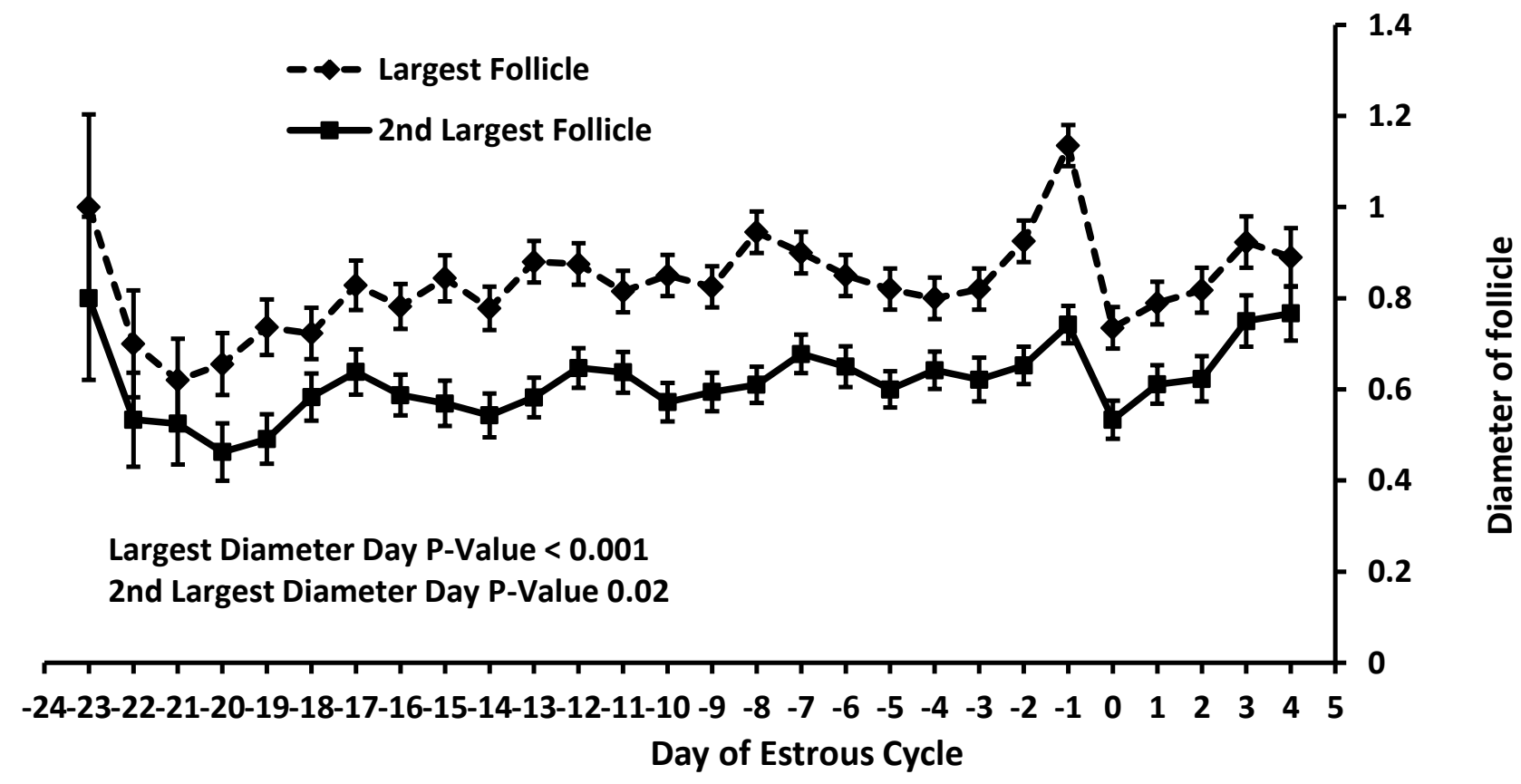

Figure 4.7. Effect of (a) concentration of AMH (Low vs. High) and (b) day on the largest diameter and second largest diameter of follicle of water buffaloes (Bubalus bubalis, $\mathrm{n}=20$ ) during the estrous cycle (Day of ovulation $=0$ ). Values are least squares means $\pm \mathrm{SEM}$. *P < 0.05 , compared with cows with low concentration of AMH. Significant day effect $\mathrm{P}<0.05$. 


\title{
CHAPTER 5
}

\section{THE EFFECT OF CIRCULATING CONCENTRATION OF AMH AND TYPE OF FOLLICLE STIMULATING HORMONE (FSH) ON FOLLICLE GROWTH AND OVULATORY RESPONSE TO SUPEROVULATION IN WATER BUFFALOES (Bubalus bubalis)}

\begin{abstract}
The relationship between circulating concentration of anti-mullerian hormone (AMH) and type of follicle stimulating hormone (FSH) preparation on follicular growth and ovulatory response in water buffaloes was evaluated. A single blood sample was taken from cows $(\mathrm{N}=31$; age: $9.06 \pm$ 0.98 years) to determine systemic AMH. Animals with concentrations higher or lower than $194 \pm$ $30 \mathrm{pg} / \mathrm{ml}$ were placed to LOW and HIGH AMH groups and were assigned randomly to be superovulated with either FSHp (high LH content) or Folltropin V (low LH content). Follicular growth and ovulation were monitored using transrectal ultraonography. In animals with HIGH systemic AMH, FSHp increased the numbers of small follicles. The type of FSH preparation had no effect on the number of small follicles in animals with low AMH (AMH x FSH; P = 0.02). Females with a HIGH AMH had a greater numbers of small follicles $(\mathrm{P}=0.01)$ and total follicles $(\mathrm{P}=0.005)$ than those with LOW AMH. Females treated with FSHp had more small follicles (P $=0.001)$ and fewer large $(\mathrm{P}<0.001)$ and total follciles $(\mathrm{P}=0.0005)$ than those treated with Folltropin V. In animals with HIGH AMH, Folltropin V increased the number of ovulated follicles $(\mathrm{AMH} \times \mathrm{FSH} ; \mathrm{P}=0.03)$. Females with HIGH AMH $(\mathrm{P}=0.05)$ and those treated with Folltropin V $(\mathrm{P}<0.001)$ ovulated more follicles than those with LOW AMH and those treated with FSHp, respectively. In conclusion, selecting animals with high AMH concentration and the use of FSH preparations with a lower LH content may improve the superovulatory response in water buffaloes.
\end{abstract}




\section{Introduction}

Water buffaloes are ideally suited for the production of meat and milk in developing countries (Rastogi et al., 2004; Warriach et al., 2015). However, improvement and distribution of superior water buffalo genetics has been slow due to the limited use of reproductive management techniques and poor yields of oocytes and embryos following superovulation treatments. In cattle, the number of ova/embryos recovered and the transferable yield following superovulation varies between 8-12 and 4-6 respectively (Lerner et al., 1986; Breuel et al., 1991; Bo et al., 2014; Hasler, 2014; Gabriel et al., 2014; Silva-Santos et al., 2014; Souza et al., 2014). In contrast, the average number of recoverable embryos derived from using similar superovulatory protocols has been less than 2 in water buffaloes (Madan et al., 1996; Carvalho et al., 2002; Neglia et al., 2003; Drost et al., 2007; Li et al., 2011) and in Mediterranean (Neglia, 2010) and Swamp (Songasen et al., 1999; Techakumpu et al., 2000) buffaloes. Additionally, the application of superovulation treatments has been limited by high among animal variability (Govignon et al., 2000; Gasparrini et al., 2014).

A major determinant of responsiveness to superovulation treatments is the number of healthy follicles that are available in the follicular pool. Water buffaloes exhibit fewer primordial (Danell, 1987) and antral (Baruselli et al., 1997) follicles in comparison to cattle. Ultrasonographic determination of the antral follicle count (AFC) has been shown to be correlated with subsequent response to superovulation in cattle (Ireland et al., 2007), but may not be reliable due to different skills of operators, types of machine, criteria used to determine AFC and stage of follicular wave at time of observation (Burns et al., 2005; Monnaiux et al., 2010). Therefore, the use of an alternative predictor of superovulatory response may be beneficial. 
Anti-Müllerian hormone (AMH) is a $140-\mathrm{kDa}$ dimeric glycoprotein hormone that belongs to the transforming growth factor- $\beta$ (TGF- $\beta$ ) family (Cate et al., 1986; Knight et al., 2006). It is expressed by granulosal cells and has been found to be a reliable endocrine marker of the size of the ovarian follicle pool in humans (Visser et al., 2005), mice (Kevenaar et al., 2006) and cattle (Ireland et al., 2008; Rico et al., 2009; Monniaux et al., 2010; 2012; Batista et al., 2016). AntiMullerian hormone is known to play a critical role in folliculogenesis by modulating follicle stimulating hormone (FSH) function (Weenen et al., 2004; Bentzen et al., 2013).

A strong positive correlation exists between concentration of AMH and superovulatory response as measured by ovulation and embryo recovery rate in cattle (Monniaux et al., 2010; Rico et al., 2012; Vernunft et al., 2015; Souza et al., 2014; Hirayama et al., 2016), goats (Monniaux et al., 2011) and sheep (Lahoz et al., 2014; Garcia Salas et al., 2017). This relationship has allowed the concentration of AMH to be used as a predictive endocrine marker of ovulation and embryo recovery rates following superovulation (Guerreiro et al., 2014; Souza et al., 2014; Batista et al., 2016). In water buffaloes, the relationship between the concentration of AMH and superovulatory response has not been fully established. The yield of transferable embryos is also influenced by age and parity (Breuel et al., 1991; Lerner et al., 1986; Hasler, 2014) and the circulating concentration of AMH is inversely related to age in humans (van Rooij et al., 2005; Rosen et al., 2012) and cattle (Batista et al., 2016; Jimenez-Krassel et al., 2015).

The follicle stimulating hormone (FSH) preparation used in the protocol affected the response to superovulation treatments (Madan et al., 1996; Kafi et al., 1997; Hasler, 2014). For example, high LH content (low FSH/LH ratio) negatively affected the superovulatory response, fertilization rate and embryo recovery in water buffaloes (Murphy et al., 1984) and cattle (Greve et al., 1995; Kelly et al. 1997). Conversely, in cattle studies, donors treated with FSH 
preparations with low LH content had more viable embryos, total number of ova recovered and higher fertilization rate (Chupin et al., 1984; Mapletoft et al., 1988; Lopes de Costa et al., 2001; Quaresma et al., 2003). Few studies have explored the effect of different FSH preparations on follicle growth and superovulatory response in water buffaloes (Techakumphu et al., 2000; Singh et al. 2015).

Due to the low and variable response in water buffaloes and the high cost of superovulation treatments, the ability to predict females that will show a high and repeatable response to superovulation treatments is needed to preserve superior genetics. Therefore, the objective of this study was to determine the relationship between circulating concentrations of AMH and type of FSH preparation on follicle growth and ovulatory response in water buffaloes.

\section{Materials and Method}

\section{Materials}

The procedures used in these studies were approved by the West Virginia University Animal Care and Use Committee (IACUC \#13-120). Follicle stimulating hormone (11.4\% LH; Amstrong et al., 1986) from porcine pituitary (FSHp; product number F2293) and estradiol 3 benzoate (product number E8515) was obtained from Sigma Aldrich Chemicals, USA. Folltropin V (2.5\% LH; Armstrong et al., 1986) was obtained from Vetoquinol, Canada. 17- $\alpha$ hydroxyprogesterone caproate (17-OHP) was obtained from Abcam Biochemicals, USA. The Controlled Internal Drug Release Device (CIDR) was obtained from Pfizer Animal Health, New York, NY (now Zoetis Animal Health, Kalamazoo, MI). PGF $2 \alpha$ (Lutalyse) was obtained from 
Pfizer Animal Health, New York, NY (now Zoetis Animal Health, Kalamazoo, MI). Gonadotropin releasing hormone (gonadorelin diacetate tetrahydrate; $\mathrm{GnRH}$ ) was obtained from Merial LLC, Duluth, GA. Stock solutions of estradiol $(333 \mu \mathrm{g} / \mathrm{ml})$ and progesterone (50 mg per ml) were prepared for use.

Farm and Animals

The experiment was conducted at the Aripo Livestock Station located in Trinidad and Tobago (longtitude $61^{\circ} \mathrm{W}$ and latitiude $11^{\circ} \mathrm{N}$ ). Water buffaloes (Bubalus bubalis, $N=31$ ) with ages ranging from 2 to 22 years were used in this study. The buffaloes were maintained on pasture containing tanner (Brachiaria arrecta), bamboo - (Chasmanthium latifolium), elephant (Pennisetum purpureum) and mulato (Brachiaria spp. Hybrids) grasses with access to water ad libitum. All females were fed a commercial $16 \%$ crude protein $(\mathrm{CP})$ concentrate at a rate of 3 to $4 \mathrm{~kg} /$ day for the duration of the study.

\section{Experimental Protocol}

To test the effects of concentration of $\mathrm{AMH}$ on follicular growth and ovulation, the systemic concentration of AMH was determined from one (1) blood sample taken from each cow $(\mathrm{N}=31$; age: $9.06 \pm 0.98$ years). Females with concentrations of AMH higher or lower than the mean concentration $(194 \pm 30 \mathrm{pg} / \mathrm{ml})$ were placed in the LOW (mean: $84 \pm 12 \mathrm{pg} / \mathrm{ml})$ and HIGH (mean: $396 \pm 40 \mathrm{pg} / \mathrm{ml}$ ) AMH groups, respectively. To determine the effects of different types of FSH preparations, cows within the HIGH and LOW AMH groups were randomly assigned to be 
superovulated using an equivalent amount of NIH-FSH-P1 as either FSHp (11.5\% LH) or Folltropin V (2.5\% LH). The superovulation protocol is outlined in Figure 1. Briefly, each female received a controlled internal drug release device containing $1.38 \mathrm{~g}$ of progesterone and was injected with $1 \mathrm{mg}$ estradiol benzoate and $350 \mathrm{mg}$ progesterone (i.m.) at insertion of device (Day 0). Beginning on day 4 through day 7 , animals were injected twice daily with decreasing doses of their assigned follicle stimulating hormone (FSH) preparation (80, 80, 60, 60, 40, 40, 20 and $20 \mathrm{mg}$ of NIH-FSH-P1 equivalent on days, 4, 5, 6 and 7 respectively). At the times of the $6^{\text {th }}$ and $7^{\text {th }}$ doses, all females were treated with $\mathrm{PGF}_{2 \alpha}(25 \mathrm{mg}$, Lutalyse ;i.m.). On day 7 the CIDR was removed and each animal was injected with $2 \mathrm{mls}$ Cystorelin $(100 \mu \mathrm{g}$ gonadotropin releasing hormone - $\mathrm{GnRH})$.

Blood collection and AMH assay

Blood samples were collected into $10 \mathrm{ml}$ tubes containing EDTA by jugular venipuncture at the start of the synchronization and superovulation protocols. The samples were immediately placed on ice and later centrifuged at $3000 \mathrm{X} \mathrm{g}$ for $15 \mathrm{~min}$ to harvest plasma. The plasma samples were frozen at $-20^{\circ} \mathrm{C}$ for later analysis. Plasma AMH was determined using an enzymelinked immunosorbent assay ELISA kit (ANSH Labs, Webster, Texas, USA). The sensitivity of the $\mathrm{AMH}$ assay was $1.1 \mathrm{pg} / \mathrm{ml}$ and intra-assay $\mathrm{CV}$ was $<5 \%$.

\section{Ultrasound Scanning}


To monitor follicle growth and development, and ovulation the ovaries were monitored on days 4 to 11 using transrectal ultrasonography (Aloka 500 Corometrics Medical Systems, Wallingford, Ct, USA with a 7.5 MHz linear transducer). Number and location of small (3 to 5 $\mathrm{mm})$, medium (5 to $10 \mathrm{~mm}$ ) and large $(>10 \mathrm{~mm}$ ) follicles on each ovary were recorded daily and the total number of large follicles that disappeared on day 9 and 10 and assumed ovulated were recorded.

Statistical Analysis

A two-way Analysis of Covariance (ANCOVA) was conducted using the PROC MIX procedure of SAS (Statistical Analysis System version 9.4 for Windows; SAS Institute, Cary, NC, USA) to determine the effect of concentration of AMH (HIGH vs LOW) and FSH type (Folltropin vs FSHp) and their interaction controlling for age of water buffalo on small, medium and large follicles, as well as ovulations. Age as a covariate in the statistical model should increase the power to detect treatment effects. Changes in the populations of small, medium and large follicles over time were analyzed using repeated measures in PROC MIXED. The model to test for the main effects of treatment, day, and treatment $\mathrm{x}$ day interaction, included the fixed effects of AMH concentration category (HIGH and LOW), FSH type (Folltropin and FSHp) day $(4,5,6,7,8,9,10$, and 11) and their interactions, with day as the repeated term. The autoregressive heterogeneous covariance structure was utilized. The slope responses for day (i.e. linear vs quadratic effects) and their interaction with main effects were assessed using a polynomial contrast - using the same model, except that day was considered to be a continuous 
variable (Al- Trad et al., 2010). Results were considered significant at a confidence level of $\mathrm{P} \leq$ 0.05 and a tendency when $0.05<\mathrm{P} \leq 0.1$.

\section{Results}

Growth and development of ovarian follicles

Numbers of small, medium and large follicles varied with day of synchronization protocol (Figure 5.2). Numbers of small follicles remained constant on days 4 to 5 and decreased from day 6 through 11 ( $\mathrm{P}<0.001)$. Numbers of medium follicles increased from days 4 through 6, declined from days 7 to 9 and remained constant through days 9 to 11 (quadratic, $\mathrm{P}<0.001$ ). Numbers of large follicles remained constant on days 4 through 6 , increased from day 7 to 9 before declining (quadratic, $\mathrm{P}<0.001$ ).

Effect of the concentration of AMH and FSH preparation type on the number of small, medium and large follicles

There was an interaction of concentration of AMH x FSH preparation on the number of small follicles $(\mathrm{P}=0.02$; Figure 5.3). In animals treated with FSHp, HIGH systemic AMH was associated with more follicles. However, systemic concentration of AMH had no effect on the number of small follicles in animals treated with Folltropin V.

Water buffaloes with HIGH AMH had more small follicles ( $\mathrm{P}=0.01$; Figure 3 ) and more total $(\mathrm{P}=0.005$; Figure 5.4) follicles than animals with LOW AMH. Animals with HIGH AMH 
tended $(\mathrm{P}=0.1$; Figure 5.4) to have more large follicles than animals with LOW AMH. Concentration of AMH did not affect the number of medium follicles.

Water buffaloes treated with the FSH with a high LH content (FSHp) had more small follicles $(\mathrm{P}=0.001$; Figure 5.5) and fewer large $(\mathrm{P}<0.001$; Figure 5.5) and total follicles $(\mathrm{P}=$ 0.0005; Figure 5.5) than animals treated with FSH with a low LH content (Folltropin V). Animals treated with FSHp tended to have a greater number of medium follicles than animals treated with Folltropin V $(\mathrm{P}=0.09$; Figure 5.5).

Effect of the concentration of AMH and FSH preparation type on the number of large follicles that disappeared (ovulated)

There was significant concentration of AMH x FSH preparation interaction on the number of ovulated follicles $(\mathrm{P}=0.03$; Figure 5.6). In animals treated with Folltropin V, HIGH AMH was associated with a greater number of ovulated follicles. However systemic concentration of $\mathrm{AMH}$ had no effect on number of ovulated follicles in animals treated with FSHp. Nevertheless, systemic concentration of AMH had no effect on number of ovulated follicles in animals treated with FSHp.

Animals with HIGH AMH $(\mathrm{P}=0.05$; Figure 5.7a) and those treated with the FSH preparation with a low LH content $(\mathrm{P}<0.001$; Figure 5.7b) ovulated more follicles than animals with LOW AMH and those treated with FSH preparation with a high LH content, respectively. 


\section{Discussion}

The ovarian antral follicular reserve in water buffalo is low and highly variable among females which limits the application of superovulation and embryo transfer reproductive technologies. Identification of a reliable predictive marker of the population of small antral gonadotropin-responsive follicles is essential to improve the superovulatory response. Limited reports exist on the relationship between circulating concentration of AMH and the type of FSH preparation on follicle growth and development and on the ovulatory response in water buffaloes (Bubalus bubalis). The present study demonstrated that in water buffaloes (i) the type of FSH preparation influences the superovulatory response (ii) systemic concentration of AMH is a good indicator of the superovulatory response when the FSH preparation type with low LH is used in the superovulation treatment.

Ovulation rate was greater in buffalo females with HIGH AMH. A positive correlation between concentration of $\mathrm{AMH}$ and ovulation rate following superovulation protocols has been reported in dairy cattle (Rico et al., 2009; 2012 [0.64 and 0.43]; Souza et al., 2015 [0.65]), and in goats (Monnaiux et al., 2011 [0.87]). Therefore, AMH has been used as a predictor of the superovulatory response in these species. In addition, plasma concentrations of AMH of cows before the iniation of superovulatory treatments have been found to be characteristic of an individual female over a long-term period and predictive of numbers of ovulations and embryos produced in response to superovulation treatments (Rico et al., 2009; Monniaux et al., 2010). Whether concentration of $\mathrm{AMH}$ has a causative effect on the superovulatory response or is simply a reflection of the number of potential ovulatory follicles remains unclear. Cows with a low concentration of AMH had a low AFC and elevated circulating concentrations of FSH 
(Ireland et al., 2011). Low AFC indicates a low number of potential ovulatory follicles (Burns et al., 2005; Haughian et al., 2004; Ireland et al., 2007), which would result in a low superovulatory response. However, Baldrighi et al. (2014) suggested that buffaloes with low concentrations of $\mathrm{AMH}$ have high rates of atresia, which would result in low AFC and hence a decline in superovulatory response.

Souza et al. (2014) suggested that the reduced superovulatory response in cows with a low concentration of AMH may be due to reduced sensitivity to FSH or reduced numbers of antral follicles that can respond to exogenous FSH treatment. Scheetz et al. (2012) observed that granulosal cells from cows with high AFC (high AMH) were more sensitive to FSH than cows with low AFC (AMH). They suggested that this may be due to reduced expression of FSH receptor mRNA in granulosal cells from cows with low concentration of AMH. However, Ireland et al. (2011) suggested the elevated concentrations of FSH observed in cows with low AFC (low AMH) could down regulate follicular sensitivity to exogenous FSH stimulation.

Type of FSH preparation affected the pattern of follicular growth s and ovulation rate. In FSHp-treated animals, the number of medium follicles increased but did not transition into large ovulatory follicles. In contrast, in Folltropin-treated animals the number of small follicles increased, which then transitioned into medium and then large ovulatory follicles with progression of the estrous cycle, ultimately resulting in a greater ovulation rate in Folltropintreated cows compared to FSHp-treated animals. The positive effect of high systemic concentration of AMH on superovulatory responses was observed only in females treated with FSH preparation with low LH content. 
Folltropin is a relatively purified FSH preparation with lower LH activity due to the removal of approximately $80 \%$ of its original LH content (Amstrong et al., 1986; Wu et al., 1988). In contrast, FSHp is a relatively crude porcine pituitary extract with high LH content (Lindsell et al., 1986; Amstrong et al., 1986). In cattle, a greater superovulatory response was obtained using rbFSH without addition of exogenous LH (Looney et al., 1988; Bo et al., 2014), and ovulation rate increased with decreasing concentrations of LH in the superovulatory treatment (Chupin et al., 1984; Page et al., 1989; Willmott et al., 1990). Excess LH can cause premature luteinization or ovulation of the FSH-stimulated follicles by altering their endocrine milieu in cows (Callesen et al., 1986; 1987) and sheep (D' Aessandro et al., 2016). In addition, high LH content for prolonged periods before the LH surge disturbed the ability of follicles to ovulate without changes in recruitment and growth of follicles in cattle (Murphy et al., 1984) and sheep (Gonzalez-Bulnes et al., 2003; Dobson et al., 1997). Furthermore high LH content also initiates an increase in the number of small growing follicles (Picton et al., 1990) in an indirect way by regulating output of the growth factors. In contrast to the finding in this study and those in cattle that FSH preparations with low LH activity are preferable for superovulation (Bo et al., 2014), D'Alessandro et al., (2016) reported that the increase in total of FSH/LH ratio from 1:1 (250 IU $\mathrm{pFSH} / 250 \mathrm{IU} \mathrm{pLH})$ to $2: 1$ (250 IU $\mathrm{pFSH} / 125 \mathrm{IU} \mathrm{pLH})$ did not improve the superovulatory response in sheep. This may have been due to the massive ovarian stimulation causing a reduction in the proportion of ovulating follicles due to a decrease in their responsiveness to LH (Saumande et al., 1986).

In females treated with FSHp, high systemic concentrations of AMH were associated with a greater number of small follicles. Both FSH and LH supplementation appear to be critical for follicular development. Garza et al. (1984) suggested that in the guinea pig exogenous LH 
might induce the recruitment of small follicles by prevention of atresia. Breen et al. (2012) suggested in prepubertal gilts, that a greater amount of LH is needed to sustain small follicles and to stimulate their development. In addition, theca cells express $\mathrm{LH}$ receptors and LH stimulates the production of androgen substrates (Gougeon, 1996). Vendola et al. (1998) suggested that these androgens act as growth factors to increase the growth and number of small antral follicles. Follotropin V contains a low LH content. The LH content in Follotropin V may not support the development of small antral follicle into preovulatory follicles.

In conclusion, a positive correlation between the concentration of $\mathrm{AMH}$ and the superovulatory response was observed in water buffaloes. Because a high repeatability in the intra-animal systemic concentration of $\mathrm{AMH}$ exists, use of $\mathrm{AMH}$ concentration determined from a single blood sample may be used to predict females that will show a high and repeatable response to superovulation treatments. The use of FSH preparations with lower LH content could be used to improve the low superovulatory response in water buffaloes. 


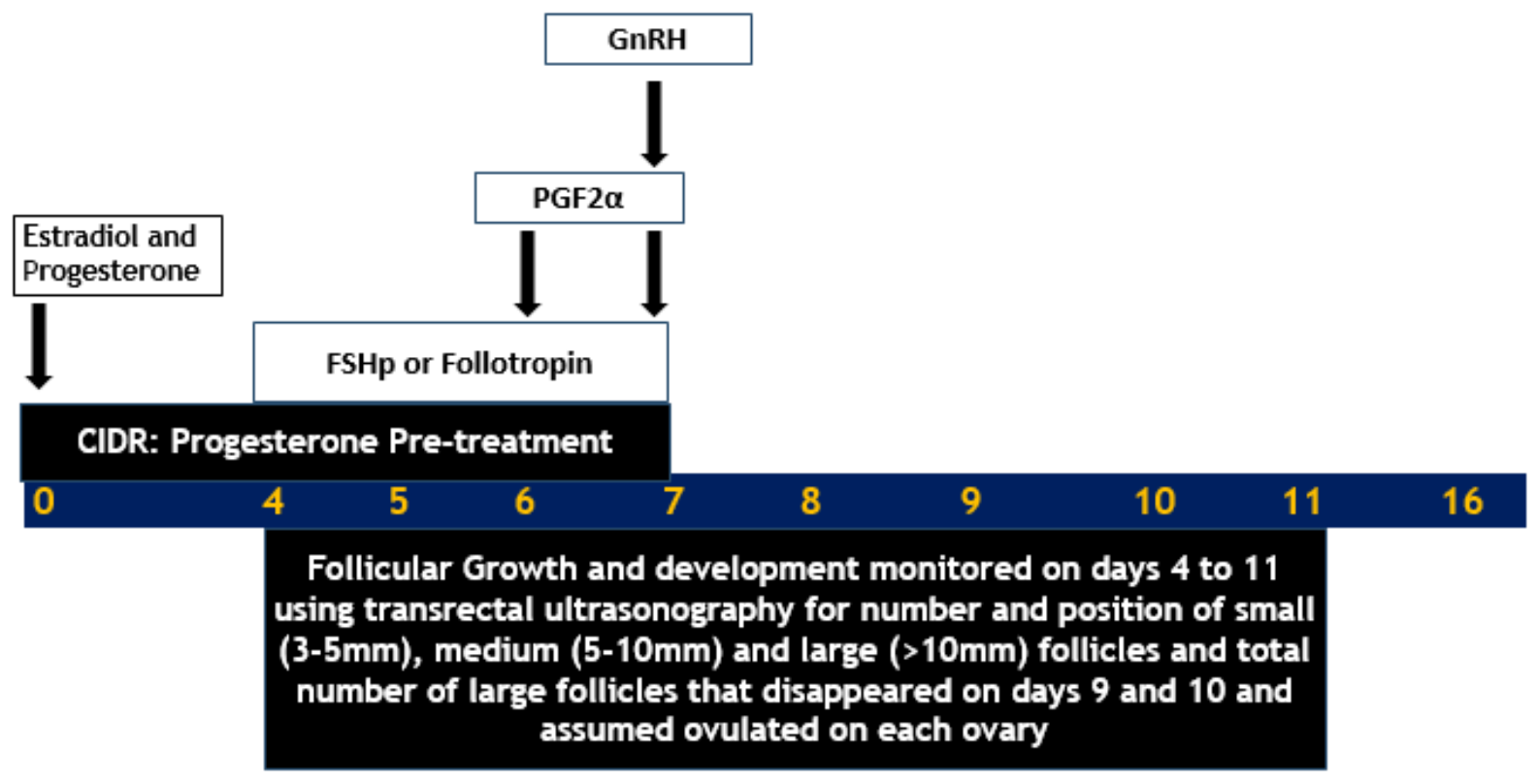

Figure 5.1. Experimental Plan and Timeline. 


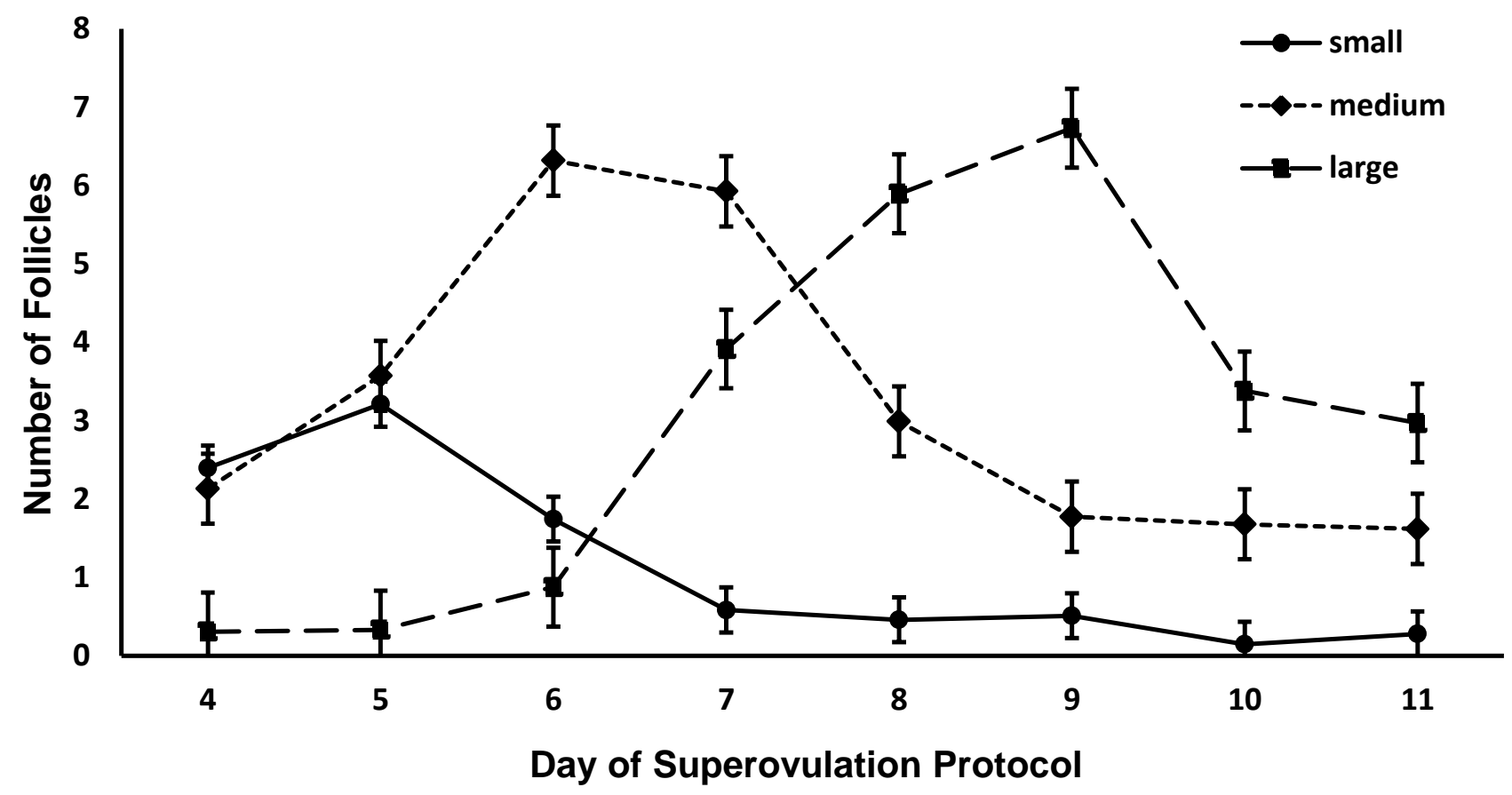

Figure 5.2. Growth and development of small $(3-5 \mathrm{~mm})$, medium $(5-10 \mathrm{~mm})$ and large (> 10 $\mathrm{mm}$ ) ovarian follicles of water buffaloes (Bubalus bubalis, $\mathrm{n}=31$ ) treated to induce superovulation during the pre-ovulatory period. Values are least square means \pm SEM. Day effect for small, medium and large follicles $\mathrm{P}<0.001$. 


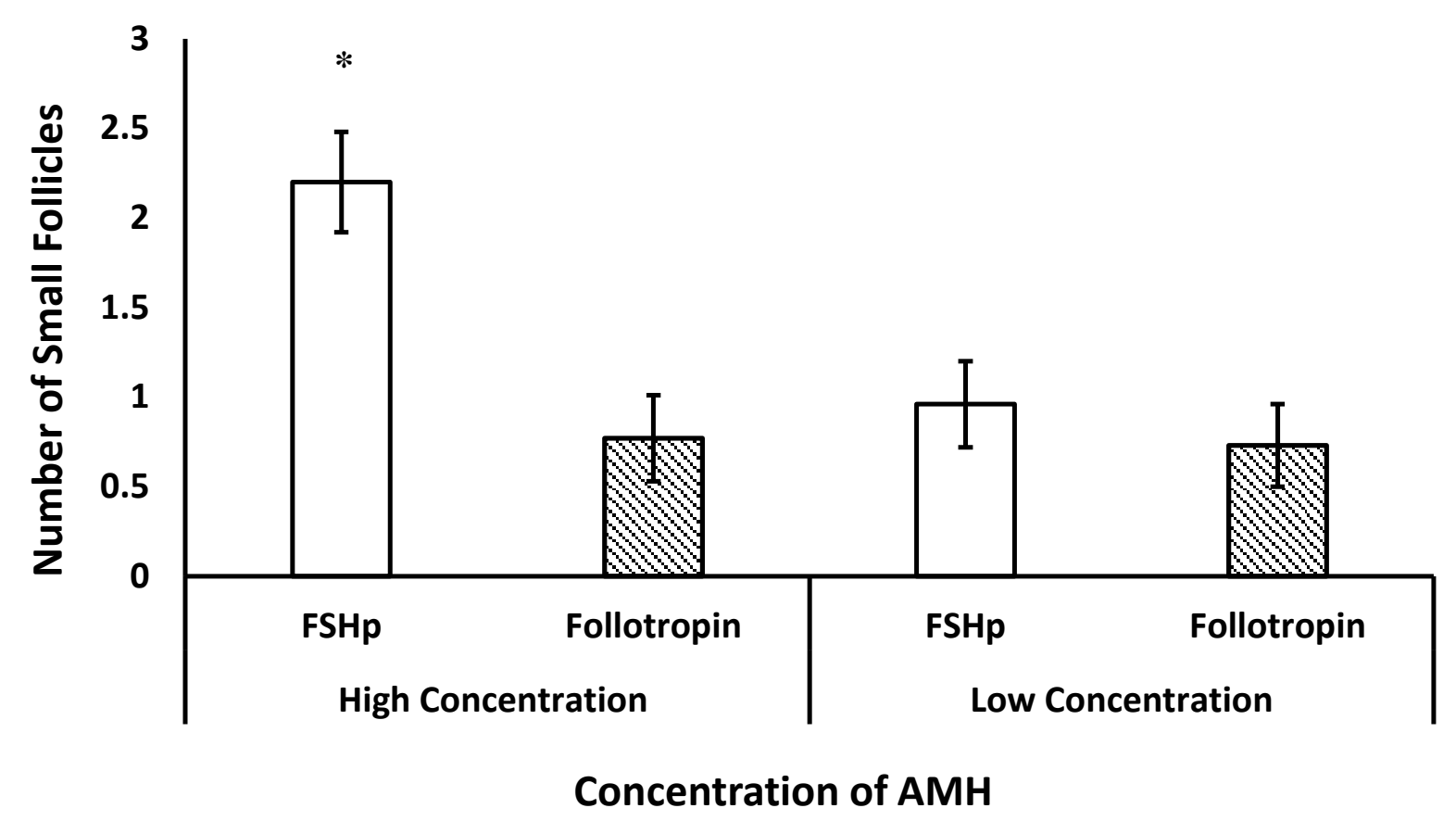

Figure 5.3. Interaction of concentration of AMH (High and Low) and type of FSH preparation type (FSHp high LH content vs Follotropin low LH content) on the number of small (3-5 mm) follicles during the pre-ovulatory period in water buffaloes (Bubalus bubalis, $\mathrm{n}=31$ ) treated to induce superovulation Values are least squares means $\pm \mathrm{SEM}$. $* \mathrm{P}<0.05$, compared with cows treated with Follotropin. 


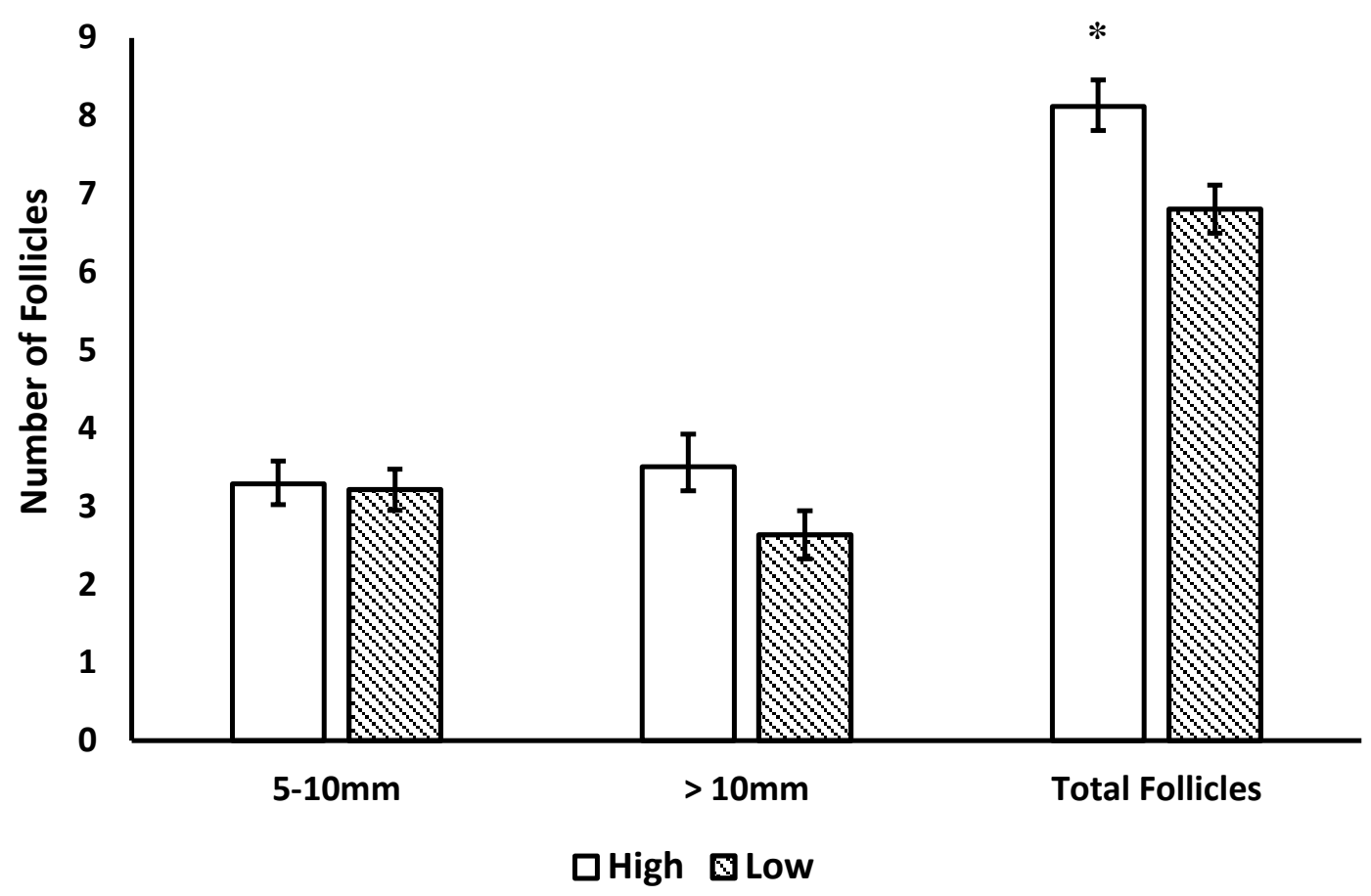

Figure 5.4. Effect of concentrations of AMH (Low vs. High) on numbers of medium (5-10 mm), large $(>10 \mathrm{~mm})$ and total follicles of water buffaloes (Bubalus bubalis, $\mathrm{n}=31$ ) during the preovulatory period treated to induce superovulation. Values are least square means \pm SEM. *P < 0.05 , compared with cows with low concentration of AMH. 


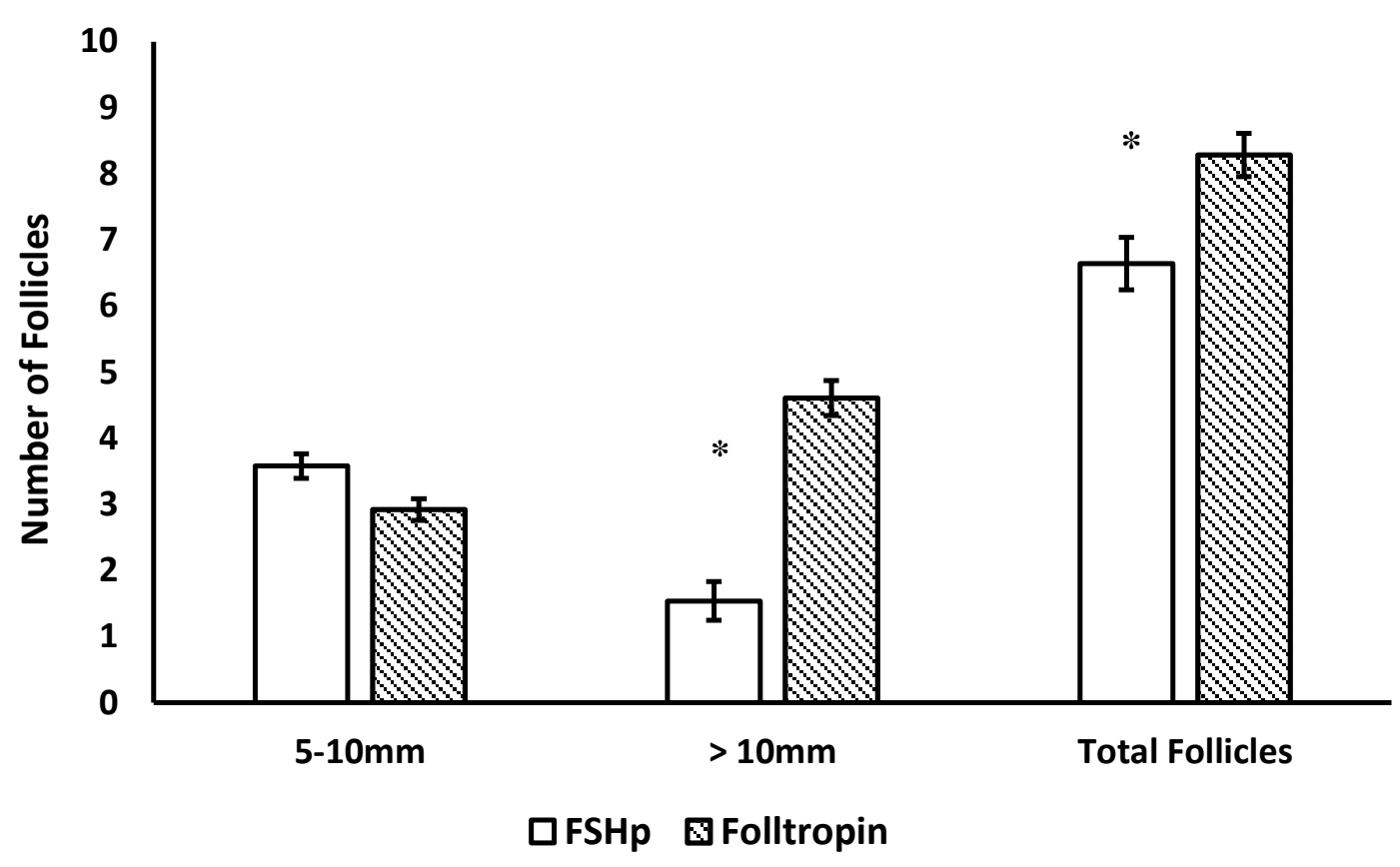

Figure 5.5. Effect of type of FSH preparation (FSHp, high LH content vs Follotropin, low LH content) on numbers of medium $(5-10 \mathrm{~mm})$, large $(>10 \mathrm{~mm})$ and total follicles during the preovulatory period in water buffaloes (Bubalus bubalis, $\mathrm{n}=31$ ) given treated to induce superovulation. Values are least squares means \pm SEM. Values are least squares means \pm SEM. $* \mathrm{P}<0.05$, compared with cows treated with Follotropin. 


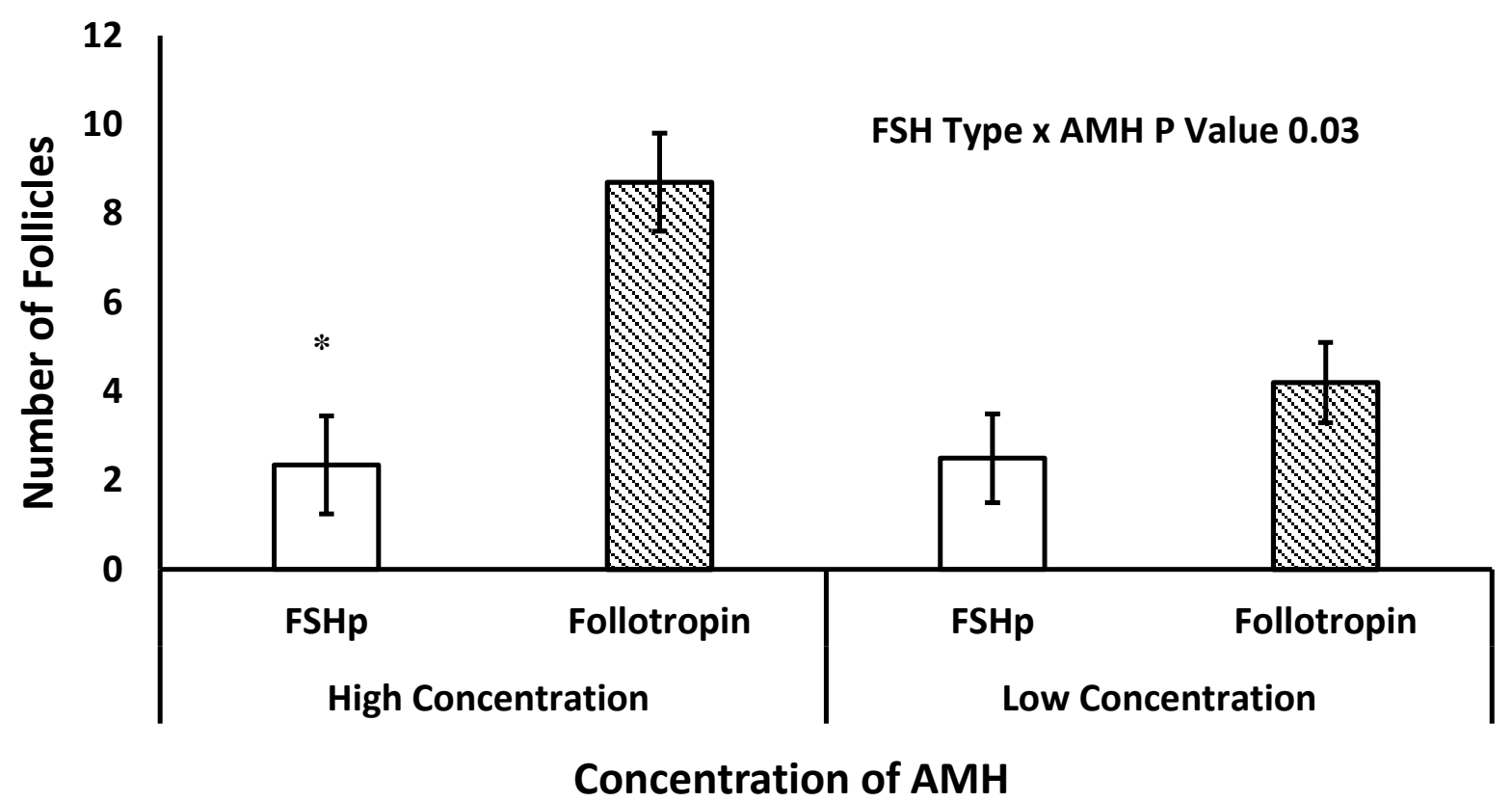

Figure 5.6. Effect of concentration of AMH (Low and High) and type of FSH preparation type (FSHp, high LH content and Follotropin, low LH content) on the number of large (>10 mm) follicles that disappeared in water buffaloes $(n=31)$ treated to induce superovulation. Values are least squares means $\pm \mathrm{SEM}$. $* \mathrm{P}<0.05$, compared with cows treated with Follotropin. 
(a) Concentration of $\mathrm{AMH}$

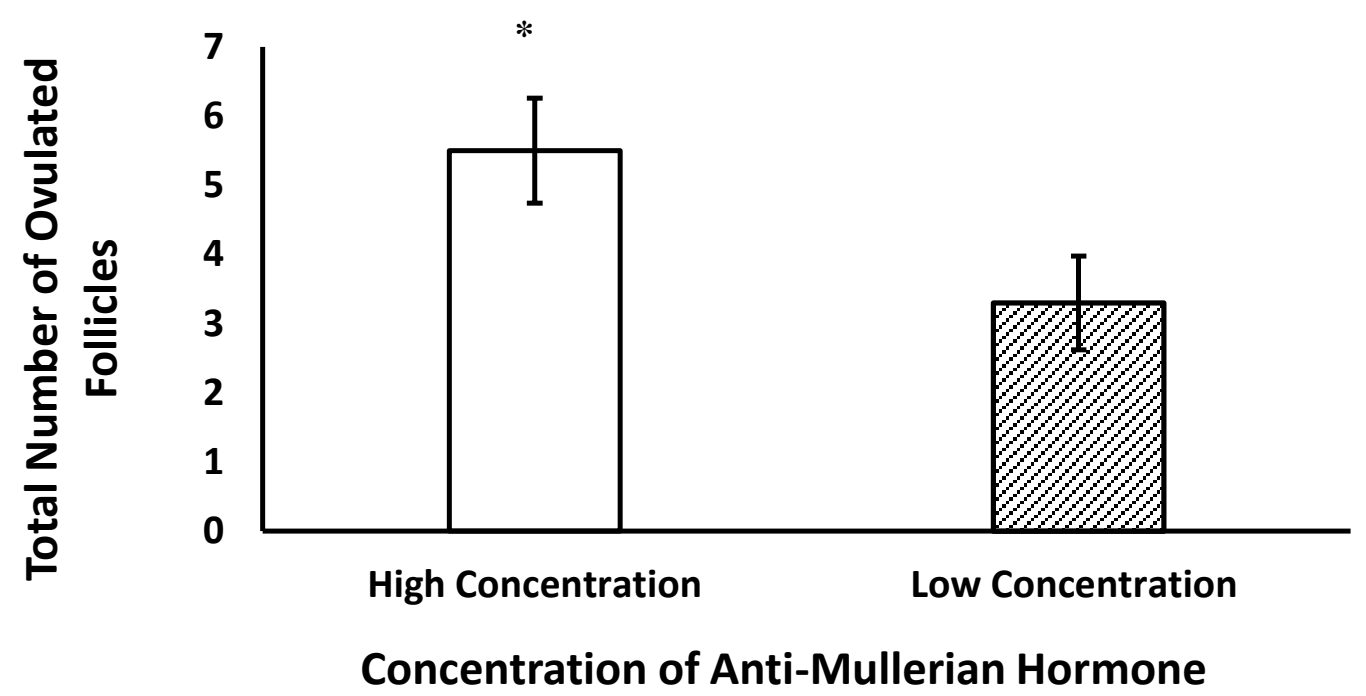

(b) FSH Preparation Type

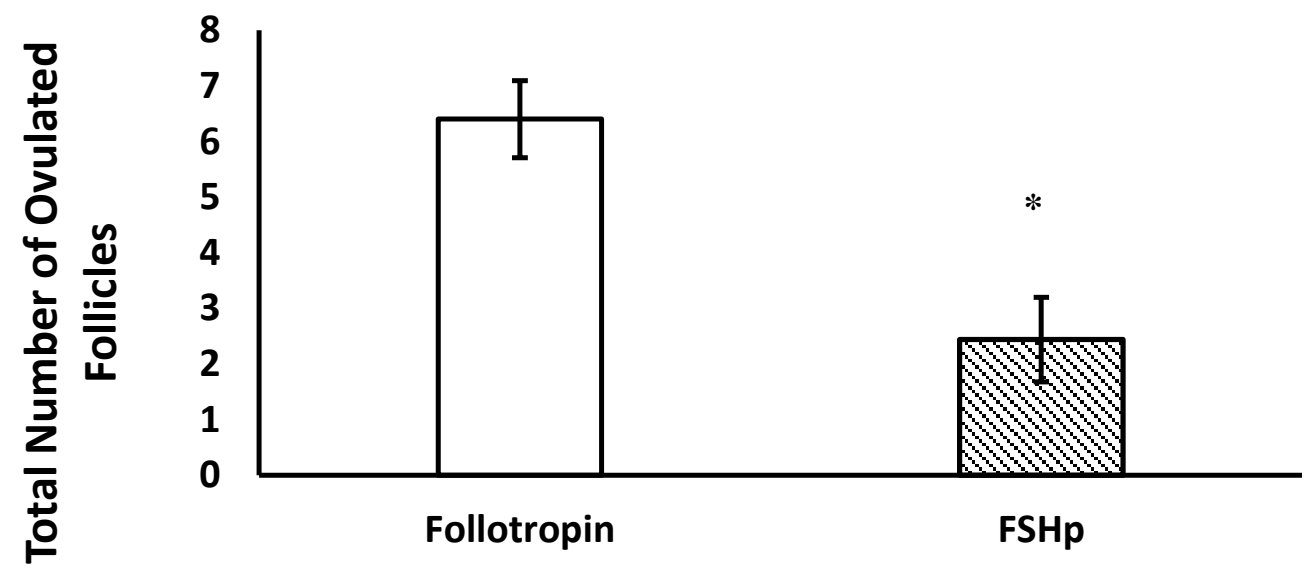

FSH Preparation Type

Figure 5.7. Effect of (a) concentration of AMH (Low vs. High concentrations) (b) FSH preparation type (FSHp high LH content vs. Follotropin low LH content) on the number of large $(>10 \mathrm{~mm})$ follicles that disappeared in water buffaloes $(\mathrm{n}=31)$ treated to induce superovulation. Values are least square means \pm SEM). $* \mathrm{P}<0.05$, compared with cows with low AMH concentration and treated with Follotropin, respectively. 


\section{CHAPTER 6}

\section{SUMMARY AND GENERAL CONCLUSIONS}

With the experiments presented in this dissertation, we have evaluated the relationship between concentration of anti-mullerian hormone (AMH) and (1) age and breed in replacement ewes (2) age and follicular growth and development in water buffaloes (3) type of FSH preparation, follicular growth and development and superovulatory response in water buffaloes.

In study 1 , the objectives were to evaluate the concentration of $\mathrm{AMH}$ in replacement females of different breeds and ages and to determine if the relationship between the concentration of AMH and fertility varies with breed. It was observed that Katahdin replacement females had a higher concentration of AMH than Dorset/Texel (DT) and Sufflolk females. In addition, as age increases AMH decreased for Dorset females only. Katahdin females with HIGH AMH had a higher conception rate and lambing to the first service AMH did not affect conception rate and lambing to service of Dorset replacement females. Furthermore, Katahdin replacement females that conceived and lambed to the first service had a higher concentration of AMH. AMH did not differ

among Dorset females. From this study, we concluded that a single measurement of systemic AMH may be a useful tool to select replacement females with a high reproductive performance. In addition, AMH varies among breed in replacement ewes. Therefore, it is important to consider breed when developing threshold values to delineate the potential for high and low reproductive outcome when interpreting AMH data.

In study 2, the objectives were to define the concentration of $\mathrm{AMH}$ in water buffaloes and its relationship to age, pattern of growth and development of follicles and 
ovulation in water buffaloes. It was observed that the within cow repeatability of AMH was 0.97 and $\mathrm{AMH}$ increased until 10 years of age and then decreased. In addition, females with HIGH AMH had more large follicles and follicles with a greater maximum diameter than females with LOW AMH. From this study we concluded that since a high repeatability in the intra-animal systemic concentration of AMH was observed and females with HIGH AMH had more large follicles, a single blood sample can be used to make reproductive decisions in reference to a specific animal.

In study 3 , the objectives were to determine the relationship between AMH and type of follicle stimulating hormone (FSH) preparation on follicular growth and ovulatory response in water buffaloes. It was observed that females with HIGH AMH had more small follicles. Females treated with FSH preparation with a high LH content had more small follicles and fewer large and lower total number of follicles. In females treated with FSHp, high systemic concentration of AMH was associated with more small follicles. Females with HIGH AMH and those treated with FSH preparation with a low LH content had more ovulated follicles. In animals treated with Follotropin V, high systemic AMH was associated with more ovulated follicles. From this study we concluded that the use of the concentration of AMH determined from a single blood sample to select high responders and the use of FSH preparations with lower LH content can be used to improve the low superovulatory response in water buffaloes.

These experiments provide useful information regarding the use of $\mathrm{AMH}$ to identify animals with a high reproductive potential in replacement females and water buffaloes. In addition, these studies demonstrate the importance of separately considering animals of different genetic backgrounds when analyzing and interpreting AMH data for 
replacement females. However, further studies are needed to investigate further the relationship between AMH and fertility in replacement females. For example, the use of AMH to predict field fertility is still controversial and further studies using large numbers of animals are needed to make definite conclusions. In addition, the results of these studies may allow us to propose AMH a reliable marker of ovarian activity and as a predictor of ovarian response to superovulation treatments. 


\section{REFERENCES}

Aerts, J.M., Bols, P.E. 2010. Ovarian follicular dynamics:a review with emphasis on the bovine species. Part 1: Folliculogenesis and pre-antral follicle development Reproduction in Domestic Animals 45:171-179.

Alexandratos, N., Bruinsma, J., Bödeker, G., Schmidhuber, J., Broca, S., Shetty, P., Ottaviani, M.G. 2012. World agriculture towards 2030/2050: ESA working paper No. 12-03, Agricultural Development Economics Division, Food and Agriculture Organization of the United Nations.

Almeida,J., Ball, B.A., Conley, AJ., Place, N.J., Liu, I.K., Scholtz, E.L., Mathewson, L., Stanley, S.D., Moeller, B.C. 2011. Biological and clinical significance of anti-Mullerian hormone determination in blood serum of the mare. Theriogenology 76:1393-1403.

Ali, A., A.K. Abdel-Razek, S. Abdel-Ghaffar,P.S. Glatzel. 2003. Ovarian Follicular Dynamics in Buffalo Cows (Bubalus bubalis). Reproduction in Domestic Animals 38:214-218.

Al-Trad, B., Wittek, T., Penner, G.B., Reisberg, K., Gabel, G., Furll, M., Aschenbach, J.R. 2010. Expression and activity of key hepatic gluconeogenesis enzymes in response to increasing intravenous infusions of glucose in dairy cows. Journal of Animal Science 88:2998-3008.

Amstrong, M.A., Opavsky, M.A. 1986. Biological characterization of a pituitary FSH preparation with reduced LH activity. Theriogenology 25:135.

Andersen, C.Y., Schmidt, K.T., Kristensen, S.G., Rosendahl, M., Byskov, A.G., Ernst, E. 2010. Concentrations of $\mathrm{AMH}$ and inhibin-B in relation to follicular diameter in normal human small antral follicles. Human Reproduction 25:1282-1287.

Avdi, M. Chemineau, P. Draincourt, M.A. 1997. Alterations in follicular maturation associated with within-breed variation in ovulation rate in Chios sheep. Animal Reproduction Science 46:223-235.

Baarends, W.M., Uilenbroek, J.T., Kramer, P., Hoogerbrugge, J.W., van Leeuwen, E.C., Themmen, A.P., Grootegoed, J.A. 1995. Anti-mullerian hormone and anti-mullerian hormone type ii receptor messenger ribonucleic acid expression in rat ovaries during postnatal development, the estrous cycle, and gonadotropin follicle growth. Endocrinology 136:4951-4962.

Baerwald, A.R., Adams, G.P., Pierson, R.A. 2012. Ovarian antral folliculogenesis during the human menstrual cycle: a review. Human Reproduction Update 18:73-91. 
Baldrighi, J.M., Sá Filho, M.F., Batista, E.O.S., Lopes, R.N.V.R., Visintin, J.A., Baruselli, P.S., Assumpção, M.E.O.A. 2014. Anti-Mullerian Hormone Concentration and Antral Ovarian Follicle Population in Murrah Heifers Compared to Holstein and Gyr Kept Under the Same Management. Reproduction in Domestic Animals 49:1015-1020.

Bao, B., Garverick, H.A. 1998. Expression of steroidogenic enzyme and gonadotropin receptor genes in bovine follicles during ovarian follicular waves: a review. Journal of Animal Science 76:1903-1921.

Baruselli, P.S., 1994. Basic requirements for artificial insemination and embryo transfer in buffaloes. Buffalo Journal 2:53-60.

Baruselli, P.S., Mucciolo, R.G., Visintin, J.A., Viana, W.G., Arruda, R.P., Madureira, E.H., Oliveira, C.A., Molero-Filho, J.R. 1997. Ovarian follicular dynamics during the estrous cycle in buffalo (Bubalus bubalis). Theriogenology 47:1531-1547.

Batista E.O.S., Macedo, G.G., Sala, R.V., Ortolan, M., Sá Filho, M.F., Del Valle, T.A., Jesus, E.F., Lopes, R., Rennó, F.P., Baruselli, P.S. 2014. Plasma anti-mullerian hormone as a predictor of ovarian antral follicular population in Bos indicus (Nelore) and Bos taurus (Holstein) heifers. Reproduction in Domestic Animals 49:448-452.

Batista, E.O.S., Guerreiro, B.M., Freitas, B.G., Silva, J.C.B., Vieira, L.M., Ferreira, R.M., Rezende, R.G., basso, A.C., Lopes, R.N.V.R., Renno, F.P., Souza, A.H., Barsuselli, P.S. 2016. Plasma antimullerian hormone as a predictive endocrine marker to select Bos taurus and Bos indicus (Nelore) calves for in vitro embryo production. Domestic Animal Endocrinology 54:1-9.

Beau, C., Raud, M., Joulin, V., Jegou, B., Guerrier D. 2000. GATA-1 is a potential repressor of anti-Mullerian hormone expression during the establishment of puberty in the mouse. Molecular Reproductive Development 56:124-138.

Beg M.A., Ginther, O.J. 2006. Follicle selection in cattle and horses: role of intrafollicular factors. Reproduction 132:365-377.

Bentzen J.G., Forman, J.L., Johannsen, T.H., Pinborg, A., Larsen, E.C., Andersen, A.N. 2013. Ovarian antral follicle subclasses and anti-Mullerian hormone during normal reproductive aging. Journal of Clinical Endocrinology and Metabolism 98:1602-11.

Black, J.L., Erickson, B.H. 1968. Oogenesis and ovarian development in the prenatal pig. Anatomical Record 161:45-55.

Bo, G.A., Barsuelli, P.S., Martinez, M.F. 2003. Pattern and manipulation of follicular development in Bos indicus cattle. Animal Reproduction Science 78:307-326. 
Bodensteiner K.J., Wiltbank, M.C., Bergfelt, D.R., Ginther, O.J. 1996. Alterations in follicular estradiol and gonadotropin receptors during development of bovine antral follicles. Theriology 45:499-512.

Breuel, K.F., Baker, R.D., Butcher, R.L., Townsend, E.C., Inskeep, E.K., Dailey, R.A., Lerner, S.P. 1991. Effects of breed, age of donor and dosage of follicle stimulating hormone on the superovulatory response of beef cows. Theriogenology 36:241-255.

Brodin,T., Bergh, T., Berglund, L., Hadziosmanovic, N., Holte, J. 2009. High basal FSH levels in combination with low basal FSH levels are associated with high success rates at assisted reproduction. Human Reproduction 24:2755-2799.

Breen,S.M., Knox, R.V. 2012. The impact of dose of FSH (Folltropin) containing LH (Lutropin) on follicular development development, estrus and ovulation responses in prepubertal gilts. Animal Reproduction Science 132:193-200.

Brown, J.B. 1978. Pituitary control of ovarian function: concepts derived from gonadotropin therapy. Australian and New Zealand Journal of Obstetrics and Gynaecology 18:46-54.

Burger, H.G., Dudley, E.C., Robertson, D.M., Dennerstein, L. 2002. Hormonal changes in menopause transition. Recent Progress in Hormone Research 57:257-275.

Burke, C.R., Day, M.L., Bunt, C.R., Macmillan, K.L. 2000. Use of a small dose of estradiol benzoate during diestrus to synchronize development of the ovulatory follicle in cattle. Journal of Animal Science 78:145-151.

Burns, D.S., Jimenez-Krassel, F., Ireland, J.H.L., Knight, P.G., Ireland, J.J. 2005. Numbers of antral follicles during follicular waves in cattle: Evidence for high variation among animals, very high repeatability in individuals, and an inverse association with serum follicle-stimulating hormone concentrations. Biology of Reproduction 73:54-62.

Callesen, H., Greve, T., Hyttel, P. 1986. Preovulatory endocrinology and oocyte maturation in superovulated cattle. Theriogenology 25:71-86.

Callesen, H., Greve, T., Hyttel, P. 1987. Premature ovulations in superovulated cattle. Theriogenology 28:155-166.

Canadian International Development Agency (CIDA). 2013. CIDA's Food Security Strategy (http://www.acfi-cida.gc.ca/acdi-cida/ - Accessed 9th August 2016)

Caroppo, E., Matteo, M., Schonauer, L.M., Vizziello, G., Pasquadibisceglie, A., Vitti, A., D'Amato, G. 2006. Basal FSH concentration as a predictor of IVF outcome in older women undergoing stimulation with $\mathrm{GnRH}$ antagonist. Reproductive Bio Medicine Online 13:815-820. 
Carvalho, N.A.T., Baruselli, P.S., Zicarelli, L., Madureira, E.H., Visintin, J.A., Occhio, M.D. 2002. Control of ovulation with a GnRH agonist after superstimulation of follicular growth in buffalo: fertilization and embryo recovery. Theriogenology 58:1641-1650.

Cate R.L., Mattaliano, R.I., Hession, C., Tizard, R., Farber, N.M., Cheung, A., Ninfa, E.G., Frey, A.Z., Gash, D.I., Chow, E.P., Fisher, R.A., Bertonis, J.M., Torres, G., Wallner, B.P., Ramachandran, K.L., Ragin, R.C., Manganaro, T.F., Maclaughlin, D.T., Donahoe, P.K. 1986. Isolation of the bovine and human genes for Mullierian-Inhibiting substance and expression of the human gene in animal cells. Cell 45:685-698.

Chang, H.M., Klausen, C., Leung, P.C. 2013. Antimüllerian hormone inhibits folliclestimulating hormone-induced adenylyl cyclase activation, aromatase expression, and estradiol production in human granulosa-lutein cells. Fertility and Sterility 100:585-592.

Chebel, R.C., Braga, F.A., Dalton, J.C. 2007. Factors affecting reproductive performance of Holstein heifers. Animal Reproduction Science 101:208-224.

Choudhary, K.K., Kavya, K.M., Jerome, A., Sharma, R.K. 2016. Advances in reproductive biotechnologies Veterinary World 9:388-395.

Chun, S. 2014. Serum luteinizing hormone level and luteinizing hormone/follicle-stimulating hormone ratio but not serum anti-Mullerian hormone level is related to ovarian volume in Korean women with polycystic ovary syndrome. Clinical and Experimental Reproductive Medicine 41:86-91.

Chun, S.Y., Eisenhauer, K.M., Minami, S., Billig, H., Perlas, E., Hsueh, A.J. 1996: Hormonal regulation of apoptosis in early antral follicles: follicle-stimulating hormone as a major survival factor. Endocrinology 137:1447-1456.

Chupin, D., Combarnous, Y., Procureur, R. 1984. Antagonistic effect of LH in commercially available gonadotropins. Theriogenology 25:167.

Clarke, T.R., Hoshiya, Y., Yi, S.E., Liu, X., Lyons, K.M., Donahoe, P.K. 2001. Mullerian inhibiting substance signaling uses bone morphogenetic protein (BMP) like pathway mediated by ALK2 and induces SMAD6 expression. Molecular Endocrinology 15:946959.

Cook, C.L, Siow, Y., Taylor, S., Fallat, M.E. 2000. Serum mullerian-inhibiting substance levels during normal menstrual cycles. Fertility and Sterility 73:859-861.

Crowe, M.A, Kelly, P., Driancourt, M.A., Boland, M.P., Roche, J.F. 2001. Effects of folliclestimulating hormone with and without luteinizing hormone on serum hormone concentrations, follicle growth, and intrafollicular estradiol and aromatase activity in gonadotropin-releasing hormone immunized heifers. Biology of Reproduction 64:368374. 
Cushman, R.A, Wood, J.R., Slattery, R.G., Clopton, D.T. 2010. Reproductive aging influences ovarian function in beef cows. Nebraska Beef Cattle Reports. Paper 558.

Cushman, R.A., Allan, M.F., Kuehn, L.A., Snelling, W.M., Cupp, A.S., Freetly, H.C. 2009. Evaluation of antral follicle count and ovarian morphology in crossbred beef cows: Investigation of influence of stage of the estrous cycle, age, and birth weight. Journal of Animal Science 87:1971-1980.

D’Alessandro, A.G., Martemucci, G. 2016. Superovulatory response to gonadotrophin FSH/LH treatment and effect of progestin supplement to recipients on survival of transferred vitrified embryos in goats. Theriogenology 85:296-301.

Danell, B. 1987. Oestrus behaviour, ovarian morphology and cyclic variations in follicular system and endocrine pattern in water buffalo heifers. PhD thesis. Uppsala, Sweden: Sveriges Lantbruksuniversiter.

Da Silva-Buttkus, P., Jayasooriya, G.S., Mora, J.M., Mobberley, M., Ryder, T.A., Baithun, M., Stark, J., Frank, S., Hardy, K. 2008. Effect of cell shape and packing density on granulosa cell proliferation and formation of multiple layers during early follicle development in the ovary. Journal of Cell Science 121:3890-3900.

De Renesis, F., Peters, A.R. 1999. The control of follicular dynamics by PGF2alpha, GnRH and hCG and oestrus synchronization in cattle. Reproduction in Domestic Animals 34:49-59.

De Vet, A., LAven, J.S., de Jong, F.H., Themmen, A.P.N., Fauser, B.C. 2002. Antimullerian hormone serum levels: a putative marker for ovarian aging. Fertility and Sterility 77:357362.

Di Clemente, N., Goxe, B., Remy, J.J., Cate, R.L., Josso, N., Vigier, B., Salesse, R. 1994. Inhibitory effect of AMH upon aromatase activity and LH receptors of granulosa cells of rat and porcine immature ovaries. Endocrine 2:553-558.

Dobson, H., Campbell, B.K., Gordon, B.M., Scaramuzzi, R.J. 1997. Endocrine activity of induced persistent follicles in sheep. Biology of Reproduction 56:208-213.

Donaldson,L.E. 1984. The effect of age of the donor cow on embryo production Theriogenology 22:97-99.

Draincourt, M.A. 2001. Regulation of ovarian follicular dynamics in farm animals. Implications for manipulation of reproduction. Theriogenology 55:1221-1239.

Draincourt, M.A., Gauld, I.K., Terqui, M., Webb, R. 1986. Variations in patterns of follicle development in prolific breeds of sheep. Journal of Reproduction and Fertlity 78:565575 . 
Dresser, D., Hacker, A., Lovell-Badge, R., Guerrier, D. 1995. The genes for a spliceosome protein (SAP62) and the anti-Mullerian hormone are contiguous. Human Molecular Genetics 4:1613-1618.

Drost, M. (2007). Advanced reproductive technology in the water buffalo. Theriogenology, $68: 450-453$.

Durlinger, A.L., Gruijters, M.J., Kramer, P., Karels, B., Kumar, T.R., Matzuk, M.M., Rose, U.M., de Jong, F.H., Uilenbroek, J.T., Grootegoed, J.A., Themmen, A.P. 2001. AntiMullerian hormone attenuates the effects of FSH on follicle development in the mouse ovary. Endocrinology 142:4891-4899.

Durlinger, A.L., Kramer, P., Karels, B., de Jong, F.H., Uilenbroek, J.T., Grootegoed, J.A., Themmen, A.P. 1999. Contol of primordial follicle recruitment by Antimullerian hormone in the mouse ovary. Endocrinology 140:5789-5796.

Durlinger, A.L., Visser, J.A., Themmen, A.P. 2002a. Regulation of ovarian function: the role of antimullerian hormone. Reproduction 124:601-609.

Durlinger, A.L.L., Gruijters, M.J.G., Kramer, P., Nachtigal, B.K., Uilenbroek, J.T., Grootegoed, J.A., Themmen, A.P.N. 2002b. Anti-müllerian hormone inhibits initiation of primordial follicle growth in the mouse ovary. Endocrinology 143:1076-1084.

Edwards, S.J., B. Smaill, A.R. O'Connell, P.D. Johnstone, D.R. Stevens, L.D. Quirke, P.A. Farquhar, J.L. Juengel. 2016. Reduced ovulation rate, failure to be mated and fertilization failure/embryo loss are the underlying causes of poor reproductive performance in juvenile ewes. Animal Reproduction Science 167:125-132.

Eppig, J.J. 2001. Oocyte control of ovarian follicular development and function in mammals. Reproduction 122:829-838.

Erickson, B.H. 1966. Development and senescence of the postnatal bovine ovary. Journal of Animal Science 25:800-805.

Evans, A.C.O. 2003. Characteristics of ovarian follicle development in domestic animals. Reproduction in Domestic Animals 38:240-246.

Evers, J.L., Slaats, P., Land, J.A., Dumoulin, J.C., Dunselman, G.A. 1998. Elevated levels of basal estradiol 17 beta predict poor response in patients with normal basal levels of follicle-stimulating hormone undergoing in vitro fertilization. Fertility and Sterility 69:1010-1014.

Fanchin, R., Schonauer, L.M., Righini, C., Guibourdenche, J., Frydman, R., Taieb, J. 2003. Serum anti-Mullerian hormone is more strongly related to ovarian follicular status than serum inhibin B, estradiol, FSH and LH on day 3. Human Reproduction 18:323-327. 
Fauser, B.C., Van Heusden, A.M. 1997. Manipulation of human ovarian function: physiological concepts and clinical consequences. Endocrine Reviews 18:71-106.

Feranil, J.B., Isobe, N., Nakao, T. 2004. Cell proliferation in the atretic follicles of buffaloand cattle ovary. Reproduction in Domestic Animals 39:405-409.

Filicori M., Cognigni, G.E., Tabarelli, C., Pocognoli, P., Taraborrell, S., Spettoli, D., Ciampaglia, W. 2002. Stimulation and growth of antral ovarian follicles by selective LH activity administration in women. Journal of Clinical Endocrinology and Metabolism $87: 1156-1161$.

Filion F., Bouchard, N., Goff, A.K., Lussier, J.G., Sirois, J. 2001. Molecular cloning and induction of bovine prostaglandin E synthase by gonadotropins in ovarian follicles prior to ovulation in vivo. Journal of Biological Chemistry 276:34323-34330.

Fortune, J.E. 2004. Ovarian follicular growth and development in mammals. Biology of Reproduction 50:225-232.

Fortune, J.E., M.Y. Yang, W. Muruvi. 2010. In vitro and in vivo regulation of follicular formation and activation in cattle. Reproduction, Fertility and Development 23:15-22.

Fosgate, G.T., Diptee, M.D., Ramnanan, A., Adesiyun, A.A. 2011. Brucellosis in domestic water buffalo (Bubalus bubalis) of Trinidad and Tobago with comparative epidemiology to cattle. Tropical Animal Health and Production 43:479-1486.

Fraisse, T., Ibecheole,V., Streuli, I. bischof, P. de Ziedler,D. 2008. Undetectable serum antimullerian hormone levels and occurrence of ongoing pregnancy. Fertility Sterility 89:723.e9-723.e11.

Gabriel, B.A., Mapletoft, R.J. 2014. Historical perspectives and recent research on superovulation in cattle. Theriogenology 81:38-48.

Gamarra, G., Ponsart, C., Lacaze, S., Le Guienne, B., Humblot, P., Deloche, M.C., Monniaux, D., Ponter, A.A. 2014. Dietary propylene glycol and in vitro embryo production after ovum pick-up in heifers with different anti-Müllerian hormone profiles. Reproduction Fertility and Development 27:1249-1261.

Garcia-Salas, A., Cortez-Romero, C., Salazar-Ortiz, J., Arroyo-Ledezma, J., Vaquera-Huerta, V.M., Gallegos-Sanchez, J. 2017. Administration of exogenous hormones in ovulatory and embryonic response in pelibuey sheep. Reproduction in Domestic Animals:1-6.

Garza,F., Shaban, M.A., Terranova, P.F. 1984. Luteinizing hormone increases the number of ova shed in the cyclic hamster and guinea-pig. Journal of Endocrinology 101:289-298.

Garcia, J.F., R.V. Alonso, Y.T. Utsunomiya, A.S. Carmo. 2013. Genomic selection and assisted reproduction technologies to foster cattle breeding. Animal Reproduction 10:297-301. 
Gasparrini B., G. Neglia, R. Di Palo, D. Vecchio, G. Albero, L. Esposito. 2014. Influence of oocyte donor on in vitro embryo production in buffalo. Animal Reproduction Science 144:95-101.

Gasparrini, B. 2002. In vitro embryo production in buffalo species: state of the art. Theriogenology 57:237-56.

Gimenes, L.U., Sa Filho, M.F., Carvalho, N.A.T., Torres Junior, J.R.S., Souza, A.H., Madureira, E.H., Trinca, L.A., Sartorelli, E.S., Barros, C.M., Carvalho, J.B.P. Mapletoft, R.J., Baruselli, P.S. 2009. Follicular dynamics of Bos indicus, Bos Taurus and Bubalus bubalis heifers treated with norgestomet ear implant associated or nt to injectable progesterone. Animal Reproduction 6:256.

Gimenes,L.U., N.A. Carvalho, M.F. Sa Filho, F.S. Vannucci, J.R. Torres-Junior, H. Ayres, R.M. Ferreira, L.A. Trinca, E.S. Sartorelli, C.M. Barros, M.P. Beltran, G.P. Noqueira, R.J. Mapletoft, P.S. Baruselli. 2011. Ultrasonographic and endocrine aspects of follicle deviation, and acquisition of ovulatory capacity in buffalo (Bubalus bubalis) heifers. Animal Reproduction Science 123:175-179.

Ginther O.J., Beg, M.A., Bergfelt, D.R., Donadeu, F.X. Kot, K. 2001. Follicle selection in monovular species. Biology of Reproduction 65:638-647.

Ginther, O.J., Beg, M.A., Donadeu, F.X., Bergfelt, D.R. 2003. Mechanism of follicle deviation in monovular farm species. Animal Reproduction Science 78:239-257.

Ginther, O.J., Bergfelt, D.R., Kulick, L.J., Kot, K. 2000 Selection of the dominant follicle in cattle: role of estradiol. Biology of Reproduction 63:383-389.

Ginther, O.J., Kastelic, J.P., Knopf, L. 1989. Composition and characteristics of follicular waves during the bovine estrous cycle. Animal Reproduction Science 20:187-200.

Giuili, G., Shen, W.H., Ingraham, H.A. 1997. The nuclear receptor SF-1 mediates sexually dimorphic expression of mullerian-inhibiting Substance, in vivo. Development 124:17991807.

Glister, C., Tannetta, D.S., Groome, N.P., Knight, P.G. 2001. Interactions between folliclestimulating hormone and growth factors in modulating secretion of steroids and inhibinrelated peptides by nonluteinized bovine granulosa cells. Biology of Reproduction 65:1020-1028.

Gonzalez-Bulnes, A., Carlos, J.H., Campbell, B., Barid, D. 2003. Effect of aging on hormone secretion and follicular dynamics in sheep with and without the Booroola gene. Endocrinology 143:2858-2864. 
Gouedard, L., Chen, Y.G., Thevenet, L., Racine, C., Boric, S., Lamarre, I., Josso, N., Massague, J., di Clemente, N. 2000. Engagement of bone morphogenetic protein type IB receptor and Smadl signaling by anti-mullerian hormone and its type II receptor. Journal of Biological Chemistry 275:27973-27978.

Gougeon, A. 1996. Regulation of ovarian follicular development in primates: facts and hypotheses. Endocrine Reviews 17:121-155.

Gougeon, A., Ecochard, P., Christophe, T.J. 1994. Age-related changes of the population of human ovarian follicles: increase in the disappearance rate of non-growing and earlygrowing follicles in aging women. Biology of Reproduction 50:653-663.

Govignon A., Rohou, A., Ponsart, C., Delcroix, P., Humblot, P. 2000. Sources of variation of embryo production after superovulation in Prim Holstein dairy cows. In: 16th Reunion de la A. E. T. E, 8-9:158 Santander, Spain.

Greve,T., Callesen, H., Hyttel, P., Hoier, R., Assey, R. 1995. Effect of exogenous gonadotropins in oocyte and embryo quality in cattle. Theriogenology 43:41-50.

Grondahl, M.L., Nielsen, M.E., Dal Canto, M.B., Fadini, R., Rasmussen, I.A., Westergaard, L.G., Kristensen, S.G., Yding Anderson, C. 2011. Anti-mullerian hormone remains highly expressed in human cumulus cells during the final stages of folliculogenesis. Reproduction Biomedical Online 22:389-398.

Grossman, M.P., Nakajima, S.T., Fallat, M.E., Siow, Y. 2008. Müllerian-inhibiting substance inhibits cytochrome P450 aromatase activity in human granulosa lutein cell culture. Fertility and Sterility 89:1364-1370.

Gruijters, M.J.G., J.A. Visser, A.L.L. Durlinger, A.P.N. Themmen.2003. Anti-Mullerian hormone and its role in ovarian function. Molecular and Cellular Endocrinology 211:8590 .

Guerreiro, B.M., Batista, E.O.S., Vieira, L.M., Sá Filho, M.F., Rodrigues, C.A., Castro Netto, A., Silveira, C.R.A., Bayeux, B.M., Dias, E.A.R., Monteiro, F.M., Accorsi, M., Lopes, R.N.V.R., Baruselli, P.S. 2014. Plasma Anti-Mullerian Hormone: An Endocrine Marker for in Vitro Embryo Production from Bos Taurus and Bos Indicus Donors. Domestic Animal Endocrinology 49:96-104.

Haqq, C.M., King, C.Y., Ukiyama, E., Falsafi, S., Haqq, T., Donahoe, P.K., Weiss, M.A. 1994. Molecular basis of mammalian sex determination: activation of Mullerian inhibiting substance gene expression by SRY. Science 266:1494-1500.

Hasler, J.F. 2014. Forty Years of Embryo Transfer in Cattle: A Review Focusing on the Journal Theriogenology, the Growth of the Industry in North America, and Personal Reminisces. Theriogenology 81:152-69. 
Haughian, J.M., Ginther, O.J., Kot, K., Wiltbank, M.C. 2004. Relationship between FSH patterns and follicular dynamics and the temporal associations among hormones in natural and GnRH-induced gonadotrophin surges in heifers. Reproduction 127:23-33.

Hayes, B.J., Lewin, H.A., Goddard, M.E. 2013. The future of livestock breeding: genomic selection for efficiency, reduced emissions intensity and adaptation. Trends in Genetics 29:206-214.

Hazout, A., Bouchard, P., Seifer, D.B., Aussage, P., Junca, A.M., Cohen-Bacrie, P. 2004. Serum antimullerian hormone/mullerian-inhibiting substance appears to be more discriminatory marker of assisted reproductive technology outcome than follicle stimulating hormone, inhibin B or estradiol. Fertility and Sterility 82:1323-1329.

Hehenkamp, W.J., Looman, C.W., Themmen, A.P., de Jong, F.H., Te Velde, E.R., Broekmans, F.J. 2006. Anti-Mullerian hormone levels in the spontaneous menstrual cycle do not show substantial fluctuation. Journal of Clinical Endocrinology and Metabolism 91:40574063.

Henao G, M. Oliver-Anger, J.G. Maldoado-Estrada. 2000. Follicular dynamics during postpartum anestrous and the first estrous cycle in suckled or non-suckled Brahman (Bos indicus) cows. Animal Reproduction Science 63:127-136.

Henryon, M., Berg, P., Sorensen, A.C. 2014. Animal-breeding schemes using genomic information need breeding plans designed to maximize long-term genetic gains. Livestock Science 166:38-47.

Hirayama, H., Naito, A., Fukuda, S., Fujii, T., Asada, M., Inaba, Y., Takedomi, T., Kawamata, M., Moriyasu, S., Kageyama, S. 2017. Long-term changes in plasma anti-Mullerian hormone concentration and the relationship with superovulatory response in Japanese Black cattle. Journal of Reproduction and Development 63:95-100.

Hirobe, S., He, W.W., Lee, M.M., Donahue, P.K. 1992. Mullerian inhibiting substance messenger ribonucleic acid expression in granulosa and sertoli cells coincides with their mitotic activity. Endocrinology 133:854-862.

Hollinshead, F. K., C. Walker, D. W. Hanlon. 2016. Determination of the normal reference interval for anti-mullerian hormone (AMH) in bitches and use of $\mathrm{AMH}$ as a potential predictor of litter size. Reproduction in Domestic Animals 51:1-6.

Hudson,P.L., Douglas, I., Donahoe, P.K., Cate, R.L., Epstein, J., Pepinsky, R.B., MacLaughlin, D.T. 1990. An immunoassay to detect human mullerian inhibiting substance in males and females during normal development. Journal of Clinical Endocrinology and Metabolism 7091:16-22. 
Hunter, M.G., Robinson, R.S., Mann, G.E., Webb, R. 2004. Endocrine and paracrine control of follicular development and ovulation rate in farm species. Animal Reproduction Science 82-83:461-477.

Ireland J.J., Smith, G.W., Scheetz, D., Jimenez-Krassel, F., Folger, J.K., Ireland, J.L.H., Mossa, F., Lonergan, P., Evans, A.C.O. 2010. Does size matter in females? An overview of the impact of the high variation in the ovarian reserve on ovarian function and fertility, utility of anti-Müllerian hormone as a diagnostic marker for fertility and causes of variation in the ovarian reserve in cattle. Reproduction Fertility and Development 23:1-14.

Ireland, J., Ward, F., Jimenez-Krassel, F., Ireland, J.L., Smith, G.W., Lonergan, P., Evans, A.C.O. 2007. Follicle numbers are highly repeatable within individual animals but are inversely correlated with FSH concentrations and the proportion of good-quality embryos after ovarian stimulation in cattle. Human Reproduction 22:1687-1695.

Ireland, J.J., Smith, G.W., Scheetz, D., Jimenez-Krassel, F., Folger, J.K., Ireland, J.L.H., Mossa, F., Lonergan, P., Evans, A.C.O. 2011. Does size matter in females? An overview of the impact of the high variation in the ovarian reserve on ovarian function and fertility, utility of anti-Mullerian hormone as a diagnostic marker for fertility and causes of variation in the ovarian reserve in cattle. Reproduction. Fertility and Development 23:1-14.

Ireland, J.J., Zielak-Steciwko, A.E., Jimenez-Krassel, F., Folger, J., Bettegowda, A., Scheetz, D., Walsh, S., Mossa, F., Knight, P.G., Smith, G.W., Lonergan, P., Evans, A.C. 2009. Variation in the ovarian reserve is linked to alterations in intrafollicular estradiol production and ovarian bio- markers of follicular differentiation and oocyte quality in cattle. Biology of Reproduction 80:954-64.

Ireland, J.L.H., Scheetz, D., Jimenez-Krassel, F., Themmen, A.P.N., Ward, F., Lonergan, P., Smith, G.W., Perez, G.I., Evans, A.C.O., Ireland, J.J. 2008. Antral follicle count reliably predicts number of morphologically healthy oocytes and follicles in ovaries of young adult cattle. Biology of Reproduction 79:1219-1225.

Isobe, N., Yoshimura, Y. 2000. Immunocytochemical study of cell proliferation in cystic ovarian follicles in cows. Theriogenology 54:1159-1169.

Jamin, S.P., Arango, N.A., Mishina Y., Hanks, M.C., Behringer, R.R. 2002. Requirement of Bmprla for Müllerian duct regression during male sexual development. Nature Genetics 32:408-410.

Jimenez-Krassel, F., Scheetz, D.M., Neuder, L.M., Ireland, J.L.H., Pursley, J.R., Smith, G.W., Tempelman, R.J., Ferris, T., Roudebush, W.E., Mossa, F., Longergan, P., Evans, A.C.O., Ireland, J.J. 2015. Concentration of anti-müllerian hormone in dairy heifers is positively associated with productive herd life. Journal of Dairy Science 98:3036-3045.

Jost, A. 1947. Recherches sur la differenciation sexuelle de l' embryon de lapin. Arch Anat Microsc morphol Exp 36:271-315. 
Kafi, M., Mcgowan, M. 1997. Factors associated with variation in the superovulatory response in cattle. Animal Reproduction Science 46:1-14.

Kahapola Arachchige, K.M., Wardrop, R., Lim, W.M., Stuckey, B., Hadlow, N. 2012. Waiting for an elevated FSH - Too late a marker of reduced ovarian reserve? Australian and New Zealand Journal of Obstetrics and Gynaecology 52:460-464.

Kahi, A.K., Rewe, T.O. 2008. Biotechnology in livestock production: Overview of possibilities for Africa. African Journal of Biotechnology 7:4984-4991.

Kelly P., Duffy, P., Roche, J.F., Boland, M.P. 1997. Superovulation in cattle: Effect of FSH type and method of administration on follicular growth, ovulatory response and endocrine patterns. Animal Reproduction Science 46:1-14.

Kenyon, P. R., A.N. Thompson, S.T. Morris. 2014. Breeding ewe lambs successfully to improve lifetime performance. Small Ruminant Research 118:2-15.

Kenyon, P., D. van der Linden, D. West, S. Morris. 2011. The effect of breeding hoggets on lifetime performance. New Zealand Journal of Agricultural Research 54:321-330.

Kevenaar, M.E., Meerasahib, M.F., Kramer, P., van de Lang-Born, B.M., de Jong, F.H., Groome, N.P, Themmen, A.P., Visser, J.A. 2006. Serum antimullerian hormone levels reflect the size of the primordial follicle pool in mice. Endocrinology: 147:3228-3234.

Knight, P.G., C. Glister. 2006. TGF- $\beta$ superfamily members and ovarian follicle development. Reproduction 132:191-206.

Knight, P.G., Glister, C. 2003. Local roles of TGF- $\beta$ superfamily members in the control of ovarian follicle development. Animal Reproduction Science 78:165-183.

Knights,M., A.Redhead, K.D'Souza, Q.Baptiste. 2015. Effect of stimulation with a gonadotropin mixture on reproductive outcome in nulliparous ewes bred during seasonal anestrus and early breeding season. Animal Reproduction Science 159:198-204.

Knopf, L., Kastelic, J.P., Schallenberger, E., Ginther, O.J. 1989. Ovarian follicular dynamics in heifers: test of two-wave hypothesis by ultrasonically monitoring individual follicles. Domestic Animal Endocrinology 6:111-19.

Kotanidis, L., Asimakopoulos, B., Nikolettos, N. 2013. Association between AMH, oocyte number and availability of embryos for cryopreservation in IVF. International Journal of Experimental and Clinical Pathophysiology and Drug Research in vivo 27:877-880.

Kulick L. J., K. Kot, M.C. Wiltbank. 1999. Follicular and hormonal dynamics during the first follicular wave in heifers. Theriogenology 52:913-921. 
La Marca, A., Malmusi, S., Giulini, S., Tamaro, L.F., Orvieto, R., Levratti, P., Volpe, A. 2004. Anti-Mullerian hormone plasma levels in spontaneous menstrual cycle and during treatment with FSH to induce ovulation. Human Reproduction 19:2738-41.

La Marca, A., Stabile, G., Artenisio, A.C., Volpe, A. 2006. Serum anti-mullerian hormone throughout the human menstrual cycle. Human Reproduction 21:3103-7.

Lahoz B., Alabart, J.L., Monniaux, D., Echegoyen, E., Sanchez, P., Folch, J. 2014. AntiMullerian hormone concentration in sheep and its dependence of age and independence of BMP-15 genotype: an endocrine predictor to select the best donors for embryo biotechnologies. Theriogenology 81:347-357.

Lahoz, B., J. L. Alabart, D. Monniaux, P. Mermillod, J. Folch. 2012. Anti-Müllerian Hormone Plasma Concentration in Prepubertal Ewe Lambs as a Predictor of Their Fertility at a Young Age. BMC Veterinary Research 8:118.

Le Nestour, E., Marraoui, J., Lahlou, N., Roger, M., de Ziegler, D. Bouchard, P. 1993. Role of estradiol in the rise in follicle stimulating hormone levels during the luteal-follicular transition. Journal of Clinical Endocrinology and Metabolism 77:439-442.

Lehmann, P. M.P. Velez, J. Saumet, L. Lapensee, W. Jamal, F. Bissonnette, S. Phillips, I.J. Kadoch. 2014. Anti-Mullerian hormone (AMH): a reliable biomarker of oocyte quality in IVF. Journal of Assited Reproduction Genetics 31:493-498.

Lerner S.P., Thayne, W.V., Baker, R.D., Henschen, T., Meredith, S., Inskeep, E.K., Dailey, R.A., Lewis, P.E., Butler, R.E. 1986. Age, dose of FSH and other factors affecting superovulation in Holstein cows. Journal of Animal Science 63:176-183.

Li, D.R., Quin, G.S., Wei, Y.M., Lu, F.H., Huang, Q.S., jiang, H.S., Shi, D.S., Shi, Z.D. 2011. Immunization against inhibin enhances follicular development, oocyte maturation and superovulatory response in water buffaloes. Reproductive Fertility and Development 23:788-797.

Lindsell, C.E., Rajkumar, K., Manning, A.W., Emery, S.K., Maplesoft, R.J., Murphy, B.D. 1986. Variability in FSH:LH ratios among batches of commercially available gonadotropins. Theriogenology 25:167.

Lintern-Moore,S., Moore, G.P. 1979. The initiation of follicle and oocyte growth in the mouse ovary. Biology of Reproduction 20:773-778.

Little M, Wells, C.1997. A clinical overview of WT-1 gene mutations. Human Mutations 9:209225.

Liu, K.E., Greenblatt, E.M. 2008. Elevated day 3 follicle stimulating hormone/luteinizing hormone ratio $\geq 2$ is associated with higher rates of cancellation in in vitro fertilizationembryo transfer cycles. Fertility and Sterility 90:297-301. 
Looney, C.R., Bondioli, K.R., Hill, K.G., Massey, J.M. 1988. Superovulation of donor cows with bovine follicle stimulating hormone produced by recombinant DNA technology. Theriogenology 29:271.

Lopes da Costa, L., Chagas Silva, J., Robalo Silva, J. 2001. Treatment with Different Gonadotropins in Native Cattle. Theriogenology 56:65-77.

Lucy,M.C., Staples, R.C., Michel, M.F., Thatcher, W.W. 1991. Energy balance and size of ovarian follicles detected by ultrasonography in early postpartum dairy cows. Journal of Dairy Science 74:473-482.

Majumder,K., Gelbaya, T.A., Laing,I., Nardo, L.G. 2010. The use of anti-Mullerian hormone and antral follicle count to predict the potential of oocytes and embryos. European Journal of Obstetrics, Gynecology and Reproductive Biology 150:166-170.

Madan, M.L. 2005. Animal biotechnology: applications and economic implications in developing countries. Revue scientifique et technique (International Office of Epizootics) 24:127-139.

Madan, M.L., Das, S.K., Palta, P. 1996. Application of reproductive technology to buffaloes. Animal Reproduction Science, 42:299-306.

Majumder, K., Gelbaya, T.A., Laing, I., Nardo, L.G. 2010. The use of anti-Mullerian hormone and antral follicle count to predict the potential of oocytes and embryos. European journal of Obstetrics and Gynecology and Reproductive Biology 150:166-170.

Malhado,C.H., A.C. Malhado, P.L. Carneiro, A.A. Ramos, D.P. Ambrosini, A. Pala. 2012. Population structure and genetic variability in the Murrah dairy breed of water buffalo in Brazil accessed via pedigree analysis. Tropical animal health and production 44:18911897.

Malhi, P.S, Adams, G.P., Mapletoft, R.J., Singh, J. 2007. Oocyte developmental competence in a bovine model of reproductive aging. Reproduction 134:233-239.

Malhi, P.S. 2005. Bovine Model for the study of reproductive aging in women: Follicular, luteal and endocrine. Biology of Reproduction 73:45-53.

Malhi, P.S., Adams, P.G., Mapletoft, R.J., Singh, J. 2008. Superovulatory response in a bovine model of reproductive aging. Animal Reproduction Science 109:100-109.

Mapletoft, R.J., Gonzalez, A., Lussier, J.G. 1988. Superovulation of beef heifers with Folltropin or FSH-P. Theriogenology 29:274. (Abstract). 
Martinez, G.E., Koch, R.M., Cundiff, L.V., Gregory, K.E., Van Vleck, L.D. 2004. Genetic parameters for six measures of length of productive life and three measures of lifetime production by $6 \mathrm{yr}$ after first calving for Hereford cows. Journal of Animal Science 82:1912-1918.

Massaque, J. 1990. The transforming growth factor-beta family. Annual Review of Cell Biology 6:597-641.

Matuk, M.M., Burns, K.H., Viveiros, M.M., Eppig, J.J. 2002. Intercellular communication in the mammalian ovary: oocytes carry the conversation. Science 296:2178-2180

McGee, E.A., Hsueh, A.J. 2000. Initial and cyclic recruitment of ovarian follicles. Endocrine Reviews 21:200-214.

McGee, E.A., R. Smith, N. Spears, M.W. Nachtigal, H. Ingraham, A.J. Hsueh. 2001. Mullerian inhibitory substance induce growth or rat preantral ovarian follicles. Biology of Reproduction 64:293-298.

McNatty, K.P., Hillier, S.G., van den Boogaard, A.M., Trimbos-Kemper, T.C., Reichert, L.E., van Hall, E.V.1983. Follicular development during the luteal phase of the human menstrual cycle Journal of Clinical Endocrinology and Metabolism 56:1022-1031.

Mihm M., Baker, P.J., Ireland, J.L., Smith, G.W., Coussens, P.M., Evans, A.C., Ireland, J.J. 2006. Molecular evidence that growth of dominant follicles involves a reduction in follicle-stimulating hormone dependence and an increase in luteinizing hormone dependence in cattle. Biology of Reproduction 74:1051-1059.

Mihmn, M., Austin, E.J. 2002. The final stages of dominant follicle selection in cattle. Domestic Animal Endocrinology 23:155-166.

Mikkelsen, A.L., Andersson, A.M., Skakkebaek, N.E., Lindenberg, S. 2001. Basal Concentrations of Oestradiol May Predict the Outcome of in vitro maturation in regularly menstruating women. Human Reproduction 16:862-867.

Mishina, Y., Rey, R., Finegold, M.J., Matzuk, M.M., Josso, N., Cate, R.L., Behringer, R.R. 1996. Genetic analysis of the Müllerian-inhibiting substance signal transduction pathway in mammalian sexual differentiation. Genes Development 10:2577-2587.

Misra, A.K., S. Tyagi. 2007. In vivo embryo production in buffalo: present and perspectives. Italian Journal of Animal Science 6:74-91.

Mondadori, R.G., Luque, M.C.A., Santin, T.R., Bao, S.N. 2007. Ultrastructural and morphometric characterization of buffalo (Bubalus bubalis) ovarian preantral follicles. Animal Reproduction Science 97:323-333. 
Mondadori, R.G., Santin, T.R., Fidelis, A.A.G., porfitio, E.P., Bao, S.N. 2010. Buffalo (Bubalus bubalis) pre-antral follicle population and ultastrctural characterization of antral follicle oocyte. Reproduction in Domestic Animals 45:33-37.

Monniaux D, Drouilhet L, Rico C, Estienne A., Jarrier P., Touze J.L., Sapa J., Phocas F., Dupont J., Dalbies-Tran R. 2013. Regulation of anti- Mullerian hormone production in domestic animals. Reproduction, Fertility and Development 25:1-16.

Monniaux, D., Barbey, S., Rico, C., Fabre, S., Gallard, Y., Larroque, H. 2010. Anti-Mullerian hormone: a predictive marker of embryo production in cattle? Reproduction, Fertility and Development 22:1083-1091.

Monniaux, D., Baril, G., Laine, A.L., Jarrier, P., Poulin, N., Cognié, J., Fabre, S. 2011. Antimullerian hormone as a predictive endocrine marker for embryo production in the goat. Reproduction 142:845-854.

Monniaux, D., Drouilhet, L., Rico, C., Estienne, A., Jarrier, P., Touze, J.L., Sapa, J., Phocas, F., Dupont, J., Dalbies-Tran, R. 2013. Regulation of anti- mullerian hormone production in domestic animals. Reproduction, Fertility and Development 25:1-16.

Monniaux, D., Drouilhet, L., Rico, C., Estienne, A., Jarrier, P., Touze, J.L., Sapa, J., phocas, F., Dupont, J., Dalbies-Tran, R., Fabre, S. 2012. Regulation of anti-Mullerian hormone production in domestic animals. Reproduction Fertility and Development 25:1-16.

Mukherjee, T., Copperman, A.B., Lapinski, R., Sandler, B., Bustillo, M., Grunfield, L. 1996. An elevated day 3 follicle stimulating hormone: luteinizing hormone ration (FSH: LH) in the presence of a normal day 3 FSH predicts a poor response to controlled ovarian hyperstimulation. Fertility Sterility 65:588-93.

Mulders, A.G, Laven, J.S., Eijkemans, M.J., de Jong, F.H., Themmen, A.P.N., Fauser, B.C. 2004. Changes in anti-Mullerian hormone serum concentrations over time suggest delayed ovarian ageing in normogonadotrophic anovulatory infertility. Human Reproduction 19:2036-2042.

Munsterberg, A., Lovell-Badge, R. 1991. Expression of the mouse anti-müllerian hormone gene suggest a role in both male and female sexual differentiation. Development 113:613-624.

Murphy, B., Mapletoft, R., Manns, J., Humphrey, W. 1984. Variability in gonadotropin preparations as a factor in the superovulatory response. Theriogenology 21:117-125.

Muttukrishna, S., Suharjono, H., McGarrigle, H., Sathanandan, M. 2004. Inhibin B and antimullerian hormone: markers of ovarian response in IVF/ICSI patients? BJOG International Journal of Obstetrics and Gynaecology 3:1248-1253. 
Nachtigal, M, Hirokawa, Y., Enyeart-VanHouten, D.L., Flanagan, I.N., Hammer, G.D., Ingraham, H.A. 1998. Wilms' tumor I and Dax-1 modulate the orphan nuclear receptor SF-I in sex-specific gene expression. Cell 93:445-454.

Nardo, L.G., Gelbaya, T.A., Wilkinson, H., Roberts, S.A., Yates, A. Pemberton, P., Liang, I. 2009. Circulating basal anti-mullerian hormone levels as predictor of ovarian response in women undergoing ovarian stimulation for in vitro fertilization. Fertility and Sterility 92:1586-1593.

Neglia, G. Gasparrini, B., Di Palo, R., De Rosa, C., Zicarelli, L., Campanille, G. 2003. Comparison of pregnancy rates with two estrus synchronization protocols in Italian Mediterranean Buffalo cows. Theriogenology 60:125-133.

Neglia, G., Gasparrini, B., Vecchio, D., Rubessa, M., Di Palo, R., Zicarelli, L. Campanile, G. 2010. Progesterone supplementation during multiple ovulation treatment in buffalo species (Bubalus bubalis).Tropical Animal Health Production 6:1243-1247.

Neglia, G., Natale, A., Esposito, G., Salzillo, F., Adinolfi, L., Zicarelli, L., Francillo, M. 2007. Follicular dynamics in synchronized Italian Mediterranean buffalo cows. Italian Journal of Animal Science 6:611-614.

Noci, I., Biagiotti, R., Maggi, M., Ricci, F., Cinotti, A., Scarselli, G. 1998. Low day 3 luteinizing hormone values are predictive of reduced response to ovarian stimulation. Human Reproduction 13:531-534.

Page, R.D., Jordan, J.E., Johnson, S.K. 1985. Superovulation of Holstein heifers under heat stress with FSHp or Follotropin. Theriogenology 31:236.

Pellatt, L., Hanna, L., Brincat, M., Galea, R., Brain, H., Whitehead, S., Mason, H. 2007. Granulosa cell production of anti-Mullerian hormone is increased in polycystic ovaries. Journal of Clinical Endocrinology and Metabolism 92:240-245.

Pellatt, L., Rice, S., Dilaver, N., Heshri, A., Galea, R., Brincat, M., Brown, K., Simpson, E., Mason, H. 2011. Anti-Müllerian hormone reduces follicle sensitivity to folliclestimulating hormone in human granulosa cells. Fertility and Sterility 96:1246-1251.

Pelletier J., Schalling, M., Buckler, A.J., Rogers, A., Haber, D.A., Housman, D. 1991. Expression of the Wilms' tumor gene WT-1 in the murine urogenital system. Genes Development 5:1345-1356.

Pepinsky, R.B., Sinclair, L.K., Chow, E.P., Mattaliano, R.J., Manganaro, T.F., Donahoe, P.K., Cate, R.L. 1988. Proteolytic processing of Müllerian-inhibiting substance produces a transforming growth factor-beta-like fragment. Journal of Biological Chemistry 263:18961-18964. 
Perloe, M., Levy, D.P., Sills, E.S. 2000. Strategies for ascertaining ovarian reserve among women suspected of subfertility. International Journal of Fertility and Women's Medicine 45:215-224.

Peschon, J.J., Behringer, R.R., Cate, R.L., Harwood, K.A., Idzerda, R.L., Brinster, R.L., Palmiter, R.D. 1992. Directed expression of an oncogene to Sertoll cells in transgenic mice using Mullerian-inhibiting substance regulatory sequences. Molecular Endocrinology 1403-1411.

Peter, A.T., Levine, H., Drost, M., Bergfelt, D.R. 2009. Compliation of classical and contemporary terminology used to describe morphological aspects of ovarian dynamics in cattle. Theriogenology 71:1343-1357.

Peters, K.E., Bergfeld, E.G., Cupp, A.S., Kojima, F.N., Mariscal, V., Sanchez, T., Wehrman, M.E., Grotjan, H.E., Hamernik, D.L., Kittok, R.J. 1994. Luteinizing hormone has a role in development of fully functional corpora lutea $(\mathrm{CL})$ but is not required to maintain CL function in heifers. Biology of Reproduction 51:1248-1254.

Pfeiffer, K.E., Jury, L.J., Larson, J.E. 2014. Determination of anti-müllerian hormone at estrus during a synchronized and a natural bovine estrous cycle. Domestic Animal Endocrinology 46:58-64.

Picard, J.Y., Benarous, R., Guerrier, D., Josso, N., Kahn, V. 1986. Cloning and expression of cDNA for anti-müllerian hormone. Proceedings of the National Academy of Science USA 83:5464-5468.

Picton, H.M., Tsonis, C.G., McNeilly, A.S. 1990. The antagonistic effect of exogenous LH pulses on FSH-stimulated preovulatory follicle growth in ewes chronically treated with a gonadotropin-releasing hormone agonist. Journal of Endocrinology 127:273-283.

Picton, H.M. 2001. Activation of follicle development: the primordial follicle. Theriogenology 55:1193-1210.

Pivton, H.M., Harris, S.E., Muruvi, W., Chambers, E.L. 2008. The in vitro growth and maturation of follicles. Reproduction 136:703-715.

Piltonen, T., Morin-Papunen, L., Koivunen, R., a.Perheentupa, A., Ruokonen, A., Tapanainen, J.S. 2005. Serum anti-Mullerian hormone levels remain high until late reproductive age and decrease during metformin therapy in women with polycystic ovary syndrome. Human Reproduction 20:1820-1826.

Prapa, E., Vasilaki, A., Dafopoulos, K., Katsiani, E., Georgoulias, P., Messini, C.I., Anifandis, G., Messinis, I.E. 2015. Effect of Anti-Mullerian hormone (AMH) and bone mprphogenetic protein 15 (BMP-15) onsteroidogenesis in primary-cultured human luteinizing granulosa cells through Smad5 signaling. Journal of Assisted Reproduction and Genetics 32:1079-1088. 
Quaresma, M.A., Lopes Costa, L., Robalo Silva, J. 2003. Superovulation of mertolenga cows with two FSH Preparations ( FSH-P and FOLLTROPIN ) Medicina 98:81-84.

Quirke J.F, J.P. Hanrahan.1977. Comparison of the survival in the uteri of adult ewes of cleaved ova from adult ewes and ewe lambs. Journal of Reproduction and Fertility 51:487-489.

Qureshi, M.S., S. Khan, N. Ahmad.2007. Pregnancy depresses milk yield in dairy buffaloes. Italian Journal of Animal Science 6:1290-1293.

Ramli B.A., Wan, K.W.E, Hui, H.S. 2011. Biotechnology in Animal Production in Developing Countries. Animal Biotechnology-Embryo Laboratory, Institute of Biological Sciences, Faculty of Science, University of Malaya, 50603 Kuala Lumpur, Malaysia. 2nd International Conference on Agricultural and Animal Science IPCBEE vol. 22 Singapore.

Ravindra, J.P., Rawlings, N.C., Evans, A.C.O., Adams, G.P. 1994. Ultrasonographic study of ovarian follicular dnamics in ewes during the oestrous cycle. Journal of Reproduction and Fertility 101:501-509.

Rastogi, L. Rastogi, R.K. 2004. Buffalypso: The Water Buffaloes of Trinidad and Tobago. An Occasional Publication of the Livestock and Livestock Products Board, Trinidad and Tobago 13.

Renquist, B.J., Oltjen, J.W., Sainz, R.D., Calvert, C.C. 2006. Effects of age on body condition and production parameters of multiparous beef cows. Journal of Animal Science 84:1890-1895.

Rhodes, F.M., Death, G., Entwistle, K.W. 1995. Animal and temporal effects on ovarian follicular dynamics in Brahman heifers. Animal Reproduction Science 38:265-277.

Ribeiro, E.S., Bisinotto, R.S., Lima, F.S., Greco, L.F., Morrison, A., Kumar, A., Thatcher, W.W., Santos, J. E.P. 2014. Plasma anti-müllerian hormone in adult dairy cows and associations with fertility. Journal of Dairy Science 97:6888-6900.

Rico C., Fabre S., C, Medigue, N. di Clemente , F. Clement, M. Bontoux ,J.L. Touze, M. Dupont, E. Briant, B. Remy. 2009. Anti-mullerian hormone is an endocrine marker of ovarian gonadotropin-responsive follicles and can help to predict superovulatory responses in the cow. Biology of Reproduction 80:50-59.

Rico, C., Drouilhet, L., Salvetti, P., Dalbiès-Tran, R., Jarrier, P., Touzé, J.L., Pillet, E., Ponsart, C., Fabre, S., Monniaux, D. 2012. Determination of anti-Müllerian hormone concentrations in blood as a tool to select Holstein donor cows for embryo production: from the laboratory to the farm. Reproduction Fertility Development 24:932-944. 
Rico, C., Medigue, C., Fabre, S., Jarrier, P., Bontoux, M., Clement, F., Monnaiaux, D. 2011. Regulation of Anti-Mullerian Hormone Production in the Cow: A multiscale study at endocrine, ovarian, follicular and granulosa cell levels. 2011. Biology of Reproduction 84:560-571.

Roosa, K.A., D.A. Zysling, N.J. Place. 2016. An assessment of anti-mullerian hormone in predicting mating outcomes in female hamsters that have undergone natural and chemically-accelerated reproductive aging. General and comparative endocrinology 214:56-61.

Rosales-Nieto, C.A., M.B. Ferguson, C.A. Macleay, J.R. Briegel, D.A. Wood, G.B. Martin, A.N. Thompson. 2013. Ewe lambs with higher breeding values for growth achieve higher reproductive performance when mated at age 8 months. Theriogenology 80:427-435.

Rosegrant, M.W., Fernandez, M., Sinha, A., Alder, J., Ahammad, H., de Fraiture, C., Eickhour, B., Fonseca, J., Huang, J., Koyama, O., Omezzine, A., Pingali, P., Ramirez, R., Ringler, C., Robinson, S., Thornton, P., van Vuuren, D., Yana-Shapiro, H. 2009 Looking into the future for agriculture and AKST (Agricultural Knowledge Science and Technology). In Agriculture at a crossroads (eds B. D. McIntyre, H. R. Herren, J. Wakhungu \& R. T. Watson), pp. 307-376. Washington, DC: Island Press.

Rosen, M.P., Johnstone, E., McCulloch, C.E., Schuh-Huerta, S.M., Sternfeld, B., Reijo-Pera, R.A., Cedars, M.I. 2012. A characterization of the relationship of ovarian reserve markers with age. Fertility and Sterility 97:238-243.

Roudebush, W.E., Kivens, W.J., Mattke, J.M. 2008. Biomarkers of ovarian reserve. Biomarker Insights 16:259-268.

Salmon, N.A., Handyside, A.H., Joyce, I.M. 2004. Oocyte regulation of anti-Mullerian hormone expression in granulosa cells during ovarian follicle development in mice. Development Biology 266:201-208.

Samad, H.A., Nasseri, A.A. 1979. A quantitative study of primordial follicles in buffalo heifer ovaries. In: Comp. $13^{\text {th }}$ FAO/SIDA International Course Animal Reproduction, Uppsala, Sweden. Uppsala Sweden.

Santa Barbara, P., Bonneaud, N., Boizet, B., Desclozeaux, M., Moniot, B., Sudbeck, P., Scherer, G., Poulat, F., Berta, P. 1998. Direct interaction of SRY-related protein SOX9 and steroidogenic factor 1 regulates transcription of human anti-mullerian hormone gene. Molecular Cell Biology 18:6653-6665.

Santana,M.L., R.R. Aspilcueta-Borquis, A.B. Bignardi, L.G. Albuquerque, H. Tonhati. 2011. Population structure and effects of inbreeding on milk yield and quality of Murrah buffaloes. Journal of Dairy Science 94:5204-5211. 
Saumande J., Chupin, D. 1986. Induction of superovulation in cyclic heifers. The inhibitory effect of large doses of PMSG. Theriogenology 25:233-247.

Sartori,R., Bastos, M.R., Baruselli, P.S., Gimenes, L.U., Ereno, R.L., Barros, C.M. 2009. Physiological differences and implications to reproductive management of Bos taurus and Bos indicus cattle in a tropical environment. Society of Reproduction and Fertility supplement 67:357-375.

Scaramuzzi, R. J., Baird, D.T., Campbell, B.K., Driancourt, M.A., Dupont, J., Fortune, J.E., Gilchrist, R.B., Martin, G.B., McNat-ty, K.P., McNeilly, A.S., Monget, P., Monniaux, D., Vinoles, C., Webb, R. 2011. Regulation of folliculogenesis and the determination of ovulation rate in ruminants. Reproduction Fertility and Development 23:444-467.

Scheetz, D., Folger, J.K., Smith, G.W., Ireland, J.J. 2012. Granulosa cells are refractory to FSH action in individuals with a low antral follicle count. Reproduction Fertility and Development. 24:327-336.

Schipper, I., Hop, W.C., Fauser, B.C. 1998. The follicle stimulating hormone threshold/window concept examined by different interventions with exogenous FSH during the follicular phase of the normal menstrual cycle: duration, rather than magnitude, of FSH increase affects follicle development. Journal of Clinical Endocrinology and Metabolism 83:12921298.

Seifer, D.B., Maclaughlin, D.T. 2007. Müllerian Inhibiting Substance is an ovarian growth factor of emerging clinical significance. Fertility and Sterility 88:539-46.

Seifer, D.B., MacLaughlin, D.T., Christian, B.P., Feng, B., Shelden, R.M. 2002. Early follicular serum mullerian-inhibiting substance levels are associated with ovarian response during assisted reproductive technology cycles. Fertility and Sterility 77:468-471.

Seifer, D.B., Messerlian, G.L., Hogan, J.W., Gardiner, A.C., Blazar, A.S., Berk, C.A. 1997. Day 3 serum inhibin $B$ is predictive of assisted reproductive technologies outcome. Fertility and Sterility 67:110-114.

Seifer,D.B., Scott, R.T., Bergh, P.A., Abrogast, L.K., Friedman, C.I., Mack, C.K., Danforth, D.R. 1999. Women with declining ovarian reserve may demonstrate a decrease in day 3 serum inhibin B before a rise in day 3 follicle stimulating hormone. Fertility and Sterility 72:63-65.

Senger, P.L. 2005 Pathways to Pregnancy and Parturition $3^{\text {rd }}$ edition, Pullman, WA: Current Conceptions.

Shelton, J.N. 1990. Reproductive technology in animal production. Revue scientifique et technique (International Office of Epizootics) 9:825-845. 
Shen, W.H., Moore, C.C., Ikeda, Y., Parker, K., Ingraham, H. A. 1994. Nuclear receptor steroidogenic factor 1 regulates the mullerian inhibiting substance gene: a link to the sex determination cascade. Cell 77:651-61.

Shrim, A., Elizur, S.E., Seidman, D.S., Rabinovici, J., Wiser, A., Dor, J. 2006. Elevated day 3 FSH/LH ratio due to low $\mathrm{LH}$ concentrations predicts reduced ovarian response. Reproduction biomed Online 12:418-22.

Silva-Santos, K.C., Santos, G.M.G., Junior, C.K., Morotti, F., Siloto, L.S., Marcantonio, T.N., Urbano, M.R., Oliveira, R.L., Lima, D.C.M., Seneda, M.M. 2014. Antral follicle populations and embryo production in vitro and in vivo of Bos indicus-taurus Donors from Wearing to Yearling Ages .Reproduction in Domestic Animals 49:228-232.

Singh,J. A.S. Nanda, G.P. Adams. 2000. The reproductive pattern and efficiency of female buffaloes. Animal Reproduction Science 60-61:593-604.

Singh,N., G.S. Dhaliwal, V.S. Malik, D. Dadarwal, M. Honparkhe, S. Singhai, P.S. Brar. 2015. Comparison of follicular dynamics, superovulatory response, and embryo recovery between estradiol based and conventional superstimulation protocol in buffaloes (Bubalus bubalis). Veterinary World 8:983-988.

Sirois, J., Fortune, J.E. 1988. Ovarian follicular dynamics during the estrous cycle in heifers monitored by real-time ultrasonography. Biology of Reproduction 39:309-317.

Smeenk, J.M., Sweep, F.C., Zielhuis, G.A., Kremer, J.A., Thomas, C.M., Braat, D.D. 2007. Anti mullerian hormone predicts ovarian responsiveness, but not embryo quality or pregnancy, after in vitro fertilization or intra-cytoplasmic sperm injection. Fertility Sterility 87:223226.

Smidt, D., Niemann, H. 1999. Biotechnology in genetics and reproduction. Livestock production Science 59:207-221.

Smith,V., T. Osianlis, B. Vollenhoven.2014. A review of luteinizing hormone and its role in ovarian reserve testing. International Journal of Reproduction, Contraception, Obstetrics and Gynecology 3:11-18.

Smotrich, D.B., Widra, E.A., Gindoff, P.R., Levy, M.J., Hall, J.L., Stillman, R.J.1995. Prognostic value of day 3 estradiol on in vitro fertilization outcome. Fertility Sterility 64:1136-1140.

Songsasen N., Yiengvisavakul, V., Buntaracha, B., Pharee, S., Apimeteetumrong, M., Sukwongs, Y. 1999. Effect of treatment with recombinant bovine somatotropin on responses to superovulatory treatment in swamp buffalo (Bubalus bubalis). Theriogenology 52:377-384. 
Souza, A.H., Carvalho, P.D., Rozner, A.E., Vieira, L.M., Hackbart, K.S., Bender, R.W., Dresch, A.R., Verstegen, J. P., Shaver, R.D., Wiltbank, M.C. 2014. Relationship between circulating anti-Müllerian hormone $(\mathrm{AMH})$ and superovulatory response of highproducing dairy cows. Journal of Dairy Science 98:169-178.

Steckler, T., Wang, J., Bartol, F., Roy, S.K., Padmanabhan, V. 2005. Fetal programming: prenatal testosterone treatment causes intrauterine growth retardation, reduces ovarian reserve and increases ovarian follicular recruitment. Endocrinology 146:3185-3193.

Steinfeld, H., Gerber, P., Wassenaar, T., Castel, V., Rosales, M., de Haan, C. 2006. Livestock's long shadow: environmental issues and options. Rome, Italy: FAO.

Stojsin-Carter,A., K. Mahboubi, N.N. Costa, D.J. Gillis, T.F. Carter, M.S. Neal, M.S. Miranda, O.M. Ohashi, L.A. Favetta, W.A. King. 2016. Systemic and local antimullerian hormone reflects differences in the reproduction potential of Zebu and European type cattle. Animal Reproduction Science 167:51-58.

Stouffer, R.L., F. Xu, D.M. Duffy. Molecular control of ovulation and luteinization in primate follicle. 2007. Frontiers in bioscience 12:297-307.

Streuli, I., de Mouzon, J., Paccolat, C., Chapron, C., Petignat, P., Irion, O.P., de Ziegler, D., 2014. AMH concentration is not related to effective time to pregnancy in women who conceive naturally. Reprodution Biomedical 28:216-224.

Sullivan M.W., Stewart-Akers, A., Krasnow, J.S., Berga, S.L., Zeleznik, A.J. 1999. Ovarian responses in women to recombinant follicle-stimulating hormone and luteinizing hormone (LH): a role for $\mathrm{LH}$ in the final stages of follicular maturation. Journal of Clinical Endocrinology and Metabolism 84:228-232.

Sunderland, S.J., Knight, P.G., Boland, M.P. Roche, J.F., Ireland, J.J. 1996. Alterations in intrafollicular levels of different molecular mass forms of inhibin during development of follicular and luteal phase dominant follicles in heifers. Biology of Reproduction 54:453462.

Takahasi, C., Fujito, A., Kazuka, M., Sugiyama, R., Ito, H., Isaka, K. 2008. Anti-Mullerian hormone substance from follicular fluid is positively associated with success in oocyte fertilization during in vitro fertilization. Fertlity and Sterility 89:586-591.

Taketo, T., Saeed, J., Manganaro, T., Takahashi, M., Dunahoe, P.K. 1993. Mulllerian inhibiting substance production associated with loss of oocytes and testicular differentiation in the transplanted mouse XX gonadal primordium. Biology of Reproduction 49:13-23.

Techakumphu, M., Sukwong, Y., Apimeteetumrong, M., Intaramongkol, S., Intaramongkol, J. 2000. Embryo and oocyte collection in Thai swamp buffalo (Bubalus bubalis) after superovulation. Thai Journal of Veterinary Medicine 30:33-42. 
Thomas, F.H., Telfer, E.E., Fraser, H.M. 2007. Expression of anti-Mullerian hormone protein during early follicular development in the primate ovary in vivo is influenced by suppression of gonadotropin secretion and inhibition of vascular endothelial growth factor. Endocrinology 148:2273-2281.

Thomasen, J.R., William, A., Egger-Danner, C., Sorensen, A.C. 2016. Reproductive technologies combine well with genomic selection in dairy breeding programs. Journal of Dairy Science 99:1331-1340.

Thornton P.K, Jones, P.G., Owiyo, T., Kruska, R.L., Herrero, M., Kristjanson, P., Notenbaert, A., Bekele. N., Omolo, A., Orindi, V., Otiende, B., Ochieng, A., Bhadwal, S., Anantram, K., Nair, S., Kumar, V., Kulkar, U. 2006. Mapping climate vulnerability and poverty in Africa. Report to the Department for International Development, ILRI Nairobi 00100, Kenya:171.

Thornton, P.K. 2010. Livestock production: recent trends, future prospects. Philosophical Transactions of the Royal Society B Biological Sciences 365:2853-2867.

Tremblay, J.L., Viger, R.S. 1999. Transcription factor GATA-4 enhances Mullerian inhibiting substance gene transcription through a direct interaction with the nuclear receptor SF-I. Molecular Endocrinology 13:1388-1401.

Tsakos, E., Tolikas, A., Daniilidis, A., Asimakopoulos, B. 2014. Predictive value of antimullerian hormone, follicle stimulating hormone and antral follicle count on the outcome of ovarian stimulation in women following GNRH antagonist protocol for IVF/ET. Archives of gynecology and obstetrics 290:1249-53.

Tsepelidis, S., Devreker, F., Demeestere, I., Flahaut, A., Gervy, C.H., Englert, Y. 2007. Stable serum levels of anti-Mullerian hormone during the menstrual cycle: a prospective study in normo-ovulatory women. Human Reproduction 22:1837-1840.

Turzillo, A.M., Fortune, J.E. 1993. Effects of suppressing plasma FSH on ovarian follicular dominance in cattle. Journal of Reproduction and Fertility 98:113-119.

Ueno, S., Kuroda, T., Maclaughlin, D.T., Ragin, R.C., Manganaro, T.F., Donahoe, P.K. 1989. Mullerian inhibiting substance in the adult rat ovary during various stages of the estrous cycle. Endocrinology 125:1060-1066.

Van Cappellen, W.A., Osman, P., Meijs-Roelofs, H.M. 1999. Model of antral follicle dynamics during the 5 day cycle in rats based on measurement of antral follicle inflow. Journal of Reproduction and Fertility 99:57-63. 
Van Rooij, I.A.J, Broekmans, F.J.M., Scheffer, G.J., Looman, C.W.N., Habbema, J.D.F., de Jong, F.H., Fauser, B.J.C.M., Themmen, A.P.N., te Velde, E.R. 2005. Serum Antimullerian Hormone Levels Best Reflect the Reproductive Decline with Age in Normal Women with Proven Fertility: A Longitudinal Study. Fertility and Sterility 83:979-987.

Van Rooij, I.A.J., Broekmans, F.J.M., te Velde, E.R., Fauser, B.C.J.M., Bancsi, L.F.J.M., de Jong, F.H., Themmen, A.P.N. 2002. Serum anti-mulllerian hormone levels: a novel measure of ovarian reserve. Human Reproduction 17:3065-3071.

Van Ty L., D. Chupin, M.A. Driancourt. 1989. Ovarian follicular populations in buffaloes and cows. Animal Reproduction Science 19:171-178.

Vassena R, G.P. Adams, R.J. Mapletoft, R.A. Pierson, J. Singh. 2003. Ultrasound image characteristics of ovarian follicles in relation to oocyte competence and follicular status in cattle. Animal Reproduction Science 76:25-41.

Vendola, K.A., Zhou,J., Adesanysa, O.O. 1998. Androgens stimulate early stages of follicular growth in the primate ovary. Journal of Clinical Investigation 101:2622-2629.

Vernunft, A., Schwerhoff, M., Viergutz, T., Diederich, M., Kuwer, A. 2015. Anti-Mullerian Hormone Levels in plasma of Holstein-Friesian heifers as a predictive parameter for ovum pick-up and embryo production outcomes. 2015. Journal of Reproduction and Development 61:74-79.

Vigier, R.S., Mertineit, C., Trasler, J.M., Nemer, M. 1998. Transcription factor GATA-4 is expressed in a sexually dimorphic pattern during mouse gonadal development and is a potent activator of the mullerian inhibiting substance promoter. Development 125:26652675.

Vishwanath, R. 2003. Artificial insemination: the state of the art. 2003. Theriogenology 59:571584.

Visser, J.A, Themmen, A.P.N. 2005. Anti-Müllerian hormone and folliculogenesis. Molecular and Cellular Endocrinology 234:81-86.

Visser, J.A., de Jong, F.H., Laven, J.S., Themmen, A.P. 2006. Anti-Müllerian hormone: a new marker for ovarian function. Reproduction: 131:1-9.

Visser, J.A., Hokken-Koelega, A.C., Zandwijken, G.R., Limacher, A., Ranke, M.B., Fluck, C.E. 2013. Anti-Mullerian Hormone levels in girls and adolescents with Turner syndrome are related to karyotype, pubertal development and growth hormone treatment. Human Reproduction 28:1899-1907. 
Visser, J.A., Themmen, A.P.N. 2001. Role of anti-Müllerian hormone and bone morphogenetic proteins in the regulation of FSH sensitivity. Molecular and Cellular Endocrinology, $382: 460-465$.

Visser, J.A., Themmen, A.P. 2014. Role of anti-Mullerian hormone and bone morphogenetic proteins in the regulation of FSH sensitivity. Molecular and Cellular Endocrinology 382:460-465.

Voutilainen, R., Miller, W.L. 1987. Human mullerian inhibitory factor messenger ribonucleic acid is hormonally regulated in the fetal testis and in adult granulosa cells. Molecular Endocrinology 1:604-608.

Warriach, H.M., D.M. McGill, R.D. Bush, P.C. Wynn, K.R. Chohan. 2015. A review of recent developments in buffalo Reproduction - A Review. Asian Australas. Journal of Animal Science 28:451-455.

Watanabe, K., Clarke, T.R., Lane, A.H., Wang, X., Donahoe, P.K. 2000. Endogenous expression of Mullerian inhibiting substance in early postnatal rat sertoli cells requires multiple steroidogenic factor 1 and GATA 4 binding sites. Proceedings of National Academy of Sciences USA 97:1624-1629.

Webb,R. Gauld, I.K., Draincourt, M.A. 1989. Morphological and functional characterization of large antral follicles in three breeds of sheep with different ovulation rates. Journal of Reproduction and Fertility 87:243-255.

Weenen, C., Laven, J.S., Von Bergh, A.R. 2004. Anti-Müllerian hormone expression pattern in the human ovary: potential implications for initial and cyclic follicle recruitment. Molecular Human Reproduction 10:77-83.

Willmott, N., Saunders, J., Bo, G.A., Palasz, A., Pierson, R.A., Maplesoft, R.J. 1990. The effect of FSH/LH ratio in pituitary extracts on superovulatory response in cow. Theriogenology $33: 347$.

Wilson, C., Clemente, N., Ehrenfels, C., Pepinsky, R., Josso, N., Vigier, B. 1993. Müllerian inhibiting substance requires its $\mathrm{N}$-terminal domain for maintenance of biological activity, a novel finding within the transforming growth-factor-beta superfamily. Molecular Endocrinology 7:247-257.

Wiweko, U. Anggraheni, E. Mansyur, T. Yuningsih, A.K. Harzief, G. Pratama, K. Sumapraja, M. Natadisastra, A. Hestiantoro. 2016. Serum AMH level predicts oocytes quality better than follicular fluid AMH. Asian Pacific Journal of Reproduction 5:361-364.

Wu, M., Wang, H., Murphy, B.D., Maplesoft, R.J. 1988. Superovlation with Follotropin: a dose trial. Theriogenology 29:332. 
Wunder, D.M., Bersinger, N.A., Yared, M., Kretschmer, R., Birkhauser, M.H. 2008. Statistically significant changes of anti-mullerian hormone and inhibin levels during the physiologic menstrual cycle in reproductive age women. Fertility and Steriltiy 89:927-933.

Xu, J., C.V. Bishop, M.S. Lawson, B.S. Park, F. Xu. 2016. Anti-Mullerian hormone promotes pre-antral follicle growth, but inhibits antral follicle maturation and dominant follicle selection in primates. Human Reproduction 31:1522-1530.

Yi, S.E., LaPolt, P.S., Yoon, B.S., Chen, J.Y., Lu, J.K., Lyons, K.M. 2001. The type 1 BMP receptor BmprIB is essential for female reproductive function. Proceedings National Academy of Sciences USA 98:7994-7999.

Yindee, M., M. Techakumphu, C. Lohachit, S. Sirivaidyapong, A.N. Chiangmai, H. RodriguezMartinez, G. C van der Weyden, B. Colenbrander. 2011. Follicular dynamics and oestrous detection in Thai postpartum swamp buffaloes (Bubalus Bubalis). Reproduction in Domestic Animals 46:91-96.

Young, J. M., A.N. Thompson, M. Curnow, C.M. Oldham. 2011. Whole-farm pro fi t and the optimum maternal liveweight pro fi le of Merino ewe flocks lambing in winter and spring are in fluenced by the effects of ewe nutrition on the progeny's survival and lifetime wool production. Animal Production Science 51:821-833.

Zec, I., Dubravka, T.M., Megla, Z.B., Zucak, I. 2011. Anti-müllerian hormone: A unique biochemical marker of gonadal development and fertility in humans. Biochemia Medica 21:219-230.

Zhang, Y.D., D.J. Johnston, S. Bolormaa, R.J. Hawken, B. Tier. 2013. Genomic selection for female reproduction in Australian tropically adapted beef cattle. Animal Production Science 54:16-24.

Zhu, J. J. OU, W. Xing, W. Li, W. ZHU. 2016. Anti-mullerian hormone, antral follicle count and follicle stimulating hormone for predicting the number of oocytes retrieved in IVF/ICSI cycles. Journal of Reproduction and Contraception 27(2):89-93.

Zicareli,L. 2007. Can we consider buffalo a non-precocious and hypofertile species? Italian Journal of Animal Science 6:143-154. 
Name

Parents

Date of Birth

Place of Birth
Adam Redhead

Dr. Carol Redhead

Iram Redhead

January $2^{\text {th }} 1983$

Port of Spain, Trinidad W.I.

Schools Attended

Rosary Boys Roman Catholic

1988-1994

Fatima College (CXC O Levels)

1994-1999

Fatima College (Cambridge A Levels

1999-2001

University of the West Indies, B.Sc.

2001-2004

University of the West Indies, M.Phil.

2008-2013

West Virginia University, Ph.D.

2012-2017 